Decentralisation of Administration, Policy Making and Forest Management in Ketapang District, West Kalimantan

Endriatmo Soetarto MT Felix Sitorus M Yusup Napiri 


\section{Decentralisation of Administration, Policy Making and Forest Management in Ketapang District, West Kalimantan}

Endriatmo Soetarto, MT Felix Sitorus and Yusup Napiri 
(c) 2001 by Center for International Forestry Research All rights reserved. Published in 2001

Printed by Subur Printing, Indonesia

\section{ISBN 979-8764-85-4}

\section{Published by}

Center for International Forestry Research

Mailing address: P.O. Box 6596 JKPWB, Jakarta 10065, Indonesia

Office address: JI. CIFOR, Situ Gede, Sindang Barang, Bogor Barat 16680, Indonesia

Tel.: +62 (251) 622622; Fax: +62 (251) 622100

E-mail: cifor@cgiar.org

Web site: http://www.cifor.cgiar.org 


\section{Decentralisation and Forests in Indonesia: An Overview of the Study}

ince early-2000, the Center for International Forestry

$\checkmark$ Research (CIFOR) has conducted research on the decentralisation of forest administration and policies affecting forests in Indonesia. This project has sought to document the real and anticipated impacts of decentralisation on forest management, forest community livelihoods, and economic development at the provincial and district levels. During the initial phase of this research, CIFOR conducted case studies in nine kabupaten or districts, in four provinces: Riau, East Kalimantan, Central Kalimantan, and West Kalimantan. These case studies were carried out in 2000, with follow up visits to some districts conducted in early 2001. As such, the findings presented in the present report and the companion case studies reflect the conditions and processes that existed in the study districts during the initial phase of Indonesia's decentralisation process.

The following reports have been produced by this project. The first of these represents a synthesis of the major findings from the nine case studies, accompanied by a historical analysis of forest administration and forestry sector development in Indonesia, and a discussion of the origins and legal-regulatory basis of the nation's ongoing decentralisation process. Each of the nine case studies is published as a separate report (with the exception of the study districts in Riau, which have been combined) in order to make the information contained therein more readily accessible to decision-makers involved in the decentralisation process. It is hoped that readers of the case studies will refer to the synthesis report in order to situate the specific case study findings in a broader historical and policy context.

During 2002, CIFOR will publish additional case studies from research on decentralisation and forests in West Kalimantan, South Sulawesi and Irian Jaya. CIFOR also plans to carry out follow-up research at several of the original case study districts, and will publish periodic findings from the sites.

\section{Acknowledgements and Disclaimer}

CIFOR gratefully acknowledges the financial support of the Australian Center for International Agricultural Research (ACIAR) and the United Kingdom's Department for International Development (DFID). The opinions expressed in this report are the views of the author(s) and do not necessarily represent the official policy of CIFOR. These opinions, likewise, do not represent the official policy of ACIAR or DFID or any other organization involved in funding, conducting or disseminating this study.

The authors acknowledge the assistance of a large number of persons in researching and preparing this study. In Riau, these included staff of government departments, in the areas of forestry, estate crops, planning, environment and finance, at both 
provincial and district levels. Academics from UNRI, together with members of NGOs, mostly Pekanbaru-based, provided fellowship and collegiality. We were also helped by staff from the two pulp and paper companies, from private timber and oil-palm concerns and from numbers of villagers in all districts. All Bupatis and temporary Bupatis in our study areas made themselves available to talk to us, for which we were grateful. We would especially like to thank Viator Butar-Butar in Pekanbaru, former director Ir Waldemar Sinaga and his staff at the Bukit Tigapuluh National Park Unit and the former staff of WWF Bukit Tigapuluh, especially Mangara Silalahi and Bobby Berlianto. In Jakarta many other people contributed, particularly the forest specialists from Manggala Wanabakti, while colleagues from CIFOR in Bogor, especially Chris Barr, provided stimulation and were patient through our drafts. Our fellow researchers, especially Anne Casson and John McCarthy, gave us the opportunity to exchange many useful ideas and experiences. 


\section{Editor's Preface}

\section{Overview of Indonesia's Decentralisation Process}

Since late-1998, Indonesia has undergone a process of rapid and far-reaching decentralisation. With this process, considerable degrees of administrative and regulatory authority have been transferred from the national government in Jakarta to the country's provincial and district governments. This transfer of authority has occurred across broad segments of the nation's economy and has sharply redefined the roles and responsibilities of government agencies at each level of the nation's administrative structure. With the locus of decision-making shifting decisively away from the national government, Indonesia's ongoing decentralisation process marks a dramatic break from the highly-centralized system of governance that characterized Suharto's New Order regime during the period 1966-1998.

To a significant extent, the process of decentralisation now occurring in Indonesia has been driven by the demands of provincial and district governments whose jurisdictions are rich in timber, petroleum, and other natural resources. Officials from resource-rich regions have long complained that the vast majority of the benefits from these assets have flowed away from their regions to the national government and to private sector companies closely associated with decision-makers in Jakarta. While the New Order government kept a tight lid on calls for greater regional autonomy and regional control over natural resource revenues, the post-Suharto government has not been able to ignore these demands. On the contrary, since 1998 the country's senior leadership has recognized that its ability to maintain Indonesia's integrity as a nation may ultimately depend on its capacity to strike a more equitable balance of power between the national government, on the one hand, and the provincial and district governments, on the other.

Over the last three years, the national government has issued several important pieces of legislation aimed at transferring authority to the provincial and district governments, and at allowing resource-rich regions to retain a larger share of the fiscal revenues generated within their jurisdictions. The most significant of these have been Law 22 on Regional Governance and Law 25 on Fiscal Balancing, both of which were issued in May 1999. Together, these laws provide the legal basis for regional autonomy, laying out a broad framework for the decentralisation of administrative and regulatory authority primarily to the district level. These laws have been supported by a variety of implementing regulations and sector-specific decentralisation laws, including Law 41 of 1999, a revised version of Indonesia's Basic Forestry Law, which outlines the division of administrative authority in the forestry sector under regional autonomy. 
In many parts of Indonesia, provincial and district officials acting in the spirit of regional autonomy have instituted reforms that extend well beyond the authority granted to them under the national government's decentralisation laws and regulations. Indeed, the formal decentralisation process has been driven, to a significant degree, not by policy decisions made at the national level but, rather, by decisions made by provincial and district level actors. This process has often been ad hoc in nature, with national policymakers frequently finding themselves in the position of having to react to fast-moving changes that have occurred in the provinces and districts. Far from being a well-planned and carefully-managed exercise in bureaucratic reorganization, the implementation of regional autonomy in Indonesia has been characterized by intense struggles among the different levels of government, each of which represents a competing set of political and economic interests. In this way, regional autonomy has stretched well beyond the formal decentralisation of administrative and regulatory authority; in practice, it also involves a significant, if largely informal and unplanned, devolution of power from the national government to its provincial and district-level counterparts.

The formal and informal processes of decentralisation have been accompanied by a wide-ranging set of governance and economic reforms, collectively known as reformasi, that are associated with Indonesia's transition away from Suharto's New Order regime. Broadly defined, reformasi refers to the transformation and dismantling of the policies, practices, and institutional structures through which the New Order leadership and a handful of well-connected conglomerates controlled the political and economic life of the country prior to Suharto's resignation in May 1998. While significant elements of the reformasi agenda coincide with the changes occurring under regional autonomy, these reform processes are also quite distinct. Whereas reformasi refers to a shift away from the constellation of interests and power structures that have supported a particular regime, decentralisation and regional autonomy refer to the transfer of authority from the national government to Indonesia's provincial and district governments.

\section{Decentralisation of Forest Administration}

The formal and informal processes of decentralisation that are now occurring in Indonesia have far-reaching implications for forest management and for the livelihoods of communities living in and around forested areas. On the positive side, experience from other countries suggests that decentralised systems of forest management often lead to more sustainable and equitable use of these resources, as decision-makers are physically located closer to where their policies will be implemented (Conyers 1981; Rondinelli, Nellis, and Cheema 1983). This proximity often brings with it improved understanding of the specific biophysical, social, and institutional conditions influencing forest management at the field level; better capacity to monitor the activities of forest user groups; and greater access to local knowledge about the management and utilization of forest resources - which are sometimes highly specific to particular social groups and/or ecosystems (Carney 1995). 
In addition, decentralised forest administration often allows for greater participation on the part of forest communities in policy decision-making processes, and more direct accountability of policymakers to peoples whose livelihoods depend on forests (Brandon and Wells 1992). Decentralisation also frequently implies a more equitable distribution of benefits from forest resources, as local communities and governments in forested regions are able to secure a greater portion of revenues from the extraction of timber and other forest products (Ascher 1995; Ostrom 1990).

In addition to providing opportunities for expanded equity and improved forest management, however, decentralisation also carries significant risks. In many countries, national governments have decentralised without first creating the necessary institutional capacity at the provincial or district levels to administer forests effectively (Rivera 1996). Often, national governments assign tasks to provincial and district governments without giving them adequate resources for carrying out these tasks. Most provincial and district governments lack essential technical skills and must look to other entities for advice, training, and technical information. In cases where local elites have been strong and/or traditionally marginalized groups have been unable to organize themselves, decentralisation has often strengthened pre-existing power relations, rather than promoting democratic decision-making processes (Utting 1993). Finally, even when elite groups do not dominate provincial and district governments, it is often that case that these governments have little interest in sustainable forest management.

\section{Indonesia's Forestry Sector}

The manner in which decentralisation affects forest management, community livelihoods, and economic development is of particular significance in Indonesia due to the scale and importance of the country's forest resources. Indonesia has the world's third largest tract of tropical forests, surpassed in area only by those of Brazil and Congo. In 1997, the country's total forest cover was officially estimated to be 100 million hectares (MOFEC, cited in World Bank 2001). It has been conservatively estimated that at least 20 million people depend on Indonesia's forests for the bulk of their livelihoods (Sunderlin, et al. 2000). Over the last three decades, the national government has allocated over 60 million hectares of forest to commercial logging companies, and Indonesia's forestry sector industries have long ranked second only to petroleum in terms of their contribution to GNP (Barr 2001). The forestry sector currently generates approximately US\$ 7 billion in annual revenues.

Well before the country's ongoing decentralisation process began in late-1998, Indonesia's forestry sector had entered a period of crisis. From the mid-1980s onward, deforestation is estimated to have occurred at a pace of 1.6 million hectares per year (Toha 2000). A major factor driving this high level of deforestation and associated forest degradation has been overcapacity in the nation's wood processing industries. Through the mid-1990s, Indonesia's sawnwood, plywood, and pulp industries are collectively estimated to have consumed 60-80 million cubic meters $\left(\mathrm{m}^{3}\right)$ of wood per year (Barr 2001; Scotland et al. 1998). Log consumption on this scale has stood well above the Indonesian government's own widely-cited sustainable timber harvest threshold 
of 25 million $\mathrm{m}^{3}$ per year. Moreover, with few effective regulatory structures in Indonesia's forestry sector, domestic demand for timber has resulted in large volumes of wood being harvested from illegal sources (ITFMP 1999). At the same time, a decline in the nation's HPH timber concession system, coupled with rapid expansion in oil palm and other forms of agroindustrial plantations, has meant that a growing portion of the nation's wood supply has been obtained through clearing of natural forest rather than selective harvesting at multiple-rotation timber concessions (Barr 2001).

\section{Scope and Methods of the Present Study}

The present report examines the preliminary effects of decentralisation of forest administration in the Ketapang district of West Kalimantan Province. This report presents the findings from one of nine district level case studies carried out during 2000 and early 2001 by the Center for International Forestry Research (CIFOR) in four provinces: Riau, East Kalimantan, Central Kalimantan, and West Kalimantan. The findings presented in these studies reflect the conditions and processes that existed in the study districts during the initial phase of Indonesia's decentralisation process.

Each of the case studies used a rapid appraisal methodology for gathering data at the district and provincial levels. For each case study, preliminary visits were made to the district and provincial capitals to establish initial contacts and to identify key issues. Second visits for data gathering were then carried out for periods of 10-14 days in each district, with shorter amounts of time in the provincial capitals. The collection of primary data involved semi-structured interviews with key informants, including: government officials; forest industry actors; members of communities living in and around forests; political party representatives; officers from the regional military and police force; informal district leaders; representatives from nongovernmental organizations (NGOs); university researchers; and individuals involved with donor agencies and development projects. Data collection also involved the review of primary and secondary documents, including: district and provincial laws and regulations; government statistics; regional news media articles; industry publications; research studies; and reports prepared by NGOs and donor agencies.

Each of these case studies is structured to focus on processes that have occurred at the district and, to a lesser extent, the provincial levels. To avoid repetition, more general information on the history of forest administration and forestry sector development in Indonesia, as well as significant national policy and legal-regulatory reforms associated with decentralisation, has been placed in an accompanying report which synthesizes the project's major findings (see Barr and Resosudarmo and 2001). Readers are encouraged to review the case studies in conjunction with this synthesis in order to appreciate the broader historical and policy contexts within which the district and provincial decentralisation processes are now occurring.

Christopher Barr and Ida Aju Pradnja Resosudarmo

Bogor, Indonesia 


\section{Glossary}

\begin{tabular}{|c|c|}
\hline APBD & Anggaran Pendapatan Belanja Daerah, Regional Budget \\
\hline Bappeda & $\begin{array}{l}\text { Badan Perencanaan Pembangunan Daerah, Regional Development Planning } \\
\text { Board }\end{array}$ \\
\hline BPKMD & $\begin{array}{l}\text { Badan Koordinasi Penanaman Modal Daerah, Regional Investment Coordinating } \\
\text { Board }\end{array}$ \\
\hline BPN & Badan Pertanahan Nasional, National Land Agency \\
\hline BPS & Balai Pusat Statistik, Central Bureau of Statistics \\
\hline BUMN & Badan Usaha Milik Negara, State Owned Enterprise \\
\hline $\mathrm{CPO}$ & Crude Palm Oil \\
\hline DAD & Dewan Adat Dayak, Dayak Adat Council \\
\hline DPRD & Dewan Perwakilan Rakyat Daerah, Provincial or District Legislative Assembly \\
\hline Dispenda & Dinas Pendapatan Daerah, District Revenues Office \\
\hline DR & Dana Reboisasi, Reforestation Fund \\
\hline GRDP & Gross Regional Domestic Product \\
\hline HGU & $\begin{array}{l}\text { Hak Guna Usaha, Land Use Permit issued by Ministry of Agrarian Affairs or National } \\
\text { Land Agency }\end{array}$ \\
\hline $\mathrm{HKm}$ & Hutan Kemasyarakatan, Community Forest \\
\hline $\mathrm{HPH}$ & Hak Pengusahaan Hutan, Commercial Forestry Concession. \\
\hline $\mathrm{HPHH}$ & Hak Pemungutan Hasil Hutan, Harvest Concession for Forest Products \\
\hline HPHKM & Hak Pengusahaan Hutan Kemasyarakatan, Community Forestry Concession \\
\hline HPHTI & Hak Pengusahaan Hutan Tanaman Industri, Timber Plantation Concession \\
\hline HTI & Hutan Tanaman Industri ,Timber Plantation \\
\hline $\mathrm{IHH}$ & Iuran Hasil Hutan, Forest Products Payment, now called PSDH \\
\hline IHPH & Iuran Hak Pengusahaan Hutan Forest Concession Royalty \\
\hline IHPHH & Iuran Hak Pemungutan Hasil Hutan Forest Product Harvest Concession Royalties \\
\hline IPK & Ijin Pemanfaatan Kayu, Timber Clearance Permit \\
\hline KKPA & Kredit Koperasi Primer untuk Anggota, Members' Primary Credit Cooperative \\
\hline $\mathrm{KPH}$ & Kesatuan Pemangkuan Hutan, Forest Management District \\
\hline KSDA & Konservasi Sumber Daya Alam, Natural Resource Conservation \\
\hline KSM & Kelompok Swadaya Masyarakat, self-help community group \\
\hline LIPI & Lembaga IImu Pengetahuan Indonesia, The Indonesian Institute of Sciences \\
\hline MoFEC & Ministry of Forestry and Estate Crops \\
\hline NES & Nucleus Estate Smallholder project \\
\hline NTFP & Non-Timber Forest Products \\
\hline PAD & Pendapatan Asli Daerah, Regionally Generated Revenues \\
\hline PBB & Pajak Bumi dan Bangunan, Land and Building Tax \\
\hline PBS & Perkebunan Besar Swasta, Private Large-Scale Plantation \\
\hline PBSA & Perkebunan Besar Swasta Asing, Foreign Large-Scale Plantation \\
\hline PIR & Perkebunan Inti Rakyat, People's Nucleus Plantations \\
\hline
\end{tabular}


PBSN

PSDH

RTRWK

RTRWP

RUTR

SAKB

SAKO

SKSHH

TGHK

TNGP

UPT
Private National Large-Scale Plantation

Provisi Sumber Daya Hutan, Forest Resource Rent Provision

Rencana Tata Ruang Wilayah Kabupaten, District Spatial Plan

Rencana Tata Ruang Wilayah Propinsi, Provincial Spatial Plan

Rencana Umum Tata Ruang, General Spatial Plan

Surat Angkutan Kayu Bulat,Permit to Transport Timber

Surat Angkutan Kayu Olahan, Permit to transport Processed Wood Products

Surat Keterangan Sahnya Hasil Hutan, Permit to Transport Timber and Other Forest Products

Tata Guna Hutan Kesepakatan, Forest Land Use Consensus

Taman Nasional Gunung Palung, Gunung Palung National ParkUPP Unit

Pelayanan Pembangunan, Development Service Unit

Unit Pelaksana Teknis, Technical Executive Unit 


\section{Table of Contents}

Decentralisation and Forest in Indonesia: An Overview of the Study iii

Editor's Preface v

Glossary $\quad$ ix

Abstract xiii

1. Profile of the Research Area 1

1.1 Province of West Kalimantan 1

1.1.1 Geography and people 1

$\begin{array}{ll}1.1 .2 \text { Land use } & 1\end{array}$

1.1.3 Economy and finance 3

1.2 Profile of the Ketapang District 5

1.2.1 Geography and people 5

$\begin{array}{ll}1.2 .2 \text { Land use } & 6\end{array}$

$\begin{array}{ll}1.2 .3 \text { Economy and finance } & 6\end{array}$

2. Decentralisation of Forestry and Plantation Policies and

Administration in West Kalimantan 8

2.1 Present State of Forestry and Plantations 8

2.1.1 Stakeholders and their roles 8

2.1.2 Forestry and plantations 11

2.1.3 The economic role of the forestry and plantation sector 14

2.2 Decentralisation of the Forestry and Plantations Sector 14

2.2.1 Conflicts between stakeholders 14

$\begin{array}{ll}2.2 .2 & 17 \text { Indicators of decentralisation } \\ \end{array}$

$\begin{array}{lll}2.2 .3 & \text { The provincial government's response to } \\ \text { the decentralisation process } & 18\end{array}$

3. Decentralisation of Forestry and Plantation Policies and Administration in Ketapang District 19

3.1 Forestry and Plantation 19

3.1.1 Stakeholders and their roles $\quad 19$

$\begin{array}{lll}3.1 .2 & \text { Forestry and plantations } & 21\end{array}$

3.1.3 Contributions to the regional economy 23

3.2 Decentralisation of the Forestry and Estate Crops Sector 25

3.2.1 Conflicts between stakeholders 25

3.2.2 The different forms of decentralisation 28

3.3 Response to the Issue of Decentralisation 33

$\begin{array}{lll}3.3 .1 & \text { Local government response } & 33\end{array}$

3.3.2 Response of the private sector 34 
4. Decentralisation in Three Areas: Adat Communities, Plantations and The Gunung Palung National Park 36

4.1 Dayak Adat Communities 36

4.1.1 Dayak adat communities and their land 36

4.1.2 HPH concessions and illegal logging 37

4.1.3 Participatory mapping 38

4.1.4 Forest product collection rights 38

4.2 Agro-industrial Plantations 39

4.2.1 Plantation investment systems 39

4.2.2 Location licences for plantations 41

4.2.3 Oil palm versus rubber 41

4.2.4 Plantations as a source of local revenues $\quad 42$

4.3 Management of the Gunung Palung National Park 42

4.3.1 Gunung Palung National Park 42

4.3.2 Management and activities in the TNGP area 43

4.3.3 Responses to the TNGP management activities 43

5. Conclusions 47

5.1 De Facto Decentralisation $\quad 47$

5.1.1 Illegal logging 47

5.1.2 Harvest Concession for Forest Products (HPHH) 47

5.1.3 Plantation investment procedures 48

5.1.4 Local community autonomy 48

5.2 Linking Decentralisation and Forest Conservation 48

5.3 Empowerment of Local People 48

5.4 The Role of the Private Sector 49

5.5 Land Use Planning 49

5.6 Financing Local Development 49

5.7 Human Resources for Decentralisation 49

5.8 Non-forest Resources (Mining) 50

5.9 Protected Areas 50

6. Endnotes 51

7. References 53 


\section{Abstract}

This study examines the preliminary impacts of Indonesia's decentralization process on the administration and management of forest resources in Ketapang District, West Kalimantan. The case study is based on field work carried out in mid-2000, using a rapid appraisal methodology. The report covers the impacts of decentralization in three areas, in particular: customary adat communities, oil palm and rubber plantations, and conservation issues related to Gunung Palang National Park. In each of these areas, the authors examine struggles among competing interest groups that have arisen under decentralization. The study finds that with the shift of administrative authority to the district level, the district government in Ketapang took measures to generate local sources of revenues by issuing large numbers of small-scale timber extraction permits and to 'legalize' the transport of timber that had otherwise been harvested illegally. The study also finds that the very limited flow of formal revenues form the Gunung Palang National Park to the district government has encouraged an escalation of illegal logging within the park's boundaries. The authors recommend that the Ketapang District government become more involved in administering the national park to ensure that economic interests of both the district government and local communities are accomodated in the park's management. 


\section{PROFILE OF THE RESEARCH AREA}

\subsection{PROVINCE OF WEST KALIMANTAN}

\subsubsection{Geography and people}

West Kalimantan is the fourth largest province in Indonesia, covering 146,807 square kilometers $\left(\mathrm{km}^{2}\right)(7.53 \%$ of the area of Indonesia). When first formed in 1956, this province consisted of six districts (Pontianak, Sambas, Sanggau, Ketapang, Sintang, Kapuas Hulu) and one municipality (the city of Pontianak). In 1999, two new districts were added: Landak (an offshoot from the Pontianak district) and Bengkayang (originally part of Sambas). Mainland West Kalimantan, bordered in the north by the Malaysian state of Sarawak, consists mostly of lowlands with a few hills, while the marine area contains scores of islands. Vegetation types include coastal vegetation, mangroves, swamp land and upland rain forest. The soils of West Kalimantan are predominantly pure or composite yellow red podzol. The hydrological regime is dominated by the Kapuas River, the longest in Indonesia $(1,086 \mathrm{~km})$, and Sentarum Lake, with an area of 117,500 hectares. There are hundreds of rivers in West Kalimantan, all originating in either the Kapuas Hulu Range (Kalingkang) or the Schwaner Range.

West Kalimantan is sparsely populated. In 1998, the province had $3,826,800$ people, with an average population of 26 people $/ \mathrm{km}^{2}$. The population is unevenly distributed among the districts. Outside the municipality of Pontianak $\left(4,364\right.$ people $\left./ \mathrm{km}^{2}\right)$, the most densely populated district is Sambas (72 people $\left./ \mathrm{km}^{2}\right)$, and the least dense is Kapuas Hulu ( 5 people $/ \mathrm{km}^{2}$ ). Coastal regions are home to two-thirds of the population with a population density of 75 people $/ \mathrm{km}^{2}$, while inland areas have only 6 people/ $\mathrm{km}^{2}$ (BPS 1998). The 1998 National Socioeconomic Survey (Susenas) showed that, of the 1,787,677 West Kalimantan residents classified as of working age, $94.63 \%$ were working. This workforce was dominated by the 10-24 age group and 60\% of the working-age population was employed in agriculture (age 14, and 18 for heavy labour).

\subsubsection{Land use}

The development of West Kalimantan's economy has traditionally been based on the utilisation of its natural resources, particularly its forests. As development continues, the demand for land is no longer limited to the forestry sector, and the requirements of a number of other growth sectors become strategically important in the allocation of land. With this in mind, the Directorate General of Forestry, supervised by the Ministry of Agriculture classified land use for the allocation of sectoral interests based on land use functions. This national system, developed in 1981, was called Forest Land Use Consensus (TGHK). ${ }^{1}$

The TGHK planning process was conducted at the macro level and was heavily dominated by forestry sector interests. This is reflected in the definitions of utilisation functions: other sectors were only able to use land classified as 'land with other uses' or 'conversion forest' area. The TGHK was also heavily centralist, paying inadequate attention to actual land use in the field. Moreover, inaccuracies in the databases used to determine forest limits caused a number of overlaps in area functions. In 1998, The Regional Development Planning Board 


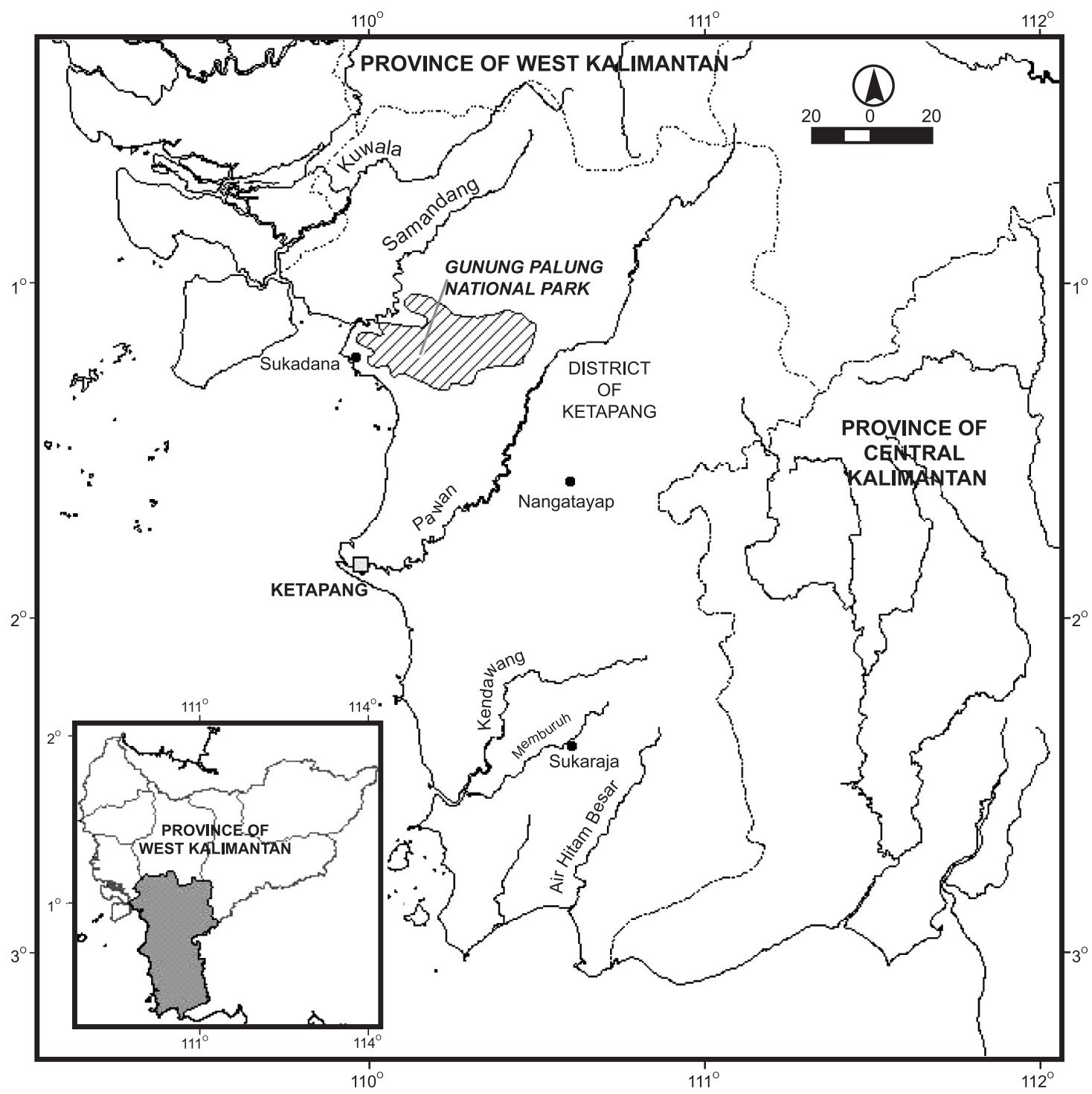

(Badan Perencanaan Pembangunan Daerah or Bappeda) identified the following overlaps:

- 1,294,035.5 ha of Commercial Forestry Concession (HPH) area was in a protected zone $^{2}$

- 29,687.5 ha of the area recommended for plantations was a conservation zone

- 44,371 ha of Timber Plantation (HTI) area was in conservation zone

This situation arose partly because the TGHK was decreed in 1982 and HPH allocations had commenced in 1967. To resolve such inconsistencies, although somewhat belatedly, the central government attempted to modify land allocations by issuing Land Use Law No. 24/1992. Based on this law, West Kalimantan's provincial government drew up a Provincial Spatial Plan (RTRWP). ${ }^{3}$ After a two-year struggle, principally between the provincial government and the Ministry of Forestry, this RTRWP was finally endorsed by the Minister of Home Affairs, to be effective until $2008 .^{4}$

The next step in improving land use planning was to resolve differences between the Ministry of Forestry's TGHK and the provincial government's RTRWP in terms of land use 
Table 1. Land classifications in West Kalimantan under TGHK and RTRWP

\begin{tabular}{lrc}
\hline Land Classification & \multicolumn{1}{c}{$\begin{array}{c}\text { RTRWP } \\
\text { (ha) }\end{array}$} & $\begin{array}{c}\text { TGHK } \\
\text { (ha) }\end{array}$ \\
\hline 1. Protected Area & 153,257 & \\
$\quad$ Nature Reserve & $1,252,859$ & $1,336,750$ \\
National Park & 29,310 & \\
Natural Tourism Forest & $2,161,465$ & $2,047,125$ \\
Protected Forest & 124,380 & \\
Protected Peat Forest & 69,200 & \\
Mangrove Forest & 22,215 & $3,383,875$ \\
Marine Park & $3,812,686$ & \\
& & $2,988,750$ \\
Sub Total & $2,408,775$ & $1,323,000$ \\
\hline 2. Cultivation Area & $2,255,010$ & $1,508,750$ \\
Limited Production Forest & 514,350 & $5,476,325$ \\
Production Forest & $5,689,825$ & $11,296,825$ \\
Conversion Forest & & $\mathbf{1 4 , 6 8 0 , 7 0 0}$ \\
Land with other Use & $10,867,960$ & \\
\hline Sub Total & $\mathbf{1 4 , 6 8 0 , 7 0 0}$ &
\end{tabular}

Sources: RTRWP: West Kalimantan Forestry Office (1999), RTRWP based on Regional Regulation of the Province of West Kalimantan No. 1/1995.

TGHK: West Kalimantan Regional Forestry Office.

functions (Table 1). In this way only one set of guidelines would govern allocations of land for utilisation. The "harmonised map" (peta padu serasi) was endorsed by the Governor of West Kalimantan in $1999^{5}$ and was printed by the provincial office of the National Land Agency (BPN). However, the process of harmonisation between the TGHK and the RTRWP plans remains incomplete. The allocation of areas classified as Forest Estate (Kawasan Hutan) for non-forest use is still an issue of contention between the national and provincial governments.

\subsubsection{Economy and finance}

Agriculture is a strategic sector for West Kalimantan's economy and people. Its average annual contribution to the Province's Gross Regional Domestic Product (GRDP) from 1993 to 1998 was $24 \%$. Over the same period, contributions from the forestry sub-sector, which is included in the agriculture sector, were an average $8 \%$ per year. Other sectors that play a significant role in the regional economy are industry and trade, although the contributions from these two sectors registered a decline during the 1993-1998 period (Table 2). Mining is still only a small contributor to the GRDP, with production based on C-classified (mineral classified as nonstrategic and non-vital by Law No.11/1967 on Basic Principles on Mining) extractive.

Between 1993 and 1996 West Kalimantan's economic performance was satisfactory. The economy grew by $10.75 \%$ in 1996 , before slowing in 1997 to $7.53 \%$ as a result of a combination of factors including a long dry season, forest fires and the eruption of social conflicts in 1996. This deterioration continued into 1998 with the economy actually contracting by $5.16 \%$ as a result of Indonesia's national financial crisis. The sector that showed the sharpest decline was the processing industry; this can be attributed to the high cost of raw materials and reduced purchasing power. In 1999 the rate of economic growth started to recover, with growth of $2.01 \%$ (Accountability Report of the Governor of West Kalimantan 2000).

West Kalimantan's GRDP reached Rp 15.7 trillion 
Table 2. West Kalimantan GRDP by sector, 1993-1998 (percentage)

\begin{tabular}{lrrrrrr}
\hline Sector & \multicolumn{7}{c}{ Contribution (\%) } \\
& \multicolumn{1}{c}{1993} & $\mathbf{1 9 9 4}$ & $\mathbf{1 9 9 5}$ & $\mathbf{1 9 9 6}$ & $\mathbf{1 9 9 7}$ & $\mathbf{1 9 9 8}$ \\
\hline Agriculture & 25.08 & 24.23 & 23.80 & 23.21 & 23.13 & 24.13 \\
Mining & 0.99 & 1.18 & 1.27 & 1.34 & 1.41 & 1.46 \\
Industry & 20.04 & 20.30 & 20.00 & 19.61 & 19.42 & 18.57 \\
Electricity & 0.59 & 0.63 & 0.69 & 0.74 & 0.78 & 0.86 \\
Buildings & 5.64 & 5.82 & 6.28 & 6.52 & 6.46 & 6.26 \\
Trade & 21.13 & 21.05 & 21.10 & 20.72 & 20.26 & 19.41 \\
Transportation & 9.94 & 10.23 & 10.13 & 10.17 & 10.26 & 10.68 \\
Finance & 7.58 & 6.79 & 6.76 & 6.07 & 7.06 & 7.07 \\
Services & 9.01 & 9.77 & 9.97 & 10.68 & 11.22 & 11.55 \\
& & & & & & \\
\hline GRDP & 100 & 100 & 100 & 100 & 100 & 100 \\
\hline
\end{tabular}

Source: Bappeda and BPS (1999).

(at current prices) in 1998, compared to only Rp 5.15 trillion in 1993. Per capita GRDP also rose, from Rp 1.5 million in 1993 to $\mathrm{Rp} 3.8$ million in 1998. However, the growth in per capita GRDP was not felt in real terms, as there was a simultaneous - and significant - rise in inflation. Between 1993 and 1997 the average annual inflation rate was $8.77 \%$; and following the onset of the economic crisis, in 1998 it reached $78.85 \%$ (Bappeda and BPS 1998).

The provincial government's administrative, development and public service activities are detailed in the Provincial Budget (APBD). The target for West Kalimantan's APBD for the 1999/
2000 budget year was Rp 256.5 billion (Table 3 ). ${ }^{6}$ Under the centralised finance system, the main source of regional revenue came from central government allocations, whether directly or through sectoral departments.

By the end of March 2000, total revenue amounted to $\mathrm{Rp} 254.6$ billion, with local revenues ${ }^{7}$ contributing approximately $\mathrm{Rp} 54.1$ billion (or roughly $20 \%$ ). Revenue from the production sectors is included in central government allocations because this was considered national revenue until 2000 , with the regions merely receiving a share of these profits. For example, revenues from the forestry sector, in the form of the Reforestation Fund

Table 3. West Kalimantan Regional Budget (target and realised), 1999/2000

\begin{tabular}{lcr}
\hline Item & $\begin{array}{c}\text { Target } \\
\text { (Rp million) }\end{array}$ & $\begin{array}{c}\text { Realised } \\
\text { (Rp million) }\end{array}$ \\
\hline I. Revenues & $\mathbf{2 5 6 , 4 7 9 . 1 9}$ & $\mathbf{2 5 4 , 6 3 0 . 8 9}$ \\
$\quad$ Carried over from 1998/99 budget & $18,579.49$ & $18,579.49$ \\
Local revenues & $50,746.27$ & $54,070.29$ \\
$\quad$ Allocations from central government and & $175,285.42$ & $170,131.10$ \\
$\quad$ other higher government agencies & & \\
\hline Total local government loans & $11,850.00$ & $11,850.00$ \\
\hline II. Expenditures & $\mathbf{2 5 6 , 4 7 9 . 1 9}$ & $\mathbf{2 3 0 , 1 4 9 . 7 8}$ \\
$\quad$ Routine expenditures & $107,622.69$ & $96,211.57$ \\
$\quad$ Development expenditures & $148,856.50$ & $133,938.21$ \\
\hline
\end{tabular}

Source: Accountability Report of the Governor of West Kalimantan (2000). 
(DR), Commercial Forestry Concession (HPH) fees and Forest Resource Rent Provision (PSDH) went into the central treasury. Prior to the introduction of Law No. 25/1999 on fiscal balancing between Indonesia's central and regional governments, the regions received only a share of the $\mathrm{PSDH}$ revenues: $30 \%$ to the province and $15 \%$ to the district.

\subsection{PROFILE OF THE KETAPANG DISTRICT}

\subsubsection{Geography and people}

Located in the southern part of the province, with an area of $35,809 \mathrm{~km}^{2}$, Ketapang is the largest district in West Kalimantan. Much of its area $(52.14 \%)$ is flat, with a gradient of less than $2 \%$, particularly along the coast, which stretches north to south. Part of this is swampland with potential for rice cultivation. Meanwhile, the inland area consists of plains, hilly and mountainous areas, including the Schwaner Range (RePProT 1987). Much of the area is still covered in primary forest while the rest is under plantations and agricultural cultivation (Table 5). The upland regions are the sources of the Melawi, Kapuas and other rivers that flow through the district. Ketapang is divided into 12 watershed divisions.

The Ketapang district is not densely populated, with only 11 people $/ \mathrm{km}^{2}$ in 1998 , when there were 403,010 residents. The sub district with the highest density is Matan Hilir Utara (49 people $/ \mathrm{km}^{2}$ ) while the most sparsely populated is Sandai (4 people/ $\mathrm{km}^{2}$ ). Population growth in Ketapang can be attributed both to natural increase and to transmigration programmes in a number of sub districts (Sandai, Tumbang Titi, Marau, Nanga Tayap and Simpang Hilir) since 1990/1991. The actual number of transmigrants arriving in Ketapang between 1990 and 1999 was 23,118 households or 73,965 people (Ministry of Transmigration 1998). In addition, spontaneous in-migration occurred in the form of newcomers working in the forestry and plantation sectors. The Ketapang district has a relatively young population, with $41.5 \%$ of the people aged under 15 . Because only $48.9 \%$ are of

Table 4. RTRWK, RTRWP and TGHK land classifications, Ketapang District, 1999

\begin{tabular}{lccc}
\hline Land Classification & $\begin{array}{c}\text { RTRWK } \\
\text { (ha) }\end{array}$ & $\begin{array}{c}\text { RTRWP } \\
\text { (ha) }\end{array}$ & $\begin{array}{c}\text { TGHK } \\
\text { (ha) }\end{array}$ \\
\hline $\begin{array}{l}\text { 1. Protected Area } \\
\text { Nature reserve/ National park/ }\end{array}$ & 269,182 & 292,611 & 292,611 \\
& & & \\
Natural tourism forest & 495,411 & 312,629 & 312,629 \\
$\quad \begin{array}{l}\text { Protected forest } \\
\text { Protected moss forest }\end{array}$ & 63,856 & 67,347 & \\
$\quad$ Mangrove forest & 273 & & \\
$\quad$ Marine park & 26,202 & & \\
\hline Sub Total & $\mathbf{8 5 9 , 0 6 8}$ & $\mathbf{6 7 2 , 5 8 7}$ & $\mathbf{6 0 5 , 2 4 0}$ \\
\hline 2. Cultivation Area & & & \\
$\quad$ Production forest & 548,011 & 621,345 & 621,305 \\
$\quad$ Limited production forest & 622,145 & 870,360 & 870,360 \\
$\quad$ Conversion forest & 337,349 & 239,659 & 239,659 \\
$\quad$ Land for other uses & $1,214,327$ & $1,176,949$ & $1,244,336$ \\
\hline Sub Total & $\mathbf{2 , 7 2 1 , 8 3 2}$ & $\mathbf{2 , 9 0 8 , 3 1 3}$ & $\mathbf{2 , 9 7 6 , 6 6 0}$ \\
\hline TOTAL & $\mathbf{3 , 5 8 0 , 9 0 0}$ & $\mathbf{3 , 5 8 0 , 9 0 0}$ & $\mathbf{3 , 5 8 0 , 9 0 0}$ \\
\hline
\end{tabular}

Sources : RTRWP: West Kalimantan Provincial Bappeda (1999). RTRWK: Ketapang District-level Bappeda (1999). TGHK: Provincial Forestry Office (1999). 
Table 5. Land Use in the Ketapang District, 1997

\begin{tabular}{lcc}
\hline Land Use Type & $\begin{array}{c}\text { Area } \\
\text { (ha) }\end{array}$ & (\%) \\
\hline Inhabited & 38,400 & 1.07 \\
Rubber plantations & 67,500 & 1.89 \\
Palm plantations & 13,500 & 0.38 \\
Oil palm plantations & 58,200 & 1.63 \\
Rice cultivation & 68,600 & 1.92 \\
Cultivated fields & 67,700 & 1.89 \\
Brushwood & 165,000 & 4.61 \\
Secondary forest & 830,300 & 23.19 \\
Dense forest & $2,271,700$ & 63.44 \\
\hline Total & $\mathbf{3 , 5 8 0 , 9 0 0}$ & $\mathbf{1 0 0 . 0 0}$ \\
\hline
\end{tabular}

Source: Ketapang District Bappeda (1999).

productive working age, these dependants impose a significant burden on the workers. A high proportion $(66.8 \%)$ of working-age people are employed in the agricultural sector, which includes forestry, and the rest are evenly distributed between trade, services and industry.

\subsubsection{Land use}

The land use plan for the Ketapang district reflects the different economic priorities of the regional and central levels of government. There are three versions of the planned land use functions in the district which vary based on the following factors:

- Forest Land Use Consensus or TGHK (from the central Ministry of Forestry and Estate Crops);

- The Provincial Spatial Plan or RTRWP; and

- The District Spatial Plan or RTRWK.

Law No. 24/1992 defines a land use hierarchy wherein the RTRWK should be a refinement of the RTRWP, with greater detail and precision at the district level. However, the three land use plans show discrepancies in distribution based on the classification of land functions (Table 4).

The major discrepancies appear for protected forest, conversion forest and land for other uses. In the district plan, the area of protected forest is 182,782 ha greater than that in the provincial and central government plans. This is not the result of the district placing a higher priority on conservation and protection, but is caused by the use of different criteria for defining protected areas, as well as changes to actual conditions on the ground. ${ }^{8}$
The areas designated for cultivated land, particularly under the classifications of conversion forest and land for other uses, are again greater in the RTRWK than in TGHK and the RTRWP. This reflects the desire of the Ketapang government to increase the area of land that it can control and manage itself for the purpose of regional economic development. These land classifications are more likely to generate local revenues than production forest. An increase in the area classified as conversion forest and land for other uses will reduce the area available for production forest. In 1997, forest actually covered most of the Ketapang district, including dense forest (63.4\%) and secondary forest (23.2\%) (Bappeda Ketapang district 1999). Forested areas will therefore have to be used by the district to allocate land for non-forestry purposes.

\subsubsection{Economy and finance}

Like much of the province, Ketapang's economy is dominated by the agricultural sector, which includes forestry. This sector contributed an average of $25 \%$ each year over the period 1994-1998 (Table 6). Thereafter, the contribution from agriculture declined slightly (26\% in 1994 became $24 \%$ in 1998), partly because of increased contributions from other sectors such as industry, trade and transportation. This pattern of economic development is different to what happened at the provincial level, where increased contributions were recorded in the wholesale trade and inland waterways and sea transportation subsectors. Ketapang's strategic position, enabling direct sea links with Java, supports the movement of people 
Table 6. Ketapang District GRDP by sector, 1994-98 (percentage)

\begin{tabular}{lrrrrr}
\hline Sector & $\mathbf{1 9 9 4}$ & $\mathbf{1 9 9 5}$ & $\mathbf{1 9 9 6}$ & $\mathbf{1 9 9 7}$ & $\mathbf{1 9 9 8}$ \\
\hline Agriculture & 26.34 & 25.97 & 25.16 & 24.88 & 23.72 \\
Mining & 4.74 & 6.04 & 1.34 & 6.13 & 4.61 \\
Industry & 22.00 & 21.72 & 20.37 & 19.75 & 20.61 \\
Electricity, Use & 0.20 & 0.26 & 0.31 & 0.35 & 0.38 \\
Buildings & 2.99 & 2.95 & 3.45 & 3.41 & 3.47 \\
Trade & 21.54 & 20.96 & 21.15 & 20.65 & 21.72 \\
Transportation & 13.96 & 13.60 & 13.95 & 14.80 & 15.65 \\
Finance & 4.20 & 4.59 & 4.88 & 5.17 & 5.22 \\
Services & 4.04 & 3.90 & 4.24 & 4.86 & 5.91 \\
\hline GRDP & 100 & 100 & 100 & 100 & 100 \\
\hline
\end{tabular}

Source: BPS (1999).

and goods in interregional trade. This growth is closely related to the expanding wood processing industry and the transport of processed wood to Java.

The economic crisis and the prolonged dry season of 1997-1998 had considerable adverse effects on economic growth in Ketapang district. From 1994 to 1996, economic growth increased each year, reaching its highest figure $(10.15 \%)$ in 1996. In 1997, when the national economic crisis started, this growth rate dropped to $7.47 \%$ and reached its lowest point in 1998 when the economy contracted by $2.92 \%$. Inflation over the same period rose from $12.11 \%$ in 1997 to $26.57 \%$ in 1998 (based on the GRDP figures); in 1994 it had been $8.14 \%$.

The greatest contribution to the district's revenue in 1997-1998 came from the central government, higher agency donations and aid (41.23\%) (Table 7). District-generated revenues (PAD) provided the lowest contribution at only $1.89 \%$. This clearly demonstrates the local government's limited capacity to deal independently with its own development, resulting in total dependency on the central government and the private sector for investment.

Table 7. Realised Regional Budget (APBD) of Ketapang District 1997-1998

\begin{tabular}{lc}
\hline Item & Total \\
& (Rp million) \\
\hline I. Revenues & $\mathbf{6 5 , 3 5 6 . 0 0}$ \\
Carried over from previous year's budget & $1,480.00$ \\
Local revenues & $1,238.00$ \\
Tax/non-tax allocations & $11,812.00$ \\
Government, higher agency donations and aid & $26,946.00$ \\
Development revenues & $17,780.00$ \\
Cash and accounting matters & $6,100.00$ \\
\hline II. Expenditures & $\mathbf{5 9 , 1 8 1 . 0 0}$ \\
Routine expenditures & $35,993.00$ \\
Development expenditures & $17,088.00$ \\
Cash and accounting matters & $6,100.00$ \\
\hline
\end{tabular}

Source: Ketapang BPS (1999). 


\subsection{PRESENT STATE OF FORESTRY AND PLANTATIONS}

\subsubsection{Stakeholders and their roles}

\subsubsection{Government agencies}

In a legal and formal sense, level I, or provincial governments (including the government of West Kalimantan) have wide-ranging authority over forestry activities, including the exploitation, sale and distribution of forest products, and the protection of forest resources. This authority is based on Government Regulation No. 64/1957, which mentions 'the transfer of some forestry matters to level I swatantra ${ }^{9}$ regions'. However, the Basic Forestry Law of 1967 and Government Regulation No. $21 / 1970^{10}$ revoked part of this authority. While the provincial government did still have some authority, this was generally limited to an auxiliary role. Since 1970, the provincial government of West Kalimantan has lost authority over the management of strategic activities in the forestry sector, despite the fact that the forests, with all their riches, have considerable potential to stimulate the provincial economy.

Law 5/1974 on the Basic Principles underlying Regional Administration were highly centralist and greatly empowered the central government. This was also the case with the Minister of Home Affairs' Decree No. 363/1977 on the Guidelines for the Establishment, Organisational Structure and Working Procedures of Local Government Offices, which strengthened the central government's supremacy over local government.

As a result of Decree No. 363/1977, the functions of the Forestry Office (Dinas Kehutanan) established by the provincial government ${ }^{11}$ had to be brought into line with the demands of central government. The institutional authority of this office was, in practice, restricted to the role set out in the provisions of the decree. Thus, from the local perspective, this regionally established forestry-sector administrative institution was ineffectual, in the sense that it could only act under instructions from the center and had little independent authority. At the district level, the Dinas Kehutanan was only established in 1986. There are now nine such district-level forestry offices referred to as Forest Management Districts (Kesatuan Pemangkuan Hutan or KPH) or their equivalents, with the status of 'branch offices'. ${ }^{12}$ These KPHs had little real authority, despite being directly involved with all matters in the field; and to a significant extent, their operations were also restricted by their limited facilities.

Regional Regulation No. 8/1980 declares 'that the function of the Forestry Office is to be the executive agency of the Level I Government of the Province of West Kalimantan which carries out work in the forestry sector bearing in mind technical directives from the Minister'. This reinforces the role of the office as a regional institution acting merely as an 'assistant' to the central government. This situation is compounded by the composition of the Dinas Kehutanan budget, in which $80 \%$ of income constitutes money allocated from the centre.

Another area where the central government intervenes was in the appointment of the head of the Forestry office. A provincial Bappeda official explained that, although Dinas Kehutanan was indeed an agency under the provincial government, it was effectively still under central government's 
control. Effective management is difficult (in practice) even when simply trying to gain access to accurate data. These problems appear to be related to the fact that it was an organisational unit with a relatively high concentration of financial resources, suggesting that particular interests were being protected.

Strong centralised intervention in forestry matters became more evident with the establishment of the Regional Office (Kantor Wilayah, or Kanwil) by the Ministry of Forestry. In theory, the Kanwil was originally intended to assist in forestry matters, particularly in improving economic efficiency. In reality, with almost identical and overlapping functions to the Provincial Forestry Office (Dinas Kehutanan), the Kanwil not only diminished the functions of the Provincial Forestry Office, but also actually created further red tape.

Even greater central control came with the formation of Technical Executive Units (UPT) ${ }^{13}$, responsible to the Kanwil, to manage specific forestry sectors. These included the following:

- Area VI Forest Exploitation Management Unit (BEH): to supervise the exploitation of forests; located in Pontianak.

- Area III Forest Inventory and Mapping Management Unit (Biphut): to handle inventory and mapping; located in Pontianak and assisted by three sub-Biphuts in Pontianak, Ketapang and Sintang.

- Kapuas Reforestation and Land Conservation Management Unit (BRLKT): to rehabilitate land outside forest areas, located in Pontianak.

- Natural Resource Conservation (KSDA) Unit: previously under the Director General of Nature Protection and Conservation; located in Pontianak and assisted by three subsections in Sintang, Kapuas Hulu and Ketapang.

- West Kalimantan National Parks Unit to manage the province's four national parks: Gunung Palung, Bukit Baka-Bukit Raya, Bentuang Karimun and Danau Sentarum. ${ }^{14}$

It is clear from the authority, organisational structure, personnel support and facilities, that the central government's priorities for forest management are focused on exploiting forest products rather than on conserving and rehabilitating forest areas. The Head of KSDA noted that an operational conservation area in West Kalimantan that is almost as large as the island of Java is managed by a sub-UPT with relatively lowlevel staff ${ }^{15}$, while the sector exploiting forest products is managed by an UPT with more senior officials. As a consequence, the small Natural Resource Conservation Unit has had little success in handling the frequent cases of illegal logging in the Kendawangan Nature Reserve or the gold mining in the Mandor Tourism Park.

A similar situation has arisen in the agro-industrial plantation sector, where the authority of the provincial government is severely limited in terms of both determining activities and exercising control. For example, in order merely to revoke the licence of an entrepreneur or investor who has failed to undertake required investment, a recommendation from an official in the central government must first be obtained. This is because the legal provisions state that an investor receives a plantation license from the central government and not the local government.

\subsubsection{Business and investment}

The utilisation of forests in West Kalimantan, based on Government Regulation No. 21/1970, is carried out by the private sector under the system of Commercial Forestry Concessions (HPH) and Harvest Concession for Forest Product (HPHH). As soon as the regulation was issued, entrepreneurs adopted strategic economic positions in order to exploit the forests. However, by taking this stance, the business community has failed to make any significant contribution to the quality of life of the people of West Kalimantan, or to its economic growth. Similarly, the relationship between the central and regional governments is limited, as reflected in the small distribution of funds from Land and Building Tax (PBB), Forest Product Fees (IHH) and Reforestation Fund (DR). At the time of this study, the respondents from West Kalimantan government strongly felt that the regulations and practices relating to the exploitation of forest areas favoured only big business and the central government.

However, the business community offers a different assessment. Business people holding HPH timber concessions believe that their 
exploitation of the forests has made a real contribution to the overall economic activity in West Kalimantan. For example, people in remote forest areas have benefited from the arrival of the concessionaires through access to the employment market that is created by their activities. The same applies to the programme concessionaires have called 'Rural Development', which they claim has improved the lives of those living in and around the HPH area. Another benefit they put forward is that remote areas have become less isolated as a result of the road network constructed throughout the forests.

In year 2000, to demonstrate its commitment to developing a people-based economy, the Ministry of Forestry and Estate Crops transferred the authority to issue HPH timber concessions for areas up to 10,000 ha to the Governor and for Timber Clearance Permits (IPK) for areas up to 100 ha to the Bupati ${ }^{16}$. Although the Director General of Forest Production subsequently postponed the enactment of this decree, the provincial and district governments had already acted on this authority and decided to continue. This action was partly related to establishing a framework to self-finance regional autonomy and partly based on the demands of local people. As a result, the Bupati of Sintang district continued to issue 100 ha HPHH permits to community groups, even after the Ministry had sought to postpone the transfer of such authority. The governor did not prohibit such actions and, in October 2000, he also issued a decree ${ }^{17}$ regarding $\mathrm{HPH}$ of less than 10,000 ha.

There are some problems related to the issue of these HPHH permits. In West Kalimantan, when local people have obtained the rights to harvest forest products but do not have the capital or equipment to operate the HPHH area, they have teamed up with timber companies holding $\mathrm{HPH}$ concessions under a 'profit-sharing' arrangement. In this way, a few well-established big players will continue to dominate forest utilisation in West Kalimantan even under decentralisation. Despite the provincial government's plans for forest exploitation to contribute to regional development, it is clear that HPH activities and the accompanying wood industries have already exceeded the capacity of the forest areas. An official of the Regional Office of the Ministry of
Industry and Trade explained that the plywood industry is experiencing problems with the procurement of raw materials due to log scarcity in some areas. The industry is being forced to operate below capacity and a number of businesses have already closed.

Similar conditions are reported in the sawmilling industry of West Kalimantan, following a rapid increase in the number of mills established without direct links to a HPH timber concession holder or a logging company holding an IPK (Timber Clearance Permit). In such a climate it is hardly surprising that the national parks of the province are being seen as alternative sources of timber. One member of the provincial legislative assembly (DPRD) even believes that some of these interests regard the national parks as the only logical option left open to them to support a range of operations, including raw materials for the wood industry, despite the fact that this breaks formal laws.

\subsubsection{Local communities and adat customary rights}

Based on the historical origins and local traditions, many local communities or adat (customary law) community groups living in and around the forests claim to be the legal and authentic heirs to the management and utilisation of forest resources. Indeed, before the existence of the HPH concession system, forest products had long been utilised by adat community groups, both for exchange and consumption. Adat leaders in many areas claim that the forests and their communities are inextricably linked, such that it is impossible to separate the people from their source of livelihood whether from an economic, political or cultural standpoint, especially as this relationship also has a sacred religious and cultural value.

In many areas, the issuance of timber concession licences to the private logging companies has had tragic consequences for the people around the forest. Their use of the forests has been severely restricted and, not infrequently, even denied completely. This was particularly true during the 1990 s, with the establishment of Industrial Timber Plantations (Hutan Tanaman Industri, HTI) and large-scale agro-industrial plantations. At that time it became clear that the sources of livelihood for the community groups in and 
around the forests were disappearing rapidly. Moreover, many of these communities have become socially isolated. Community leaders in the Ketapang district explain that their social exclusion is reflected by their declining economic status. Originally the owners of the land, they have become labourers selling their services to the big companies who have come onto their land to exploit the forests.

Where large-scale private plantations surround village dwellings, these communities become enclaves in the sense that the socio-economic needs of the surrounding people are not integrated functionally into the plantation company's operations. Aware of this situation, the central government issued a decree requiring plantations to develop investment schemes that include community cooperatives as shareholders. ${ }^{18}$ However, for the greater part of the regional community, the provisions contained in this decree are not the solution. For plantation investors, it is very difficult to find a cooperative capable of acting as an equal partner. Officials at the Provincial Plantations Office, for example, claimed that they were 'forced' to be innovative and ask investors to draw up a formal, witnessed contract indicating willingness to facilitate the establishment of a cooperative involving local people as their business partners. The cooperative institution formed would be a Members' Primary Credit Cooperative (KKPA) that would enable local people to own a plantation. This would be developed by a plantation company, which would provide the necessary loans to run the project.

\subsubsection{Forestry and plantations}

\subsubsection{Forestry}

The issuance of Government Regulation No. 21/ 1970 marked the beginning of the intensive utilisation of the forests in West Kalimantan by state-owned enterprises, private sector investors and joint venture companies. ${ }^{19}$ The first HPH in West Kalimantan, totaling 538,500 ha, was obtained by PT. Jamaker Kalbar Jaya, a company owned by the Indonesian Armed Forces. ${ }^{20}$ This concession ran the entire length of the border between Indonesia and Malaysia and was officially justified by 'national security considerations'.

By March 1998, 71 HPHs had been issued for West Kalimantan, covering 7,136,000 ha. By March 1999, 17 of those licences were inactive; the remainders were either still active or in the process of renewal as state-owned enterprises, joint

Table 8. HPH Timber Concessions in West Kalimantan, 31 March 1999

\begin{tabular}{lrr}
\hline Item & Number & $\begin{array}{c}\text { Area } \\
\text { (ha) }\end{array}$ \\
\hline HPH Decisions, issued & 71 & $7,136,000$ \\
HPH Decisions, still active: & 33 & $4,035,400$ \\
Continuing & 19 & $1,797,300$ \\
Joint ventures with state-owned enterprises & 4 & 446,000 \\
Renewed & 2 & 832,500 \\
Currently in extension/renewal process & 8 & 959,600 \\
\hline Decrees on HPH awarded to state-owned enterprises: & 21 & $1,980,000$ \\
PT. Inhutani II & 20 & $1,784,000$ \\
PT. Inhutani III & 1 & 196,000 \\
\hline HPH Decrees, not active: & 17 & $1,120,600$ \\
Revoked & 11 & 673,500 \\
Expired and not renewed & 5 & 388,000 \\
Returned to Minister of Forestry and Estate Crops & 1 & 59,100 \\
\hline
\end{tabular}

Source: West Kalimantan Forestry Office (2000). 
ventures or private companies (Table 8). Total size of this area covered $63.17 \%$ of total forest in West Kalimantan, categorized as a cultivation area in the TGHK (Table 1).

The granting of HPH timber concessions to private sector investors has resulted in the rapid growth of wood processing industries, especially with Indonesia's 1985 ban on log exports. The first wood processing company to operate in the province was the plywood producer, PT. Rimba Ramin, established in 1971 with an annual production capacity of $27,000 \mathrm{~m}^{3}$; this company remains active today (Ministry of Industry and Trade 1998). Currently active industries include: 17 plywood mills (with a capacity of $1,500,950 \mathrm{~m}^{3}$ per year); 42 sawmills $\left(631,680 \mathrm{~m}^{3}\right.$ per year); and 60 woodworking businesses $\left(1,270,798 \mathrm{~m}^{3}\right.$ per year). These industries can produce $2,664,537 \mathrm{~m}^{3}$ of processed wood products consisting of: plywood $\left(977,953 \mathrm{~m}^{3}\right)$; sawn timber $\left(131,206 \mathrm{~m}^{3}\right)$; moulding $\left(81,939 \mathrm{~m}^{3}\right)$; dowel $\left(3,902 \mathrm{~m}^{3}\right)$; blockboard $(69,070$ $\left.\mathrm{m}^{3}\right)$; wood working $\left(6,015 \mathrm{~m}^{3}\right)$; particleboard $\left(182,280 \mathrm{~m}^{3}\right)$; fancy plywood $\left(16,239 \mathrm{~m}^{3}\right)$; veneer $\left(1,037,855 \mathrm{~m}^{3}\right)$ and other products $\left(159,074 \mathrm{~m}^{3}\right)$.

This rapid growth in the capacity of the wood processing industry has outstripped the supply of raw materials, which is declining steadily. The log production target for 1999/2000 was $1,252,560 \mathrm{~m}^{3}$, of which $896,965 \mathrm{~m}^{3}$ was from HPH Annual Management Plans, 54,967 $\mathrm{m}^{3}$ was from Forestry Work Programmes ${ }^{21}$, while $327,628 \mathrm{~m}^{3}$ was from Timber Clearance Permits (IPK). The actual wood felled during the year was $704,828 \mathrm{~m}^{3}$ (56.27\% of the target). This meant that production fell far short of the capacity of the wood processing industry. The total capacity of the wood processing industry is $3,403,428 \mathrm{~m}^{3}$ per year (West Kalimantan Regional Forestry and Estate Crops Office 2000). The province's wood processing industry partially filled this deficit by obtaining $1,690,038 \mathrm{~m}^{3}$ of $\operatorname{logs}$ from outside the province $^{22}$ to meet its effective demand of 3.4 million $\mathrm{m}^{3}$. This indicates that more than 0.8 million $\mathrm{m}^{3}$ timber was supplied from illegal sources.

A national shortfall in industrial wood raw supply led the central government to institute the Hutan Tanaman Industri (HTI) development policy in the early 1990s. ${ }^{23}$ In West Kalimantan the development of HTI plantations began in 1991/1992, with the allocation of large forested areas for conversion to tree plantations. By 1999, 887,040 ha of forestland was reserved for HTIs, although the actual area planted was a mere 117,179 ha or $13.21 \%$ (West Kalimantan Kanwil Office 2000). This low figure is partially a result of land conflicts with the local communities. It also reflects the fact that it is common for companies that have been awarded HTI conversion permits to not actually carry out any planting but merely harvest the timber from the forested areas allocated.

\subsubsection{Agro-industrial tree plantations}

The West Kalimantan provinical government has also prioritised the development of agro-industrial tree plantations to maximise the potential of the province's agro-ecosystem. The traditional crop widely grown by the local people, is rubber. A 1991 study by Institut Pertanian Bogor (IPB) in West Kalimantan showed that 5,200,000 ha of land was suitable for agricultural development. Of this, $2,500,000$ ha was for plantations; this is reflected by the allocation in the Provincial Spatial Plan

Table 9. West Kalimantan Agro-industrial Plantations by ownership

\begin{tabular}{|c|c|c|c|c|c|c|}
\hline Ownership & $\begin{array}{r}1997 \\
\text { (ha) }\end{array}$ & $(\%)$ & $\begin{array}{r}1998 \\
\text { (ha) }\end{array}$ & $(\%)$ & $\begin{array}{r}1999 \\
\text { (ha) }\end{array}$ & $(\%)$ \\
\hline Community plantations & 704,474 & 86.23 & 717,405 & 82.56 & 709,965 & 80.02 \\
\hline \multicolumn{7}{|l|}{ State-owned } \\
\hline large-scale plantations & 28,557 & 3.5 & 31,100 & 3.58 & 29,230 & 3.29 \\
\hline Private large-scale plantations & 83,961 & 10.28 & 120,442 & 13.86 & 148,079 & 16.69 \\
\hline TOTAL & 816,992 & 100 & 868,947 & 100 & 887,274 & 100 \\
\hline
\end{tabular}

Source: West Kalimantan Plantations Office (2000). 
(RTRWP). The types of crop recommended by this study were rubber, kelapa dalam ${ }^{24}$, hybrid palm, oil palm, coffee, pepper and cocoa. By early year 2000 , there were 887,274 ha $(27 \%$ of reserved plantation area) (Table 9), while a total of 125 companies had been issued with licences in principle by the West Kalimantan Provincial Plantations Office, covering a land area of 1.17 million ha. It is interesting to note that land allocated for plantations by the governor exceeds $(3,319,328$ ha, the land allocation in the RTRWP) by 819,328 ha (Table 10). The introduction of the People's Plantation Development Project (PPKR) in 1979-1980, funded by the World Bank, was the first plantation project in West Kalimantan. This was carried out under a system of Project Executive Units, whose main job was to revive and expand the area of peoples' rubber plantations by $13,000 \mathrm{ha}$; these activities were restarted in 1985-1986 with a target planting of 30,000 ha. ${ }^{25}$

The second system used was the PIR scheme (Perkebunan Inti Rakyat or People's Core Plantations), which started in Ngabang in 19801981. At that time, oil palm was becoming more familiar to the people as a result of aid from the World Bank's NES V (Nucleus Estate Smallholder) project. Plantations covering 14,500 ha were started, consisting of core plantations of 3,500 ha and plasma plantations of 11,000 ha for 5,500 participating families. With further support from the World Bank's NES VII, a 15,000 ha rubber plantation was developed as a project executive company in Monterado, Sanggau district; it consisted of 3,000 ha of core plantation and 12,000 ha of plasma plantation for 6,000 participating families. The PIR system remains in use both in its original form and in conjunction with the transmigration program. The Transmigration-PIR system was first implemented in 1985-1986 in Kembayan, Sanggau district, by PTP VII with 15,000 ha of land for 6,000 participating families.

The Private Large-Scale Plantation (PBS) system was first used in 1986 with cocoa crops in Toho, Pontianak district. By December 1999, the Governor had issued 159 licences for PBSs in West Kalimantan, with a total area of 2,394,233 ha. Meanwhile, 100 PBS companies had received 'plantation business clearance in principle' documents for 993,983 ha. As of 2000, the status of these mostly oil palm PBSs was as follows: 54 had planted 91,231 ha; 19 were at the survey stage; five were at the pre-survey stage; and 11 were not yet at the pre-survey stage. The operating licences of the other 24 PBSs may be revoked because they are assessed as having neglected 15,000 ha of land. The amount of land allocated for the latter PBSs is actually 268,692 ha (West Kalimantan Provincial Plantations Office 2000). Land allocated to plantation in West Kalimantan (Table 10) was dominated by PBS that covered the total area of $71.91 \%$; the remainder were PIR-Bun (peoples' core plantation), PIR-trans (transmigrants' core plantation), and PIR-KKPA (member's primary

Table 10. Land Allocated to Plantations in West Kalimantan, 2000

\begin{tabular}{lrrrrrrr}
\hline District & $\begin{array}{r}\text { PBS } \\
\text { (ha) }\end{array}$ & $\begin{array}{r}\text { PIR- } \\
\text { BUN } \\
\text { (ha) }\end{array}$ & $\begin{array}{r}\text { PIR- } \\
\text { Trans } \\
\text { (ha) }\end{array}$ & $\begin{array}{r}\text { PIR- } \\
\text { KKPA } \\
\text { (ha) }\end{array}$ & $\begin{array}{r}\text { PTP } \\
\text { (ha) }\end{array}$ & Total & Actual \\
& & & & & & \\
Pontianak & 534,839 & 41,700 & 33,500 & 12,000 & 0 & 622,039 & 210,547 \\
Sambas & 294,892 & 64,500 & 37,830 & 0 & 0 & 397,222 & 167,340 \\
Sanggau & 408,400 & 30,000 & 207,850 & 85,550 & 24,000 & 755,800 & 236,540 \\
Sintang & 424,862 & 31,500 & 22,800 & 28,500 & 0 & 507,662 & 110,161 \\
Kapuas Hulu & 299,250 & 0 & 0 & 0 & 0 & 299,250 & 30,621 \\
Ketapang & 431,980 & 0 & 144,225 & 171,150 & 0 & 747,355 & 131,165 \\
\hline TOTAL & $2,394,223$ & 167,700 & 446,205 & 297,200 & 24,000 & $3,329,328$ & 886,374
\end{tabular}

Source: West Kalimantan Plantations Office (2000)

Notes: $\quad$ PBS = private large-scale plantations; PIR-Trans = transmigrants' core plantations; $\quad$ PTP = state-owned enterpris
PIR-KKPA = members' primary credit cooperative-people's core plantations;

PIR-BUN = people's core plantations; 
credit cooperative-people's core plantation) of total area $27.37 \%$ and PTP (State-owned enterprises) $(0.72 \%)$. The fact that PIR (People's Nucleus Plantation) had smaller area than PBS indicated the low level of local communities' participation in the development process of modern plantation and in formal forest management in West Kalimantan.

Much plantation ownership in West Kalimantan is still in the hands of local communities (Table 9). However the declining percentage highlights the priority given to big businesses, whether stateowned enterprises, Indonesian private sector companies or foreign investors. Many informants indicated that they anticipate conflicts will arise if local people find it increasingly difficult to gain access to plantation development because land is only being allocated to big businesses.

Rubber remains the most important plantation crop, both on community and private plantations, with 887,274 ha used for rubber plantation. This is followed by kelapa dalam with 93,224 ha, hybrid palm with 11,889 ha, oil palm with 290,732 ha, cocoa with 8,629 ha, pepper with 4,377 ha, coffee with 9,930 ha, and other crops with 7,364 ha.

Many entrepreneurs and provincial and government officials interviewed for this study asserted that investment in the plantation sector is hampered by legal provisions that oblige investors to use the cooperative system..$^{26}$ This system is perceived as being Java-biased, because the capacity of human resources in West Kalimantan is inadequate for this cooperative system to be effective, and because of the province's low population density. Additional factors that have constrained investment include a lack of capital, high interest rates, limited amounts of palm oil seed, and overlapping regions and land allocations. Moreover, the administrative processes that entrepreneurs have to follow to rehabilitate exforest areas are long and complicated. This has become a frequent excuse for many investors simply to leave these areas once the timber is harvested. Many informants also reported that it is not unusual for entrepreneurs to apply for a plantation development permit when they are really only interested in the IPK permit, which they can then use to freely exploit the wood. They have no plans to rehabilitate the land once they have extracted the timber.

\subsubsection{The economic role of the forestry and plantation sector}

The forestry subsector remains one of the most dependable contributors to the West Kalimantan Gross Regional Domestic Product (GRDP), even though it is relatively small in absolute terms. In 1999, forest utilisation in West Kalimantan resulted in total Provisi Sumber Daya Hutan, or Forest Resource Rent Provision (PSDH) of Rp 47 billion and reforestation funds of nearly Rp 60 billion and US\$1.6 million. Based on the prevailing legislation, West Kalimantan received only $30 \%$ of total PSDH-almost Rp 14 billion (non-tax profit distributions) - whilst it was reported that all the reforestation funds went to the central government.

Meanwhile, plantation activities were increasing, with a total production of all crop types in 2000 of 573,000 tons. Of this, 129,000 tons with a value of US\$69 million were exported. The total contribution of plantations to the 1999 GRDP was Rp 497 billion (at 1993 prices), with a growth rate of $9.49 \%$.

Clearly the forestry and plantation sector remains a major contributor to the regional economy. In addition, these two subsectors play a strong role in supporting the growth of other sectors, such as industry and trade, and also attract new investors to the province. Investment activities have a positive impact on the GRDP. Domestic investment in West Kalimantan up to December 1999 amounted to $\mathrm{Rp} 3$ trillion, with 266 companies and 204 projects employing 76,018 people. The largest investment was in the plantation subsector where 68 companies invested nearly $\mathrm{Rp} 2$ trillion, followed by the forestry subsector and the wood industry. Meanwhile, foreign direct investment reached US $\$ 125$ million in 62 projects employing a total of 8,729 people.

\subsection{DECENTRALISATION OF THE FORESTRY AND PLANTATIONS SECTOR}

\subsubsection{Conflicts between stakeholders}

The extremely high potential of West Kalimantan's forest resources has resulted in a three-way tugof-war among the adat community groups, the government and the business community, at both regional and national levels. The most striking 
illustration is given by attempts by some interests to convert land designated as part of the Forest Estate under the Forest Land Use Consensus (TGHK) Spatial Plan so that it can be used for non-forestry activities. The multitude of problems and challenges means that many forestry issues can no longer be dealt with at the sectoral level. Forestry problems in West Kalimantan have escalated into a complex dilemma to be faced at local, district/provincial and national levels. In areas like the prevention of forest fires and conservation of national parks, they have also become matters of concern to the international community. The conflicts among stakeholders partly were caused by weakness of formal accessibility of local communities and local authority to forest resources. These conflicts were one of the indicators of de-facto decentralisation (informal) or indeed indicated that there was a need for decentralisation in this area.

\subsubsection{Forest area land use and management}

The provincial government has been and will continue to be forced to carry out non-forestry sector activities on land classified as 'forest', particularly on the TGHK map. Law No. 24/1992 gives regional governments the authority to re-classify the land uses in their regions through the Provincial Spatial Plan (RTRWP). However, the compilation of this plan must somehow take into account the different interests of the provincial and district governments and the forestry sector. It is often a long and complicated process to officially change the land's function from its original status as part of the Forest Estate area (Kawasan Hutan), even though the actual utilisation of this land has frequently already changed on the ground. This creates problems for the provincial and district governments because of the strict limitations on the kind of activity allowed on land within the Kawasan Hutan. For this reason, provincial and district governments and related offices and agencies believe a new agreement is necessary by creating a provincial-scale 'harmonised' map which will be the basis for all land use matters. At the time this field research was completed, the process of creating the 'harmonised' map, combining TGHK and the RTRWP, had yet to be completed.

A provincial Bappeda official commented that the
Governor has, on several occasions during the last few years, acted on his own initiative and overridden all existing legal regulations, for example, by allocating more land for plantation investment than was available for that purpose. This kind of action has been prompted by the provincial government's need for a rapid increase in regionally-generated revenues (PAD).

It is interesting to note that the province is not involving the district governments or any suboffices in the preparation of the new 'harmonised' map. In the context of decentralisation and regional autonomy, this promotes suspicions that there is a provincial-level interest (as well as a central government one) in retaining authority over forest administration. This notion is supported by the fact that the transfer of authority over forest administration to the district governments is not explicitly mentioned in Government Regulation No. 25/2000, creating the opportunity for drawnout disagreements about decentralising authority in forestry matters.

Officials at the national government's Regional Forestry and Estate Crops Offices (or Kanwil) and at the provincial government's Dinas Kehutanan, generally believe that the time is not right for forestry matters to be fully transferred to the district-level government because of human resource limitations. For this reason, these two offices recommend that decentralisation would be more effectively carried out in stages, based on the district government's capacity. Officials in the Provincial Forestry Offices tend to reject the idea of forming an autonomous forestry office at the district level, proposing only Technical Executive Units at the subdistrict (Kecamatan) level. Under this arrangement, the district government would still have no authority over forest management.

\subsubsection{Protected areas}

The weakness of the provincial government in the decentralisation process is also displayed in the case of the protected forest area in Bukit Baka in the Sintang district. The provincial government could do nothing when the Kanwil included a part of this area as a HPH timber concession. Provincial authorities tried to uphold the area's status as protected forest by referring to the existing legal provisions. However, the central government 
ultimately came down in favour of the HPH concessionaire, although there was an accompanying agreement that this overlap area would be returned to its status of protected forest after two years. This is just one example among many of the weak position of the provincial government when dealing with the central government.

\subsubsection{The timber industry}

A careful assessment of the soaring number of sawmill businesses shows there are conflicts between sectoral interests, i.e., between the Forestry offices and Industry Offices at provincial level. The Forestry Offices tend to limit the number of large-scale wood businesses with HPH timber concessions and IPK wood utilization permits so that the forest management process will theoretically be more accountable. The Industry Offices tend not to take HPH/IPK decisions into account when granting a commercial licence for a wood business. Their sectoral interest is to expand industrial development as much as possible. The scarcity of raw materials resulting from a sharp increase in the number of these wood processing industries is one factor behind 'illegal logging', both by HPH concessionaires (within and outside the HPH areas) and by non-HPH entrepreneurs who organise the local people as loggers.

\subsubsection{Illegal logging}

Concern has been mounting in a number of quarters about the rapid increase in illegal logging in West Kalimantan, much of which is carried out by the local people, many of whom are organised and backed by the private sector. The provincial government believes that without local policies capable of dealing with the situation, these illegal logging practices pose a serious threat to forest preservation. It sees illegal logging as a result of two main factors: 1) the push factor created by an imbalance in access to production forest between non-local HPH concessionaires and the local people; and 2) a pull factor of high demand for products from wood industries, both within the province and outside, particularly Java and Malaysia (Sarawak). At the same time, neither the provincial or district governments have the capacity to control illegal logging without the authority to regulate forest management (e.g., issuance of HPHs) and the wood trade (e.g., transportation licences). The central government formally holds this authority, but legislation is such that the regional forestry officials- who make the decisions- appear to be able to freely obtain special treatment as individuals. Consequently, they are likely to favour continuation of the old system of control.

It should be noted that while West Kalimantan has the capacity to produce 2.4 million $\mathrm{m}^{3}$ of wood, a member of the provincial legislature believes about half this capacity is supplied through 'illegal logging'. It is also believed that Malaysia is supplying the international market with unprocessed timber from Indonesia, particularly from West Kalimantan. This is despite a formal ban on Indonesian log exports.

Generally, officials of the provincial government interviewed for this study seemed to be largely 'unconcerned' by illegal logging. They propose that the practice actually constitutes a form of local resistance to forestry policies that are unfriendly to the local economy of the area. Illegal logging does not directly contribute to regional revenues (PAD), but indirectly, the multiplier effects generate growth in other sectors like transportation by (land/inland waterway/sea), hotels, wholesale trade, and small scale wood industries, as well as informal employment and business activities. Since these sectors contribute to the local economy through contributions to GRDP and the employment of local people. The local government tends to overlook illegal logging. Moreover, the costs of eradicating illegal logging cannot be compared to the economic benefits directly received by the local government.

\subsubsection{State-owned enterprises}

Responsibility for the rehabilitation of former HPH forest areas has been delegated to PT. Inhutani II, a state-owned enterprise (Badan Usaha Milik Negara or BUMN). However, a number of subdistrict heads in the Ketapang area assert that Inhutani is actually continuing to exploit the remaining forest in these areas, leading to calls for its operating permit to be revoked. Several officials interviewed for this study argued that the central government (through its BUMNs) is actually participating in illegal logging on a major scale.

Members of the Provincial Legislative Assembly 
(DPRD) have also highlighted the process whereby PT. Inhutani II was assigned the rights to rehabilitate former $\mathrm{HPH}$ areas and then subcontracted its management rights to other parties. These other parties were apparently only interested in making a profit. They acted like new HPH concessionaires, extracting all of the remaining wood from areas allocated to them. One HPH concessionaire explained that PT. Inhutani II had neither the financial nor physical capacity to rehabilitate these areas; it had a file full of licences and permits that it was sold to subcontractors. Provincial and district officials interviewed for this study claimed that Inhutani II can be regarded as having failed to meet its commitment to reforestation; and that it was really only seeking financial profits.

\subsubsection{Incentives and disincentives}

When $60 \%$ of the Kapuas Hulu district was declared a conservation area, a general ban was placed on extracting timber and processing wood products within it. The head of the West Kalimantan KSDA (Natural Resources Conservation) Unit describes the reaction of local government officials and people as one of perceived injustice - they saw that other districts were gaining greater benefits from their forests. By declaring the district a conservation area, the potential of the forest areas to contribute to PAD was seriously diminished. This situation must be resolved before a satisfactory response can be made to demands such as that by the head of the Kapuas Hulu district for the amount of protected land to be reduced so that its forest resources can be exploited. This will necessitate cross-district cooperation in creating an incentive system that suits the Kapuas Hulu district, which in this case acts as the 'steward' for preserving the flow of the Kapuas River.

\subsubsection{Indicators of decentralisation}

The reversal of the central-regional imbalance in control over forest management is already becoming apparent. An important milestone was when governors and heads of districts were given the right to issue HPHH (Hak Pemungutan Hasil Hutan or Forest Product Harvest Concessions), which permit people to extract timber on a smallscale. In addition, adat/local community groups are being recognised as the main stakeholders in forestry affairs. This is directly attributed to the efforts of non-governmental organisations (NGOs) in West Kalimantan, who have fought hard for the rights and empowerment of adat communities in natural resource management. These efforts have been ongoing for some time, beginning even before regional autonomy and Laws 22 and 25 of 1999 . This increased power is reflected, for example, by local officials having the opportunity to participate in drawing up regional maps of the local area and its resources - an initiative by a local NGO. The resulting map can be seen as a symbol of the normative authority of the communities over the regulation and utilisation of their own natural resources. The people in the hamlet of Sahamp, Pontianak district, already have their own participatory map of the area, and they made a collective decision not to allow oil palm planting in their area.

Decentralisation will also bring significant administrative changes in the institutional and organisational sectors. The power of the Kanwil, as representatives of the central government, was gradually reduced, leading to the ultimate closure of these agencies in December 2000.

In the plantation sector, decentralisation has resulted only in a backlash against the provisions in Decree No. 107/1999 dealing with systems suitable for plantation development. The decree stipulates that the local community must be involved in large-scale plantation businesses through investment in partner cooperatives specifically set up for such a purpose. In reality, these conditions are hard-to-implement in the interior of West Kalimantan because the geographic distance between inhabited areas inhibits implementation. There are other structural problems too, such as the relatively low level of skilled human resources available. One solution to this problem, according to provincial-level Dinas Perkebunan officials, is to require potential entrepreneurs to draw up a legal agreement that they will, at some time in the future, set up a partner cooperative as intended under central government policies. By merely producing this document, an entrepreneur will be judged to have met the requirements of the decree, even though there is no guarantee that the partner cooperative will ever be formed. 


\subsubsection{The provincial government's response to the decentralisation process}

At the time this report was written, the process for implementing regional autonomy was not clear, because there had only been one regional regulation detailing the functions and duties of the provincial government. By the end of 2000, the provincial government had made an inventory of the areas in which it held authority, and had consulted with the district governments over their responsibilities. In the struggle between conflicting interests, there are clearly opportunities for officials at the provincial level to assume (and abuse) responsibilities that they believe the district cannot handle effectively. In other words, powers that should be held by the district government will remain in the hands of, or will be taken over by, the province. These matters particularly concern financial issues.

The most significant question of concern to provincial government officials is whether and how the province uses its sources of local revenues (PAD) to stock the regional treasury. However, officials in centrally administered provincial offices had few of the same concerns, despite years of experience in West Kalimantan.

The discrepancies between areas set aside for plantations by the centrally defined TGHK and data issued by the provincial governor's office have been an incentive for the provincial and district governments' Spatial Plans to strongly promote regional growth, and hence maximise its PAD. The governor's data specifies 3.3 million ha as reserved for plantations compared to 2.5 million ha in the Provincial Spatial Plan. Decentralisation (and hence access to a greater area) will allow the province to attract greater numbers of plantation investors, especially in oil palm. Some community groups explain that subdistrict heads actually want to attract investors who are interested in developing and/or rejuvenating community-based rubber plantations through partnerships. In part, this is because district governments do not have the funds to invest in projects to rejuvenate local people's rubber plantations.

In order to resolve this division of authority, provincial officials took the stance that forest and plantation management should be devolved to the regions as a complete package. Under such a plan, decentralisation would not only mean the delegation of authority over forest management but also an accompanying, appropriate share of the finances (especially reforestation funds) as compensation for the loss of forest resources. Thus, the provincial government would be given 'ownership to forest rights'. Provincial officials argued that this would ensure that decentralisation of administrative authority from the central government to the regions was not merely a repackaging of the old practices, which were viewed by informants as exploiting forest resources for maximum profit. Instead, they felt that, if properly carried out, decentralisation would focus more on rehabilitating damage to existing forest areas. They maintain that, if the central government does not accept this goal for decentralisation, district governments will try to maximise exploitation of the forestry, plantation and wood industry subsectors as dependable sources of local revenues. This would result, they further conclude, in forest degradation.

With the central government's transfer of the right to grant licences for Community Forestry Concessions (Hak Pengusahaan Hutan Kemasyarakatan, or HPHKM) to the provincial and district governments, there is concern that community groups, which are given these rights, will be unable to finance their operations, and will therefore be forced into inequitable partnerships with large-scale HPH entrepreneurs. They would then make an agreement, as a cooperative, to 'give' their HPHKM to a large-scale concessionaire, even though the latter is legally obliged to share its gains from its wood products with the cooperative. Thus, if decentralisation policies are not accompanied by close scrutiny of activities on the ground, they may prove to be redundant, despite the fact that more members of local community groups are able to legally enjoy the spoils from forest resources. 


\subsection{FORESTRY AND PLANTATIONS}

\subsubsection{Stakeholders and their roles}

There are three groups of stakeholders in forestry and plantation activities in the Ketapang district: government agencies, industry enterprises (private or state-owned) and local communities. Each of these groups has its own role in the context of forestry and plantation activities, reflecting their different interests. These may either co-exist in harmony, or come into conflict with one another.

\subsubsection{Government agencies}

There are two categories of government agencies with interests in the forestry and plantation sector in the Ketapang district. The first covers the technical (sectoral) agencies that directly administer forestry and plantation activities; while the second includes those agencies that are not directly involved in, but benefit from, or provide limited services to plantation and forestry activities.

Throughout 2000, all the technical (sectoral) agencies directly involved in forestry and plantation activities were under the authority of the provincial or central governments. At the time research was conducted for this study, there was no autonomous forestry and plantation agency in the Ketapang District that was authorised to make decisions in accordance with the district government's policies. The Technical Executive Units (UPT) that directly implement policies are described below:

1. Forest Management District (KPH) Office: an agency of the provincial Dinas Kehutanan that is located in the district to assist with supervision, protection and development of forestry activities.
The Ketapang forest area is divided into two KPH operational areas: Ketapang KPH, south of the Pawan River (nine subdistricts), and Batu ampar $\mathrm{KPH}$, in the Pontianak district, north of the river (five subdistricts).

2. Plantations Branch Office: operates under the Provincial Plantations Office to assist in the supervision and development of plantation activities in the Ketapang District. As with the KPH Office, it acts merely as a support agency and is unable to make administrative decisions related to plantation activities.

3. Gunung Palung National Park (Taman Nasional Gunung Palung, TNGP Authority: a special UPT responsible to the Director General of Nature Protection and Conservation (PKA). The TNGP Authority is located in the city of Ketapang (not within the national park boundaries).

\section{Sub-Management Unit for Forest Inventory} and Mapping (Sub-Biphut): an agency under the direction of the Pontianak Biphut that inventories and maps forest in the Ketapang district.

\section{Natural Resource Conservation (KSDA)} Subsection: duties cover the conservation of natural resources in the protected areas of the Ketapang district. It is responsible to the provincial KSDA unit.

In theory, the head of the district has coordinating authority over all agencies in a region. However, these executive offices feel more responsible to the policy guidelines issued by their supervising bodies. This is because almost all operating costs are paid by these bodies (central budget and level 
I regional budget). The level II (district) regional budget allocates no expenditure to the UPTs, leaving the district head in a weak bargaining position when dealing with these agencies. As a result, the formal role of the Ketapang district government in matters of administration, policymaking and forestry and plantation management has become peripheral. At the time this study was conducted, it was difficult to predict whether the costs of financing the sector would be the responsibility of the regional areas (province/ district) or would remain with the central government. No clarification of policy was available at the time this report was written.

This peripheral standing is also clearly reflected by the limited authority of those technical and nontechnical agencies in the local government that are indirectly involved in the sector by using and providing services to forestry and plantation activities. These bodies include:

1. National Land Agency (Badan Pertanahan Nasional, BPN): issues companies with location permits for Commercial Forestry Concessions $(\mathrm{HPH})$, Timber Plantations (HTI) and plantations based on the instructions from the head of the district. District heads have been authorised to issue these licences since the October 1993 Policy Packet (Pakto 1993) was first implemented; prior to this, the Governor was the issuing authority.

2. District Revenues Office (Dispenda): the regionally autonomous office for identifying district revenues (PAD) through district taxes and levies. In the case of forestry activities, Law No. 18/1997 determined PAD sources to include business taxes, business levies and wood-piling services.

\section{Regional Development Planning Board} (Bappeda): responsible for compiling the District Spatial Plan (RTRWK).

\section{Regional Industry and Trade Office (Dinas Perindustrian dan Perdagangan)}

\subsubsection{Private and state-owned companies}

There are a number of private and state-owned companies in the Ketapang district that are involved in the forestry and plantations sector. The activities of these companies are closely related.
1. HPH concession holders are private companies given rights by the national government to $\log$ within an assigned timber concession. From the perspective of district officials and local community figures, these HPH companies control the greatest part of the Ketapang forest area.

2. PT Inhutani II was specifically set up to undertake rehabilitation programs for ex-HPH forest areas, that is, areas relinquished by or taken away from HPH-holders by the Ministry of Forestry. In addition to reforestation activities Inhutani II also carries out timber extraction through joint ventures and subcontracts. It is directly under the authority of the Kanwil Regional Forestry and Estate Crops Office.

3. HTI companies are private companies that operate industrial timber plantations. There are three HTI systems in the Ketapang district: the Patungan (joint venture) HTI, the Transmigration HTI, and the Murni (sole operator) HTI. ${ }^{27}$

4. Plantation companies: there are now 12 plantation companies operating in the Ketapang district, all producing oil palm. Five are People's Core Plantations (PIR); seven are Private National Large-Scale Plantations (PBSN) consisting of four pure PBSNs and three Members' Primary Credit Cooperative (KKPA) PBSNs.

5. Wood processing industries include the plywood, sawmilling, moulding, and planing industries. The majority of these industries in the Ketapang district are sawmills. There are 52 wood processing industries registered with the Ketapang $\mathrm{KPH}$ Office, many of which are located in the southern part of the district.

6. Illegal wood entrepreneurs (known as cukong) finance and organise both legal and illegal logging activities in the forests. The cukong are involved in wood processing industries and/or wood trading, including exports.

7. Sea transporters are the backbone of the transportation of products from illegal logging, particularly to Java. At the same time, they provide the transport system for trade in the nine basic commodities (sembako). The transporters will only bring sembako into Ketapang district if their ships 
can return to Java with a cargo of wood. One of the leading sea transporters in the district explained that almost all wood brought into Java is from illegal logging.

\subsubsection{Local communities}

Most adat (customary law) or rural communities in the Ketapang district carry out traditional forestry and/or plantation activities. Part of the forest area claimed as adat forest (collective title) is used for swidden agriculture, while another part is reserved for construction materials, forest honey cultivation activities, tengkawang (Shorea spp.) cultivation and hunting. A third part has been converted into a community rubber plantation (See section 4.1 for a discussion of the Dayak communities).

Historically, the people of Ketapang district did not manage the forest areas for large-scale timber extraction, as under the HPH system. It was only after this system came into operation (in about 1975 ) that an adat community group decided to claim collective ownership of certain forest areas, so that this could then be 'sold' to illegal loggers. Efforts to prevent this type of forest exploitation were undertaken by Harvard University's Laboratory of Tropical Forest Ecology (LTFE), in cooperation with local NGOs. This pioneering project in community forestry was aimed at producing wood in the Gunung Palung National Park buffer zone using an ex-HPH area of 8,000 ha. Some local people were organised into a number of community self-help groups (KSM). In mid-2000, this project was temporarily halted following clashes between members of the KSM forum and non-KSM local residents employed in illegal logging in the TNGP area.

In the Ketapang district, local NGOs and other civil society groups have made little progress as most of these were established only in the late 1990s. However, the Dayak Adat Council (DAD), which was established about two decades ago, has made significant progress. The DAD was formed on the initiative of the district government and community leaders, and consists of a district DAD and several subdistrict DADs (notably in areas where the Dayak groups are in the majority). Its goal is to empower indigenous Dayak peoples, in their struggle for the community's adat titles to land and forest resources, and to deal with horizontal and vertical social conflicts, including those in the forestry and plantation sector. The DAD also works to secure the political rights of the Dayak community at the local level.

\subsubsection{Forestry and plantations}

\subsubsection{Forestry}

In the Ketapang district, HPH concession-based forestry only started in 1975. In 1990, there were $24 \mathrm{HPH}$ timber concessions operating in the district. The 1999 data shows only six HPH companies remaining in the Ketapang KPH area, with a total area of 813,000 ha (Table 11).

Of the six HPH concessions remaining in 1999 , only four HPH units are still active and these produced $238,547 \mathrm{~m}^{3}$ of logs in 1998-1999

Table 11. Status of HPH Companies in Ketapang KPH, 1999

\begin{tabular}{|c|c|c|c|}
\hline Name & Status & $\begin{array}{r}\text { Area } \\
\text { (ha) }\end{array}$ & Location (Subdistrict) \\
\hline Suka Jaya Makmur & Active & 207,000 & Nanga Tayap; Sandai \\
\hline Harjhon Timber & Active & 161,000 & Tumbang Titi; Manis Mata \\
\hline Marsela Wana S & Non-active & 59,100 & Nanga Tayap \\
\hline Sumber Jaya Baru Utama & Non-active & 84,000 & Matan Hilir Utara \\
\hline Duaja Corp II & Active & 125,000 & Sei Laur; Sandai \\
\hline Kawedar MT & Active & 90,000 & Sandai \\
\hline Total & & 813,000 & \\
\hline
\end{tabular}

Source: Ketapang KPH Office (1999). 
Table 12. Condition of Timber Industries in the Ketapang KPH Area, 1999/2000

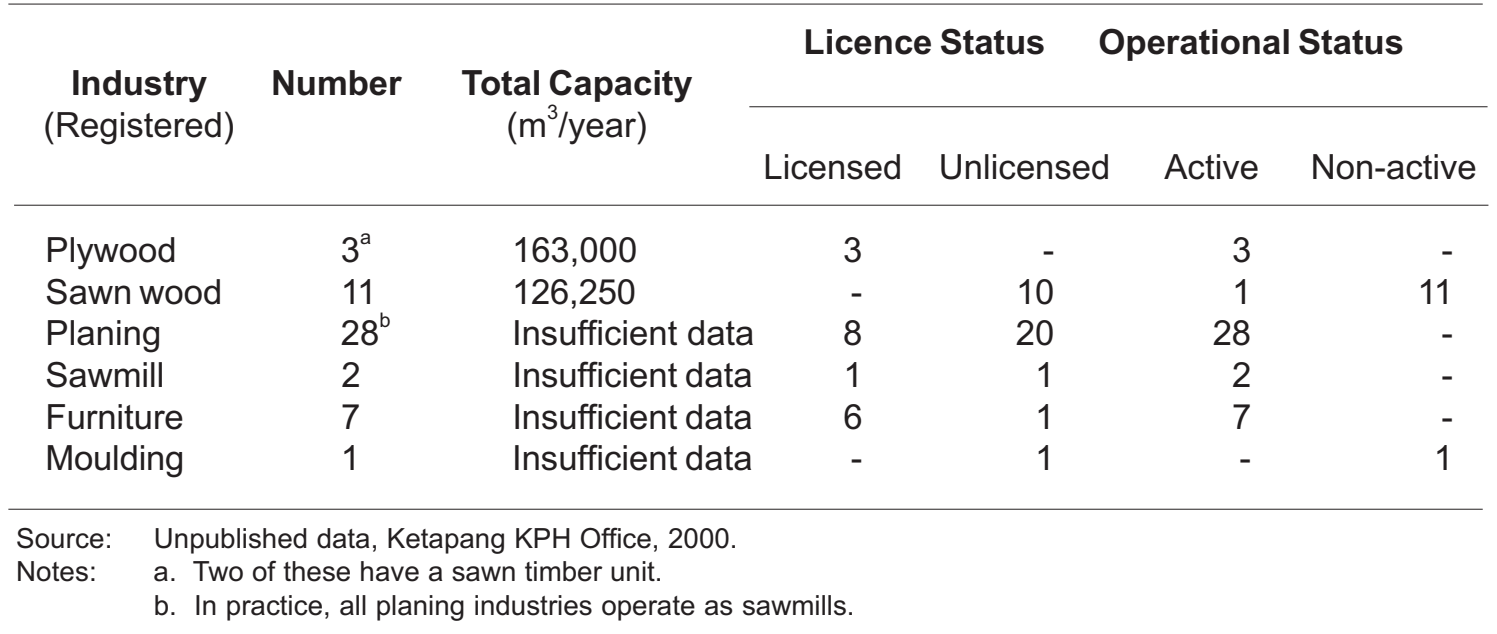

(Ketapang KPH Office 1999). This production level was insufficient to meet the demand for at least $289,250 \mathrm{~m}^{3}$ of raw materials for the 52 plywood and sawmill companies registered at the Ketapang KPH in 1999 (Table 12). Companies therefore had to bring wood in from outside the district; about $80,000 \mathrm{~m}^{3}$ of wood was brought in with the biggest supplier being the province of Central Kalimantan (Ketapang KPH Office 1999). These figures do not reflect the true supply and demand for wood because KPH monitoring reveals that there is a large amount of 'unregistered' wood production and also a large number of 'illegal' companies. $^{28}$

There were three HTI companies in Ketapang in 1999: PT Basuki Rahmat (pulp HTI), PT Lingga Tedja (transmigration HTI) and PT Tawang Maju (murni HTI). In practice, only the murni HTI of PT. Tawang Maju was active, actually planting 350 ha. This extremely slow development - which has also occurred at the provincial level-indicates a lack of commitment to reforestation by both the district government and the investors who have obtained IPK wood utilization permits, which allowed them to clear all remaining timber from an area.

Another activity within the forest is the management of protected/conservation areas. One of the most important protected areas in the district is the Gunung Palung National Park, which is managed by a special UPT outside the structure of the Forestry Branch Office (the national park is discussed in Section 4.3).

\subsubsection{Plantations}

At the time this research was conducted, the total land area in Ketapang that had been designated for plantation development was 961,805 ha. This includes plantation land of 330,474 ha as well as 631,331 ha of dry fields. In April 2000, 123,523 ha of the potential plantation land was already being used: 89,715 ha for oil palm, 22,157 ha for rubber, 9,703 ha for coconut, and 1,948 ha for coffee. (A more detailed discussion of these plantations is presented in Section 4.2).

There are currently four plantation systems operating in the Ketapang district, particularly related to rubber and oil palm plantations, which are outlined below:

1. Swadaya (self-sufficiency) system: this is aimed at developing people's plantations through community-based management, and is commonly used for rubber.

\section{Private National Large-Scale Plantation} (PBSN) system: within this system companies can either work alone to develop oil palm plantations (murni), or in partnership with the local community via Members Primary Credit Cooperatives (KKPA), thus providing investment opportunities for members of the community. This system is most commonly used to develop oil palm plantations. 
3. People's Core Plantation (PIR) system : this is a cooperative system where private and national large-scale companies develop and manage the core plantation, while the people in the surrounding area are able to develop plasma plantations. Again, this system is most commonly used to develop oil palm plantations.

\section{Development Service Unit (UPP) system (for rubber plantation)}

Between 1993 and 2000, forty-three investors had been allocated land to develop oil palm plantations, with a total area of 741,809 ha. By 2000 , only twelve of these companies had actually been established, consisting of five Transmigration-PIR companies and seven PBSN companies (four of these had formed partnerships with community Members Primary Credit Cooperatives (KKPA) and there were three murni, or sole operator PBSN. Five of these twelve plantation companies (operating in Tembelina, Singkep, Sungai Laur and Manis Mata) already had CPO processing plants with a capacity of 1,000 tonnes/month per plant. The area of oil palm plantations developed by these 12 companies by 1999 was only 89,433 ha $(51,112$ ha of PIR and 38,321 ha of PBSN).

The Transmigration-PIR and the KKPA-PBSN systems are structured differently in relation to the division of management responsibilities between local people and the company involved in the scheme. In September 1999, under the Transmigration-PIR system, the majority of land was either managed or designated for management by local farmers to develop plasma plantations $(33,912 \mathrm{ha})$. The total core plantation area managed by the company was about half of this area $(17,200$ ha). The actual area of land converted to outright farmer-ownership under the Transmigration-PIR system remains small, about $10.2 \%$ (3,453 ha) of the total plasma area developed Under the KKPAPBSN system, most of the plantation land is managed by the company (target of 43,300 ha for the companies), while the area controlled or designated for management by farmers is very small ( $8,000 \mathrm{ha})$; of this only 1,696 ha $(24.2 \%)$ has actually been realised (Tables 13 and 14).

\subsubsection{Contributions to the regional economy}

Forestry and plantation activities made a significant contribution to the Ketapang district's regional economy. Between 1994 and 1998, the four main contributions to the Ketapang Gross Regional Domestic Product (GRDP) came from the agriculture, industry and trade and transportation sectors; the forestry and agro-industrial plantation operations did generate a significant share of the contributions provided by each of these subsectors (for example, via employment generation). However, forestry and agro-industrial plantation operations played a smaller role in providing direct contributions to the GRDP. Revenues from this sector are categorised as profit sharing (between the central and provincial governments); as tax sources (particularly Pajak Pertambahan dan

Table 13. Transmigration-PIR Oil Palm Plantations in the Ketapang District, September 1999

\begin{tabular}{lccc}
\hline Name of Company & $\begin{array}{c}\text { Core Plantation } \\
\text { (ha) }\end{array}$ & $\begin{array}{c}\text { Plasma Plantation } \\
\text { (ha) }\end{array}$ & $\begin{array}{c}\text { Conversion } \\
\text { (ha) }\end{array}$ \\
\hline PT. Subur Ladang Andalan & 4,000 & $5,182^{\mathrm{a}}$ & 905 \\
Bangun Maya Indah & 4,000 & 5,827 & 883 \\
PT. Duta Sumber Nabati & 3,000 & $8,915^{\mathrm{b}}$ & 398 \\
PT. Antar Mustika Segara & 2,200 & 8,800 & 813 \\
PT. Poliplant Sejahtera & 4,000 & $5,188^{\mathrm{c}}$ & 454 \\
\hline Total & $\mathbf{1 7 , 2 0 0}$ & $\mathbf{3 3 , 9 1 2}$ & $\mathbf{3 , 4 5 3}$ \\
\hline
\end{tabular}

Source: Unpublished Ekspos data, Plantations Branch Office, Ketapang, 2000.

Notes: a. Based on company reports, 6001 ha, but 819 ha of this land is extremely poor quality.

b. Based on company reports, 11800 ha

c. Based on company reports, 9,763 ha, of which 3,333 ha of this land was damaged by fire in 1997 and 1,242 ha of the land is extremely poor quality. 
Table 14. Private Plantations in the Ketapang District, September 1999

\begin{tabular}{lcccc}
\hline Company & \multicolumn{2}{c}{$\begin{array}{c}\text { Company } \\
\text { Target }\end{array}$} & $\begin{array}{c}\text { Plantation (ha) } \\
\text { Realised }\end{array}$ & \multicolumn{2}{c}{$\begin{array}{r}\text { KKPA Plantation (ha) } \\
\text { Target }\end{array}$} & $\begin{array}{r}\text { Realised } \\
\hline \text { PT. Harapan Sawit Lestari }\end{array}$ & 8,000 & 3,923 & 2,000 & 1,000 \\
PT. Ayu Sawit Lestari & 8,000 & 6,066 & 3,000 & 0 \\
PT. Harapan Hybrida Kalbar & 10,600 & 4,100 & 2,000 & 0 \\
PT. Prakarsa Tani Sejati & 16,700 & 9,981 & 1,000 & 696 \\
PT. Swadaya Mukti Prakarsa & 12,000 & 808 & (non-KKPA) & \\
PT. Budi Naya Agro Lestari & 10,000 & 1,643 & (non-KKPA) & \\
PT. Sandika Nata Palma & 17,000 & 3,800 & (non-KKPA) & \\
\hline Total & $\mathbf{8 2 , 3 0 0}$ & 30,321 & $\mathbf{8 0 0 0}$ & 1696 \\
\hline
\end{tabular}

Source: Unpublished Ekspos data, Plantations Branch Office, Ketapang, 2000.

Bangunan, Land and Building tax or PBB); and as non-tax revenues (particularly Iuran Hasil Hutan, Forest Products Payment or IHH). In the 1999/2000 budget year, the Ketapang district government received Rp 1.13 billion and Rp 379.3 million respectively from the forestry and agro-industrial plantation subsectors. In the forestry subsector this amounted to only $18.6 \%$ of the total PBB profit sharing revenues. This amount was far less than the income received from mining sector, which was 3.41 Billion (55.9\%). Receipts from IHH profit sharing, one of the non-taxable items, were also low: only Rp 2 billion in 1999/2000 (Table 15). The implementation of Law No. 25/1999, which specified the fiscal balance between central and regional governments, meant that the provincial government could expect to set targets for revenues for this subsector, and to obtain a higher share of the revenues generated by this subsector.

Up to the time this study was conducted, direct contributions to regionally generated revenues

Table 15. Ketapang District Revenues from Tax and Non-Tax Profit Sharing, 1999/2000

\begin{tabular}{lrr}
\hline No. Revenues Item & $\begin{array}{r}\text { Target } \\
\text { (Rp 000 000) }\end{array}$ & $\begin{array}{r}\text { Realised } \\
\text { (Rp 000 000) }\end{array}$ \\
\hline I. Tax Profit Sharing & $\mathbf{1 0 6 , 6 6 0 . 6 0}$ & $\mathbf{7 7 , 6 6 7 . 0 0}$ \\
Land and Building Tax (PBB) & $9,461.19$ & $6,076.00$ \\
Rural sector & $(\mathrm{tad})$ & 31.66 \\
Urban sector & $(\mathrm{tad})$ & 125.26 \\
Forestry sector & $(\mathrm{tad})$ & $1,132.73$ \\
Mining sector & $(\mathrm{tad})$ & $3,408.09$ \\
Plantations sector & $(\mathrm{tad})$ & 379.27 \\
Share allocated to the level II & $(\mathrm{tad})$ & 999.07 \\
region by the central government & & \\
Duty on the acquisition of title to land or property & $32,000.00$ & 283.34 \\
Tax on Fuel for Motor Vehicles & $2,326.25$ & $1,624.16$ \\
\hline II. Non-Tax Profit Sharing & $\mathbf{2 , 1 4 5 . 0 0}$ & $\mathbf{2 , 0 1 2 . 3 5}$ \\
1. Forest Product Payments (IHH) & $2,100.00$ & $2,002.38$ \\
2. Granting of Title to State Land & 10.00 & 3.32 \\
3. Land Rent Profit Sharing & 30.00 & 6.65 \\
4. Fisheries Auction Profit Sharing & 5.00 & 0.00 \\
\hline
\end{tabular}


(PAD) from the forestry and plantations sector had been relatively small, consisting of groundwater and surface water utilisation taxes, uang sempadan; construction permits; and unloading fees levied on the transportation of timber products through ports. Law No. 18/1997 imposed limits on local government revenue-raising from the forestry and agro-industrial plantation subsectors through taxation and levies. This limits the sources of PAD from 12 to only six types of $\operatorname{tax}^{29}$ and from 25 to only 12 types of levy. ${ }^{30}$ One of the sources of PAD removed under this law was the levy on wood warehouses.

There was a perception amongst district and provincial officials interviewed for this study that Law No. 18/1997 limits the ability of the area to be financially independent. For the Ketapang district this translated into an estimated drop in PAD of Rp 400 million per year. The Ketapang district government has therefore even considered reinstating the regional regulations regarding taxes and levies that were removed under this law. Officials from The District Revenues Office (Dispenda) who were interviewed for this study asserted that that forestry and agroindustrial plantation operations are potentially substantial sources of regionally generated revenues (PAD). At the time this study was being conducted, the district DPRD was in the process of drawing up a regional regulation on the commercial regulation of timber products, whereby timber product trading in Ketapang, will incur local levies or taxes. The DPRD was also considering proposals to introduce a regional levy on each fresh fruit bunch (FFB) harvested from all types of oil palm plantations. This type of levy had previously been limited to largescale companies.

\subsection{DECENTRALISATION OF THE FORESTRY AND ESTATE CROPS SECTOR}

\subsubsection{Conflicts between stakeholders}

In Ketapang district, the task of coordinating the different interests of the stakeholders in forestry and agro-industrial plantation operations officially falls to the Badan Perencanaan Pembangunan Daerah or Regional Development Planning Board (Bappeda). This is a difficult task, as conflicts between stakeholders' interests are not uncommon. In the resolution of conflicts, regional interests (those of the district governments and the communities) are generally overridden. Many of the district level officials interviewed for this study claimed that the frequency of such conflicts indicated the need for decentralisation, or a transfer of some of the policy-making and administrative authority from the central to the district government. Previously, the benefits from forestry and agro-industrial activities went to the provincial government, under the control of the central government. They felt that increasing district-level authority over forestry resources would improve the opportunities for forestry and agro-industrialrelated benefits to be directed towards district-level socio-economic development.

\subsubsection{Vertical inter-agency conflicts}

Vertical inter-agency conflicts occurred between the Ketapang District government, and between the provincial government and provincial/central technical executive units (UPT) located in the district. The UPTs with responsibility for forestry and agro-industrial plantations in the Ketapang district include the KPH (District Forest Management Office), the Gunung Palung National Park Authority and the Plantations Branch Office.

Conflicts of interest between the district and provincial governments are centred on the allocation of land for forestry and plantation activities. The Ketapang district government complies with the District Spatial Plan (RTRWK) when developing the sector. When a private sector investor applies for a HPH timber concession or a HPHTI timber plantation concession, the local government administration, in this case, National Land Agency (BPN), will refer its decision to the provisions laid out in the RTRWK. However, in practice, it was not uncommon that the Bupati had to accept land allocations made by the Governor. District level officials interviewed for this study saw many of these allocations by the Governor as inappropriate and contrary to the provisions made in the RTRWK. In one case, the Bupati cancelled a private sector investor's HPHTI (timber plantation) location licence as there were no signs of any operations being carried out on the land allocated. However, the licence in principle (from the Minister of Forestry and Estate Crops) and the land use rights (HGU) (from the State Minister for Agrarian Affairs/head of the National Land 
Agency) remained in force because of a lack of coordination between the agencies. This situation indicates that there is a requirement for improved administrative coordination between the various levels of government administrative functions.

Conflicts that occurred between Bappeda and the Ketapang KPH Office (under the control of the Provincial Forestry Office) are centered on increasing regionally generated revenues (PAD). The Bappeda of Ketapang district asked the Ketapang KPH Office to focus on their PAD. On another hand, the KPH could not fulfill the task as they are formally under the Provincial Forestry Office, which is not one of the departments under the district's autonomy. The KPH Office is financially supported by the central (APBN) and provincial (APBD) government for their routine budget and program. For example, for the Budget Plan 1999/2000, realisation of routine budget in KPH Office was Rp 15 million that came from Kanwil Hutbun (8.5 million) and provincial Dinas Kehutanan (6.4 million). The Kanwil of forestry and plantation (Kanwil Hutbun) and the Provincial Forestry Office (Dinas Kehutanan) manage this budget and therefore $\mathrm{KPH}$ often had to run the program first and later the budget would be covered through a reimbursement procedure.

An official in the KPH office said that if the Ketapang district government asked for source of income for PAD from the KPH office, they had to invest through the district PAD allocation. In order to fulfill the requirement, the stated budget 1999/ 2000 was estimated at 150 million, but the Bappeda of Ketapang district disagreed and handed in the plan to Provincial APBD. The amount of budget allocated for forestry sector for the budget plan 1999/2000 was only 49 million. This was categorised in the district general development budget as Forest Monitoring Project and Distribution of Forest Products. In fact, the KPH Office could support PAD by implementing leges (Regional retribution) over the SAKB/SAKO (Permit to Transport Timber/Processed Wood Products) documents (now SKSHH or Permit to Transport Timber and Other Forest Products).

\subsubsection{Horizontal inter-agency conflicts}

The most prominent example of inter-agency conflict was between the forestry and industrial government administrative sectors. Forestry agencies commonly seek to impose limits on the growth of the wood processing industry, while industrial agencies' aims are to expand opportunities for new private sector investment in the district. An example of this is the fact that only seven of the 54 sawmills in the Ketapang district have active HPH (commercial forestry concessions) or IPK (timber clearance permit), but they have been issued with SIUP (sawmill operator's licences).

Another source of conflict is generated by the allocation of administrative authority to set and implement timber trade regulations. Under prevailing legislation, the responsibility for the regulation of trade in raw and unprocessed timber products is held by the Regional Forestry and Estate Crops Office or Kanwil Hutbun (an agency of MoFEC) and the Provincial Forestry Office (Dinas Kehutanan). A suggested resolution of this type of conflict was made by an official at the Regional Industry and Trade Office who indicated that the authority of the Ministry of Forestry and Estate Crops should be limited to upstream activities, i.e., to raw timber materials only, this would include the authority to issue permits to transport timber (SAKB). Downstream activities, i.e., wood processing and domestic and international timber trade, would be more effectively regulated by the Ministry of Industry and Trade through the Provincial Industry and Trade Office. At present, the latter agency is frequently unable to monitor transactions in the wood trade, as it has neither the authority nor access to necessary data.

The issuance of location licences for private sector timber plantation investment has also generated friction between the National Land Agency (BPN) and the Plantations Branch Office. For example the BPN issued one location licence for an 11,000 ha increase in a plantation area. The legally permitted maximum is 3,500 ha. For an increase of this size, a new operating license should have been obtained.

\subsubsection{Local community resistance}

There are frequent cases where local communities, particularly Dayak groups, resist forestry and agroindustrial plantation activities by external private 
sector timber investors. This resistance is motivated by their claims that these external investors' activities deny local communities' adat rights to benefit from forest areas. In cases such as these, where a settlement is reached, usually by involving the Dayak Adat Council (DAD), it generally involves some compensation to the local community, e.g., provision of roads, bridges, places of worship, schools and other physical infrastructure and facilities by the investor. However, there are also many cases where the local adat communities reject the offered settlement, maintaining their claim for the land in question to be handed over to the local community.

In addition to private investors holding $\mathrm{HPH}$ commercial forestry concessions and HTI timber plantation permits, PT. Inhutani II, timberprocessing companies (particularly sawmills) and agro-industrial companies have also experienced resistance from local community groups. This resistance included instances where local communities had directly taken over ex-HPH forest areas - which should have been controlled by PT. Inhutani II - by staking them out or turning them into demarcated lots. Sawmilling operations had also been affected by local community claims to adat rights over these forest areas, which are used as sources of raw material for processing. In this situation, companies (licensed or unlicensed) usually negotiate with the local residents, to buy and sell areas for logging. There have been instances where negotiations have failed and sawmill operators have found themselves subject to adat punishments.

In this environment, companies developing agroindustrial plantations in the Ketapang district have also experienced community resistance, particularly in the north where Dayak groups are relatively strong. These Dayak groups' resistance to plantation investors are motivated by the following beliefs: 1) modern agro-industrial plantations will lead to increased local poverty and because their access to land and forests will be limited; and 2) private sector investors are more interested in developing oil palm plantations, whilst the local community groups favour rubber plantations.

In the south, particularly in areas with a predominantly Malay ethnic population, there is less resistance to the development of oil palm plantations. Resistance has decreased as the ventures have become more successful. Here, there is interest amongst local communities in participating as oil palm farmers through the KKPA system. In the future, however, the KKPA system may well come into conflict with the legal provisions regulating the five plantation investment systems (see Section 4.2.1). ${ }^{31}$ Moreover, NGO representatives interviewed for this study claimed that companies would exploit the KKPA system as a means to gain access to land which over the local communities have claimed adat rights. The companies usually use the murni (sole operator) PBSN system. It is felt that this is because sole management by the investment company is simpler.

\subsubsection{Horizontal conflicts within the local community}

It is not unusual for overlapping adat claims to forest areas to result in disputes between communities. In these cases, the subdistrict head, supported by the Dayak Adat Council (DAD), will become involved in mediating between different groups. One such conflict occurred in 2000 between community groups in the subdistricts of Nanga Tayap, Tumbang Titi and Jelai Hulu over a (natural) ironwood forest on the borders of the three subdistricts. This forest was actually protected (by a gubernatorial decree) so that any felling of natural ironwood was a violation. When a group of Tumbang Titi residents felled 20 ironwood trees at the site communities in the two other subdistricts because they felt they also had adat rights to the forest, which would include felling rights. The three groups ultimately agreed not to exploit the ironwood forest, but to protect its sustainability by applying their respective adat laws as supervisory measures.

Other serious horizontal conflicts have occurred in relation to the Hutan Kemasyarakatan (Community Forest or HKM) project in the Gunung Palung National Park (TNGP) buffer zone. This project was designed by the Harvard LTFE (Laboratory of Tropical Forest Ecology) in 1994 to conserve the park's forests by involving 2000 families from the surrounding rural area. The 8,000 ha areas requested for allocation as Hutan Kemasyarakatan had formerly been allocated as 
HPH timber concessions held by Wanawati and Sumberjaya Baru Utama, which had both been turned over to PT. Inhutani II for rehabilitation. The Kanwil Office issued a temporary decree for the area to be turned over to the project. This resulted in conflict between the pro-HKM community groups and the anti-HKM community groups. One of the opposition groups included local private sector investors who had received large benefits from logging in the former HPH timber concession. They did not protest themselves, instead, workers employed in felling and who were economically dependent on the cukong (illegal wood entrepreneurs) were involved in protests. The members of community groups who had had no access to employment or benefits from the operation of the HPH timber concession were generally in favour of the HKM plans. The conflict reached its peak with the burning of the Lubuk Kuali camp and a member of the KSM (Kelompok Swadaya Masyarakat or Self-help community group) being assaulted.

\subsubsection{The different forms of decentralisation}

There is both formal and informal decentralisation in policy-making and administration of forestry and plantations activities in the Ketapang district. Formal decentralisation takes the form of government policy, centralised or local, with or without a clear legal basis. Informal decentralisation occurs at the regional level or at the community level and does not constitute government policy.

\subsubsection{Formal decentralisation}

A number of formal decentralisation processes in the forestry and agro-industrial plantations had or were taking place in the Ketapang district when this study was conducted. Formal decentralisation processes have been identified in the areas of reforestation and conservation, forest product exploitation rights, plantation investment patterns, and the zoning of plantation commodities.

The delegation of authority over reforestation and conservation to the district government has its legal basis in Government Regulation No. 62/ $1998^{32}$. Regional government officials interviewed for this study indicated that they saw this legal delegation more as the transfer of responsibilities from the centre to the region. These matters, at least in the short term, were seen as needing investment rather than yielding direct revenue for the region. As a result the regional government has not welcomed it with much enthusiasmevident from the fact that no autonomous office had been established to deal with these matters.

Other conspicuous decentralisation trends relate to the implications of the Decree of the Minister of Forestry and Plantations regarding the authority to issue concessions of up to 10,000 ha for governors and up to 100 ha for district heads. Local people responded positively to this Ministerial policy, thinking it would allow them access to exploit the forest. The Ketapang district government intended to direct HPHH concessions principally to former HPH concession areas, which were 'neglected' (because PT Inhutani II had not undertaken reforestation) and to production forest areas that were to be converted. Although this Ministerial Decree was subsequently postponed (by a Circular Letter from the Director General of Forest Protection), the Ketapang district government was already determined to put it into effect. The regional government saw the HPHH as an opportunity to restore traditional community rights to the forest, as well as being a potential source of regional revenue. In order to put the HPHH into effect, and in the interests of regulating illegal logging, the Ketapang district government issued Regional Regulation No. 26/2000 regarding the Management of Forests and Forest Products. ${ }^{33}$

This Regional Regulation grew out of, among other things, the regional government's desire to control illegal logging by allocating HPHH concessions. The regional government was optimistic that in this way, the management of forests and forest products would provide real economic benefits both for local communities and for the regional government, through regional revenue generation.

This optimism was clearly reflected in the forecast regional revenue targets from the forestry sector. The regional revenue target from the forestry sector for 2001 was Rp 36.74 billion, or $16 \%$ of the total regional revenue target for that year $(\mathrm{Rp}$ 231.45 billion). This figure was way above the forestry sector target for 2000 , which was Rp 1.57 
Table 16. Regional Revenue Targets and Realisation from the Forestry Sector, Ketapang District 2000-2001

\begin{tabular}{lcccc}
\hline Type of Revenue & \multicolumn{2}{c}{ Year 2000 } & \multicolumn{2}{c}{$\begin{array}{c}\text { Year 2001 } \\
\text { (Billion Rp.) }\end{array}$} \\
& Target & $\begin{array}{c}\text { Realised } \\
\text { (Dec 00) }\end{array}$ & Target $\begin{array}{c}\text { Rp.) } \\
\text { Realised } \\
\text { (Mar 01) }\end{array}$ \\
\hline IHH/PSDH & 1.5 & 1.87 & 7.37 & 0.68 \\
IHPH/IHPHH & - & - & 8.63 & - \\
DR (reforestation fund) & - & - & 20.74 & - \\
\hline Total & $1.57^{1)}$ & 1.87 & $36.74^{2)}$ & 0.68 \\
\hline
\end{tabular}

Source: Revenue Office, Ketapang District, March 2001.

1) $11 \%$ of the targeted Rp 13.92 billion.

2) $16 \%$ of the targeted Rp 231.45 billion

billion, or $11 \%$ of the total regional revenue target for the year concerned (Table 16). This very high revenue target for 2001 was certainly related in part to the change in the structure of revenue sharing between the regions and the centre (Law 25 Year 1999$)^{34}$.

The size of the target was linked in part to the measures taken by the regional government to implement decentralisation, in the form of the plans to realise HPHH and the control of processed timber products logged legally (IPKH/Wood
Processing Primary Industry) and illegally. The KPH Office in Ketapang district indicated that the revenue target for the district in 2001 from $\mathrm{HPHH}$ was $\mathrm{Rp} 12.02$ billion, and from the control of processed timber products, $\mathrm{Rp} 12.47$ billion. The total revenue from these two sources would be $\mathrm{Rp}$ 24.49 billion, or the same as the total target revenue from HPH (Table 17). There was even the possibility that this revenue would increase further, once estimates of revenue from the issuance of HPHH concessions and Forest Product Certificates (SKSHH) were included in the calculation of the

Table 17. Estimated Regional Revenue from the Forestry Sector, Ketapang District 2001

\begin{tabular}{|c|c|c|c|c|c|c|c|c|c|}
\hline \multirow{2}{*}{\multicolumn{2}{|c|}{ Source of Revenue }} & \multicolumn{8}{|c|}{ Type of Revenue (Billion Rp.) } \\
\hline & & $\begin{array}{l}\mathrm{IHH} / \\
\mathrm{IHPH}\end{array}$ & $\mathrm{PSDH}$ & DR & Auction & IPMDH & $\mathrm{HPHH}$ & $\begin{array}{l}\text { Leges } \\
\text { SKSHH }\end{array}$ & Total \\
\hline \multirow{3}{*}{$\begin{array}{l}\text { I. } \\
1 . \\
2 .\end{array}$} & $\begin{array}{l}\text { HPH \& HPHH } \\
\text { HPH }\end{array}$ & 5.40 & 8.19 & 23.04 & - & 0.15 & - & - & 36.78 \\
\hline & $\begin{array}{l}\left(250,000 \mathrm{~m}^{3}\right) \\
\mathrm{HPHH}\end{array}$ & 5.24 & 5.12 & 14.40 & - & - & - & - & 24.76 \\
\hline & $\left(150,000 \mathrm{~m}^{3}\right)$ & 0.16 & 3.07 & 8.64 & - & - & - & - & 12.02 \\
\hline \multirow[t]{2}{*}{ II. } & Control & - & 1.43 & 4.04 & - & - & - & - & 12.47 \\
\hline & $\begin{array}{l}\text { IPKH } \\
\left(60,000 \mathrm{~m}^{3}\right)\end{array}$ & - & 1.23 & 3.46 & 6.00 & - & - & - & 10.691 \\
\hline III. & $\begin{array}{l}\text { Logging } \\
\left(10,000 \mathrm{~m}^{3}\right)\end{array}$ & - & 0.20 & 0.58 & 1.00 & - & - & - & 1.78 \\
\hline \multicolumn{2}{|c|}{ Total } & 5.40 & 9.62 & 27.08 & 7.00 & 0.15 & & & 49.25 \\
\hline
\end{tabular}

Source: Revenue Office, Ketapang District, KPH Ketapang Estimate February 2001. 
target ${ }^{35}$. From these figures it is clear that for the Ketapang district government, forestry decentralisation was seen an opportunity to vastly increase regional revenue.

Others interviewed for this study were less optimistic about the potential of the HPHH concession system. This was based on experience of situations in which local communities had requested a HPHH concession for a forest area, which had frequently turned out to be already included in a HPH area whose licence was issued by the central Ministry of Forestry. In Sandai, for example, three large community groups (with about 100 families per group) own about 2,000 ha of forest. This forest contains damar (Shorea Javanica) trees, whose resin is sold by the local community groups. Because the price for damar is currently low, these groups are more interested in felling the wood and selling it, so they applied for a HPHH concession for this forest area. However, the area they claimed as community forest was also covered by a HPH concession held by a company in Jakarta ${ }^{36}$.

The public has welcomed what they see as good opportunities provided by the HPHH concession system. By the middle of 2000 , some 30 community groups had expressed interest in HPHH concessions and ten of these had filed proposals. In one sub-district, a community group had even erected demarcation markers around the ex-HPH concession area where they had applied for a HPHH concession. Some of these community group applicants are financed by local sawmill entrepreneurs. Nevertheless, it seems that it is not easy to get a 100 ha forest concession in the Ketapang district. The reason is that the $\mathrm{HPH}$ concessions, which are about to expire, have usually already been extended by the centre (MoFEC), leaving very little opportunity for the people of Ketapang to claim these areas.

In practice, the technical and operational costs of obtaining a licence for 100 ha of HPHH concession are high. In the Sintang district the cost can be as high as Rp 25 million (although the official cost is $\mathrm{Rp} 10$ million), which is a large amount of money for a local community to raise. One way to meet this cost is to enter into an agreement with a largescale HPH concession holding company. This gives rise to a 'cooperative system' whereby the local community apply for a HPHH concession, backed by a private sector company. This enables large-scale HPH timber concessionaires to benefit under decentralisation from a scheme aimed at developing local community's socio-economic opportunities.

In the plantations subsector, the Ketapang government had plans to zone plantation crops under the RTRWK in order to avoid developing large areas of land under monoculture plantations. One reason for this was that a recent locust infestation in the area was partly attributed to the expansion of oil palm plantation in the southern part of the district. Thus, in line with the local communities' wishes, Bappeda was seeking investors interested in developing rubber plantations. In the north of Ketapang district, there are a number of location licences that cannot be put into operation because of local resistance, both because of the type of crop and because of an inappropriate investment system. Some of the local government officials interviewed for this study saw the people's resistance as a means of support to help them prevent the over expansion of oil palm plantations. In fact, the zoning of plantation commodities planned by Bappeda includes plans for oil-palm plantation in the southern part and rubber plantation in the northern part.

\subsubsection{Informal decentralisation}

One of the most obvious examples of informal decentralisation in the Ketapang district, particularly since 1998, has been illegal logging carried out by members of the local communities, paid by local and non-local entrepreneurs. The local community sees illegal logging as a manifestation of its adat traditional rights to forest resources, which they feel have been marginalised by the allocation of large-scale HPH concessions to private sector companies from outside the region. When entrepreneurs who hold no concession over an area give members of the local community illegal access to the forest, although they are only hired to fell and transport the timber, this is seen as an opportunity to restore traditional access to forest resources.

Illegal logging is carried out by small groups of 
4-8 people or large groups of $10-20$ people. The most experienced loggers use chainsaws and understand felling techniques; they generally come from Sambas. The wood sawyers are hired from the local community, while those who transport the wood (along small tracks) are recruited from other areas - this is because if local people were used, they might move the timber to their own homes. The logging group obtains a loan from the head of a local group, which is funded by an entrepreneur from outside the area (cukong/tauke). This cukong or tauke is usually connected to the sawmill entrepreneurs in Ketapang or other areas in West Kalimantan.

Research by the Harvard LTFE and the Director General of Forest Protection in 1998 shows that, under the logging system described above, loggers are paid based on the amount of timber they fell, with a floor price of about Rp 50,000/ $\mathrm{m}^{3}$. The head of the group (the local boss) will take the workers' loans out of the total value of the felled wood, which means that the loggers generally receive only about $\mathrm{Rp} 75,000-\mathrm{Rp}$ 150,000 for three weeks' work in the forest. The head of the group then sells the wood to the tauke for between Rp 100,000 and Rp 150,000/ $\mathrm{m}^{3}$ and the tauke sells it to the sawmill for about $\mathrm{Rp}$ $250,000 / \mathrm{m}^{3}$. The price of the processed illegal wood when it leaves the sawmill for the local market (and sometimes for the international marketplace) is about $\mathrm{Rp} 500,000 / \mathrm{m}^{3}$. To the consumer, the price of this wood-balaul bangkirai (Shorea laevis), for example-can reach $\mathrm{Rp} 1.5 \mathrm{million} / \mathrm{m}^{3}$.

Although no precise figures are available, the local government and Ketapang KPH personnel interviewed for this study believe that very high quantities of timber are being extracted by illegal logging in the district-from the Batu ampar KPH (in the north) and the Ketapang KPH (in the south) areas. It is estimated that one cukong (tauke) can obtain about $1,000 \mathrm{~m}^{3}$ of wood per month. ${ }^{37}$ With as many as 100 cukong in each northern watershed (Pawan, Siduk, Air Hitam, etc.) illegal removal could be as much as $100,000 \mathrm{~m}^{3}$ of wood from the forest each month. These figures could be an overestimation; but they do indicate that in the last three years, the volume of illegal timber extracted was very high.
An important factor in the increase of illegal logging in this area was the scarcity of raw materials resulting from a rapidly expanding wood processing industry in West Kalimantan during the $1980 \mathrm{~s}$, following Indonesia's ban on the export of unprocessed logs. Both HPH concession holders and non-concession holders may become involved in hiring local community members to $\log$ areas for which they hold no concession. HPH concession holders may also log illegally within their own concession area in violation of the annual management plan, or RKT, to overcome a lack of raw timber to supply the local plywood industry or to gain access to logs at a lower price. Illegal logging by non-HPH entrepreneurs is usually carried out to meet the high demand for wood from the housing and furniture-making industries.

Non-HPH entrepreneurs carry out illegal logging in several types of forest area including ex-HPH areas (under the authority of PT. Inhutani II), protected areas (TNGP and other nature reserves and protected forests) and even active HPH areas (in some cases with the knowledge of the site manager). Illegal logging can also occur in ex-HPH areas. As PT. Inhutani II does not have the capacity to effectively manage reforestation in all areas, there is little surveillance and therefore few risks involved in illegal logging. The nature reserves most seriously damaged by illegal logging are Kendawangan and Karimata, which open onto the Java Sea, making it easy to transport illegally harvested timber.

A large number of people benefit economically from illegal logging. The greatest benefits accrue to the cukong/tauke who invest in these activities, because they get cheap raw materials for their businesses and/or they can sell the wood without having to pay the usual fees and taxes (particularly Land and Building Tax), Reforestation Funds (DR), Forest Products Payment (IHH), the costs of Permits to Transport Timber (SAKB) and Permits to transport Processed Wood Products (SAKO). There are informal costs involved but, according to a large-scale entrepreneur in the Ketapang district, these are less than the formal costs.

Local communities, in addition to being employed as loggers, have also been 'creative' in their efforts to secure a share of the economic benefit derived 
from illegal logging activities by claiming certain areas of forest as community-owned forest. An illegal logging tauke then buys the wood from a certain piece of forest in bulk for a price of about Rp 35,000-Rp 50,000 per $\mathrm{m}^{3}$ of wood, depending on the distance from transportation routes. After clear-felling this forest area, the owner(s) will burn it so it can be used as a rubber plantation.

Another beneficiary from illegal logging, is the cargo shipping industry. Ships owned by Ketapang entrepreneurs routinely sail between Ketapang and Semarang, Tegal, Cirebon and Jakarta/Sunda Kelapa in Java, taking wood from the district (usually from illegal logging without SAKO/ SAKB documents) and returning with a cargo of the 'nine essential commodities' (sembako) needed by local people. Transportation of wood from Ketapang is much more profitable than the transportation of sembako from Java. Without a wood cargo, shipping operators would not be willing to sail to Java as it would be unprofitable.

Therefore, the shippers are a vital link in the illegal logging chain. Without the support of sea transportation, illegal logging would decline because the local market could not possibly absorb the large amount of wood produced. One source interviewed for this study estimated that as many as five ships leave Ketapang district every day with a cargo of around $300-400 \mathrm{~m}^{3}$ of illegally harvested timber. (It is said that each ship is provided with Rp 8-10 million by the cukong to be used to cover informal costs that might arise should any arrest or inspection occur). With 20 shipping days each month and nine shipping months in one year, this means that as much as $270,000-360,000 \mathrm{~m}^{3}$ of wood from illegal logging could be taken out of the Ketapang district each year.

The local government officials interviewed for this study were aware of the vital role that sea transportation plays. In one effort to eradicate illegal logging in 1999, a local government operations team attempted to close all ports in estuaries or small bays that were transport points for wood from Ketapang. These ports included Jelai, Air Hitam, Rantau Panjang, Pulau Maya, Teluk Batang, Balai Bekuak, Kendawangan, Teluk Melano and Pawan. As a result of this action, ship operators stopped sailing both to and from Java-Ketapang ships were unwilling to sail to Java without a cargo of wood, while the ships in Java were unwilling to bring sembako because there would be no timber cargo on their return trip. Without these shipping activities a serious scarcity of sembako developed. Local government attempts to acquire sembako from Pontianak failed to overcome the shortages and discontent arose among the local communities. As soon as the operation to 'close' the points of exit for wood ended, ships started sailing again and at the same time the supply of sembako to Ketapang resumed. There was no official statement from the government, but ship operators and some local officials stated that there had been pressure in the form of a threatened boycott on transporting sembako from Java to Ketapang if the operators were not allowed to transport a cargo of (illegal) timber to Java.

The Ketapang district government suffers the greatest loss from illegal logging. These activities do not make any contribution to the PAD, except indirectly through the taxes and levies imposed by the companies in the wood processing industry and shipping companies. Local officials interviewed for this study regarded illegal logging as a process of large-scale 'forest resource asset flight' from the Ketapang area. With one estimate putting the volume of illegal timber exports at least $270,000 \mathrm{~m}^{3}$, which indicates that the losses in Forest Resource Rent Provision (PSDH) could be as high as $\mathrm{Rp} \mathrm{30,000} \mathrm{per} \mathrm{m}^{3}$, which would mean that the state could be losing income of up to $\mathrm{Rp} 8.1$ billion per year. As already noted, the local government plans to levy charges for unofficial logging, through the allocation of $\mathrm{HPHH}$ concessions and this is expected to contribute significant amounts of income to the PAD. Forestry agencies have been strongly opposed to this approach because it is seen as an endorsement of illegal logging, which will stimulate over-exploitation and threaten the sustainability of the forests in the Ketapang district. In contrast, the illegal timber entrepreneurs and shipping operators have greeted the these plans with enthusiasm as they see it as a means of continuing their operations, for which they would be willing to pay levies and fees under the HРHН concession scheme to the government. 


\subsection{RESPONSE TO THE ISSUE OF DECENTRALISATION}

\subsubsection{Local government response}

The Ketapang district government has enthusiastically welcomed decentralisation, particularly in relation to the opportunities for autonomy in the forestry and agro-industrial plantations sector. This enthusiasm is founded on a desire to increase PAD in order to finance regional autonomy. The district government officials interviewed for this study believed that the greatest economic potential and source of PAD for the Ketapang district lay with its forest resources and plantation development capacity. However, up to now the exploitation of forest assets by HPH entrepreneurs has not demonstrated a significant contribution to the economic development of the region and its people. In theory, a portion of the income from these assets should come back to the district in the form of a share of the PBB, IHH and DR received from higher government agencies but, in practice any amounts involved are relatively small. In fact the Ketapang district government has never received any share of DR. HPH concession holders cannot be asked to contribute directly to the regional treasury, because the authority to distribute local revenues from this source belongs lies with the Ministry of Forestry and Estate Crops (IHH/DR) and Ministry of Finance (PBB). To date, the HPH concession holders have made no direct contribution to local revenues, although the district government is obliged to safeguard HPH concessions and to prevent environmental damage, including the declining quality and flow of the rivers associated with timber clearance on HPH concessions.

There was a perception amongst district officials interviewed for this study that the central government is not wholly committed to implementing autonomy. Government Regulation No. 25/2000 (related to the implementation of Law No. 22/1999) does not provide for the complete decentralisation of forestry matters to the district level, since it only gives a clear definition of the provincial government's authority in this area. When the Minister of Regional Autonomy declared that details of the regional autonomy process should be worked out by the district governments themselves, at the time this study was conducted, the Ketapang district government began drafting and was pushing to obtain 28 types of authority over forestry and agro-industrial plantation activities. Thirteen of these are directly related to the following forestry activities:

1. Forest inventory and mapping.

2. Designating and safeguarding borders for production forest and protected forest.

3. Implementation of the regulation of forest borders, reconstruction and regulation of borders for production forest and protected forest.

4. Management of district forest preservation.

5. Rehabilitation and reclamation of production forest and protected forest.

6. Licensing within the district/municipality, including utilisation of wood forest products, utilisation of unprotected flora and fauna, plantation businesses and management of forest products.

7. Supervision of germination, fertilisers, pesticides, equipment and machinery in the forestry and estate crops sector.

8. The implementation of monitoring of predicted organic pests and integrated pest control for forestry and plantations crops.

9. Implementation and supervision of rehabilitation, reclamation, silviculture, cultivation and management systems.

10. Implementation of sustainable forest park management in the district.

11. Stipulation of guidelines to determine the rates of cross-district levies on NTFPs.

12. Active implementation, in conjunction with the province, of the delineation of areas and changes to the function and status of forests in respect of planning land use in the district.

13. Protecting and safeguarding of forests in the district.

In addition to this list of requested authorities, the Ketapang district government had also started planning the organisation and management of the new administration. These plans included the formation of a district-level Forestry Office and Forestry Branch Offices at the subdistrict level. Another proposal is to merge the forestry agency $(\mathrm{KPH})$ at the district level with the agriculture agency to become the Agriculture and Forestry Office. This proposal carries a significant risk of 
conflict with the provincial government because the Provincial Forestry Office itself prefers the establishment of a provincial-level Forestry Branch Office with UPT status at the subdistrict level, which would be under the authority of the provincial Forestry Branch Office. The Provincial Forestry Office appears unwilling to relinquish control over forest areas in the district, while the district government wants to implement structures which would give them more direct authority.

The Ketapang Bupati identified the actual decentralisation and devolution of authority to the districts as the major difficulty with autonomy and decentralisation. This was more of an issue than any specific difficulties related to financial personnel and technical capacity. He acknowledged that if the district government can secure these responsibilities - and it will be a challenge - this would have to be followed by a period of learning related to their implementation.

While the Ketapang district government's primary interest in decentralisation is with securing autonomy in the forestry sector, Law No. $22^{38}$ makes no mention of this area. However, officials at the Regional Forestry and Plantations Office indicated that the administration of forests would be best left - initially at least - under the authority of the provincial level, which, they felt had the necessary professional capacity for this task. They also indicated their opinion that devolution of authority to the district-level should be carried out in stages to give time for district administrative institutions to build capacity. According to one Provincial Forestry Office official, a strong district-level Forestry Office is necessary to implement authority effectively. District institutions must first be strengthened. Once this has happened, then, he said the provincial level government should be restricted to policy-making.

Control over the management of forestry resources as a PAD source is not the only authority sought by the Ketapang district government. It also sees the decentralisation of non-forestry resource management as a potential means of increasing PAD. Such resources, including gold mining and sea (estuary) sand quarrying are expected to provide considerable income for the region, if they can be self-managed. Gold mining is currently unlicensed (PETI or Penambang Emas Tanpa Ijin) and therefore yields no official revenues for the regional treasury. On the contrary, these PETI activities have resulted in environmental damage, which will cost the government a lot to repair. This situation of ineffective regulation of gold mining has arisen because the Ministry of Mines and Energy, despite having the authority, is not active in the field. The sea, and particularly the estuaries in the Ketapang region, hold sand extractives that are estimated to be worth hundreds of billions of rupiah. A Bappeda official estimated ${ }^{39}$ that the value of this sand could be as high as $\mathrm{Rp}$ 1 trillion, or the equivalent of the Ketapang regional budget for about 10 years. The head of Bappeda and the Ketapang district head believe that if the income from sand quarrying can be realised, there would be no need to exploit the forest to finance regional development, at least not for 10 years.

\subsubsection{Response of the private sector}

The private sector representatives interviewed for this study viewed autonomy as a possible way of eliminating conflicts of interest between the government and local communities. At present private sector forestry entrepreneurs see the regulations on forestry and timber as being out of step with the communities' situation on the ground. For example, industrial agencies have issued licences for the development of small-scale timber industries (construction materials, etc.) to local community groups, but the forestry agencies had been unwilling to issue Timber Clearance Permits (IPK), which would have been required to guarantee a supply of raw materials for these smallscale enterprises. Consequently, small-scale timber entrepreneurs have faced difficulties in acquiring raw materials legally. The representatives interviewed for this study indicated that they would be willing to comply with the regulations and pay the relevant fees and levies if they were given a permit.

Because of the difficulty of acquiring raw materials legally, small-scale timber entrepreneurs may often resort to illegal logging. Regional autonomy is seen as an opportunity to develop local policies to regulate and secure legal access of small-scale enterprises to raw materials. It is hoped that the DPR (Legislative Assembly) will enact regional 
regulations over log felling by the community, partly by imposing costs (levies and taxes) to be paid to the district government. The illegal timber entrepreneurs interviewed for this study indicated that official regulation would be acceptable as it would increase security and stability for their operations. They indicated that this might limit their susceptibility to informal requests for payments by some members of the government and security apparatus.

The forestry agencies in general do not agree with the idea of regulating (or effectively legalising) illegal logging. Therefore they continue to apply the old approach to handling illegal logging: 'seize and auction'. Such seizures are usually illegally felled timber that has entered an industrial location without documentation. According to the KSDA, the forestry agencies are often reluctant to arrest members of local communities involved in illegal logging activities, due to the threat of fierce community resistance.

Small-scale timber entrepreneurs interviewed for this study disagreed with the forestry agencies' stance that 'the people are destroying the forest through illegal logging'. They argued instead that the felling technology used for small-scale timber extraction is relatively basic, and therefore causes far less destruction than the industrial methods used in HPH concession areas. They also made the case that the methods of transportation of timber used for small-scale unlicensed timber extraction causes less damage than the heavy equipment used by large-scale HPH concession holders. Wood is dragged from the forest along tracks to the main roads and then taken to the river. It is then brought to the subdistrict town (usually on an estuary) or to Ketapang (along inland waterways or by sea), from where it is shipped to Java. Because of this transportation system, illegal logging usually stops or diminishes during periods of low water levels (June to August). At these times the loggers will commonly support themselves by taking loans from the cukong, which are repaid when water levels rise again.

The documentation required for legal timber harvesting includes SAKB and SAKO permits, as well as proof of payment of IHH and DR fees. Individuals interviewed for this study indicated that a significant amount of the timber transported to Java did not usually have the relevant documentation. They also said that if this timber is intercepted in Java, the port authorities usually just impose a fine. One entrepreneur's estimate was that the total (informal) costs incurred by timber entrepreneurs operating without the relevant documentation between the forest and Java are about the same as the official cost of paying for SAKB/SAKO permits and IHH/DR fees. Thus, many of the entrepreneurs interviewed for this study would prefer to be involved in officially regulated timber harvesting which would mean that the local government's sources of official revenue would increase. 


\subsection{DAYAK ADAT COMMUNITIES}

At the regional level, the focus on decentralisation has been primarily concerned with the transfer of authority from central to provincial and district governments; the issue of authority being transferred from these governments to local communities has not yet been considered. The issue of granting to local communities a degree of autonomy, particularly with respect to the adat communities rights to land and forest resources has received little attention in the discussions relating to decentralisation. The case of the Dayak adat communities in the Ketapang district illustrates local people's efforts to secure what they see as their rights over land and forests. This type of situation consitutes a de facto form of decentralisation.

\subsubsection{Dayak adat communities and their land}

The Dayak are indigenous to the Ketapang area. 'Dayak' is a collective name that encompasses hundreds of ethno-linguistic groups on the island of Kalimantan, and inherent in its meaning is a rich and diverse range of cultural elements.

Djuweng (1996) described the Dayak as an oral people. It is through their oral traditions that this ethnic group has identified itself as an autonomous and distinct group. This tradition is also how a Dayak tribe identifies itself as part of a collective whole. Their oral tradition encompasses their basic concepts of ideology, philosophy, history, language, literature and social structure, as well as the Dayak peoples' way of relating to the natural and supernatural worlds. The Dayak characteristically have an integral relationship with natural eco-systems. Many sub-tribes share this same concept of the inextricable inter-relationship between humans and the land and the natural resources on it. In the context of a sub-tribe, ownership of a specific area the land will be claimed as an adat law unit. This area is often called a binua (by the Kanayan group), manoa (Iban) or banua (Simpang, Laur, Jeka, Krio Lara and Bakati). The concept of a banua is geopolitical. Within the boundaries of the banua there is land with assets in the form of natural resources. The people living within a banua are governed by a set of adat rules (laws), and individuals are chosen by the people to enforce these rules. The method of land use management within a banua can be compared to a collective, indigenous integrated farming system. There are at least seven components in this system (Djuweng 1996).

1. Forest areas protected or reserved for the future. Individuals are free to take products (by hunting or collecting wood for personal, noncommercial use) from these areas. They are collectively owned by the adat law community. Members of other adat law communities are allowed access to products after receiving permission from the local community. The Dayak community recognises adat-owned forest or customary forest. This forest has cultural, ecological, political, social and economic functions. There are sacred places, where the forest's sustainability is carefully guarded. The forest provides a natural ecological equilibrium by functioning as a buffer and regulator of water and heat (rain, climate and weather). There are also individual and collective rights to honey bee trees, damar (Shorea Javanica) trees and ironwood. This is also where construction materials are found. There can be agreement that the forest will become a cultivated area in the future. It is also a hunting area, and the source of many kinds of vegetable and medicinal plant. 
2. Land planted with fruit trees. This land usually belongs to an individual but when the fruit is ripe and falls from the tree, anyone is entitled to collect and enjoy it. In this case, there is a combination of individual and collective ownership.

3. Land planted with rubber trees, coffee, pepper, cocoa and other tree crops. This land belongs to the person who plants the trees/crop. The land and plants growing on it may be inherited by descendants or become collectively owned. In many places, rubber plantations are the mainstay of the Dayak community economy.

4. Agricultural land. There are two types of agricultural land: land in use and fallow land. Dayak people understand the sustainable exploitation of natural resources. The original agricultural methods of the Dayak have a 5-15 year cycle, to allow plants to regenerate.

5. Burial grounds and sacred land. Burial grounds are collectively owned. Sacred land, on which there are holy places of worship, are also collectively owned. This land cannot be cultivated and the wood on it may not be collected.

6. Village land. This consists of individual homes and gardens with areas for livestock (chicken coops and pigsties).

7. Rivers and lakes for fisheries. These are owned collectively and no one is allowed to stake an individual claim to the ownership or control of these assets.

In summary, for Dayak communities, the land holds their unwritten history, and a link with their ancestors. It is a foundation for their present-day lives and something to bequeath to future generations. The land links the past, present and the future (Djuweng 1996).

\subsubsection{HPH concessions and illegal logging}

The Dayak have been affected by the impacts of 'development' or modernisation, which have been primarily introduced by central government policies and programmes. In the forestry sector, the issuance of HPH concessions to large-scale entrepreneurs from outside the area has had farreaching impacts on the local communities, particularly the Dayak. HPH concessions have been allocated for large areas of forest land, dividing up the traditionally managed forest into lots, which has made it difficult for local communities to continue their traditional forms of access to, and use of forest resources. A Dayak community representative at the provincial level explained that this process effectively makes his people 'the outsiders'. The process of allocating concessions granting the right to exploit forestbased resources to external private sector and state companies, has effectively led to the take-over of forest areas which were traditionally collectively managed under adat systems. This has in the past led to the Dayak people's eviction from their native homes, in the interests of developing industrial forests and large-scale agro-industrial plantation projects. Local adat claims to land use rights have not been recognised by the central government. Many community representatives interviewed for this study felt that local communities' being marginalised by successive central government policies and regulations, which introduced and implemented to meet the needs and interests of large-scale state and private enterprises, rather than the needs of local communities.

As a result of this situation, government administrative functions at all levels will commonly be in conflict with the adat community. Moreover, the duties, objectives and levels of resourcing of the forestry institutions, from provincial to district level, indicate that the government is more oriented to promoting profitable short-term production and exploitation, than sustainable long-term management of the forest resources. For example, the units that have been set up specifically to preserve forest areas (protected forest or national parks), such as the KSDA Unit, have neither the political nor the budgetary support to enable them to function effectively. Whilst the local communities have been implicated by some officials in government as being responsible for environmental degradation through illegal logging, one of the most successful timber-transporting entrepreneurs in the Ketapang district stated that members of the local community are actually merely labourersone link in the illegal logging chain. It is also 
evident that their involvement in illegal logging is stimulated by their belief that this constitutes an opportunity to gain a share of the benefits accrued from the exploitation of forest resources, which they continue to see as traditionally owned by them under adat law.

\subsubsection{Participatory mapping}

A matter that is frequently discussed in the context of community involvement in spatial planning is the need for forest areas to be more clearly demarcated; to help resolve some of the conflicts between adat, state and corporate rights over forest land. Local communities and NGOs working on their behalf believe that this process will involve greater recognition of adat rights and more access to processes of boundary setting for local communities. An initiative by one NGO (PPSDAK Pancur Kasih Pontianak) involved participatory mapping, which aimed to clearly identify the nature and extent of the adat community's role in land use.

Participatory mapping is a method of map-making that combines modern maps (topographical maps, aerial photography and satellite imagery) with the adat community's mental maps for traditional land use. Combining these two types of map creates a land use map (of a specific territory or kampung) that is agreed as accurate by all the stakeholders involved in the process.

These maps are also very useful in a practical sense, because they also allow comparisons to be made between the local government's Regional Land Use Plan (RTRW), the 'harmonised map' and the allocations of land based on the community's interests illustrated in the participatory map. Public information processes about the planned allocations of land and strategies for development that are contained in the 'harmonised map' should also involve feedback based on the participatory map. This level of input has not been reached, as consultative mechanisms have yet to be developed to the stage where the local community's interests are considered as a matter of course during land allocation processes. These efforts must be accompanied by other initiatives to stimulate the creation of land use allocation maps that are both more transparent and equitable.

\subsubsection{Forest product collection rights}

Forest Product Harvest Concessions (HPHH), are regulated under Regional Regulation No. 6/1999.40 There were no implementing guidelines for this regulation until the issuance of the Decree of the Minister of Forestry and Estate Crops No. 310/ 1999 regarding HPHH concessions. This decree gave individuals or groups the rights to legally use timber and NTFPs from a maximum area of 100 ha for a period of one year, with the permission of the Bupati. ${ }^{41}$ However, although numerous applications by local communities submitted the Ministry of Forestry and Estate Crops subsequently issued a new decree canceling the district-level authority to issue HPHH concessions.

This situation resulted in local level conflicts over timber exploitation rights. For example, in the Sundai Ketapang subdistrict a community group had applied for a HPHH concession over a former HPH concession area whose licence had been revoked. The local community declared that this area was rightfully theirs under adat law and had been unlawfully seized by the government. At the same time, the Minister of Forestry and Estate Crops had classified this area as a new HPH (PT. Karunia Hutan Lestari) amounting to 41,700 ha. ${ }^{42}$ The Ketapang district government was unaware of this central allocation of a HPH concession until after the submission of the Environmental Impact Assessment report on the area. This case emphasises the lack of co-ordination and integration between the district, provincial and central governments and indicates that greater co-ordination and clarification of roles is required to achieve effective regional autonomy. The Bupati and the DPRD believe that district government should retain the authority to issue HPHH concessions, because this provides local communities with small-scale economic development opportunities. At the time this study was conducted, this issue was yet to be resolved.

This unclear division of roles, authorities and responsibilities between the various levels of government creates uncertainty over the future management of forestry resources, and increases the risk of conflicts of interest between different stakeholders. In a situation where different levels of government are issuing concessions over land with little co-ordination between them, it is likely that these allocations will overlap, or that the 
amount of land available for new allocations will be limited. This situation could increase the pressure on conservation forest areas and the national park. These uncertainties indicate that under decentralisation, the struggles over these interests are likely to continue and could even intensify in the future.

Some commentary offered by individuals interviewed for this report indicated that this uncertainty is partly caused by the fact that regional officials view autonomy only in terms of the decentralisation of administrative functions; and as and the need to increase local revenues. This focus has excluded consideration of the wider implications of decentralisation processes, such as how decentralisation will take account of the interests and needs of local communities.

The key question in this province is whether the authority to issue HPHH concessions - as a type of formal decentralisation of authority to the district level - will exacerbate the destruction of natural resources, which would in turn be detrimental to the region and the people themselves.

\subsection{AGRO-INDUSTRIAL PLANTATIONS}

The situation in relation to plantation activities in West Kalimantan in general and in Ketapang District in particular was described in Sections 2 and 3 . This section focuses on the specific impacts of decentralisation processes on the plantations sector. In the Ketapang district, decentralisation is likely to have an impact on the implementation of plantation investment systems; licensing for plantation investments (particularly location licenses); specification of crop types (rubber or oil palm); and the potential of plantations as a source of local revenues (PAD) for the district government.

\subsubsection{Plantation investment systems}

In order to promote local-level economic development, the Minister of Forestry and Estate Crops issued a decree in 1999 outlining five investment systems for the plantations sector. ${ }^{43}$ These systems take the form of the following private and community partnerships (cooperatives):
1. Plantations Business Cooperative (KUP): $100 \%$ of the shares are owned by a cooperative.

2. Cooperative-Investor Joint Venture (PATKI): $65 \%$ of the shares are owned by a cooperative and $35 \%$ by a private investor.

\section{Investor-Cooperative Joint Venture (PAT-} IK): $80 \%$ of the shares are owned by a private investor/company and at least $20 \%$ by a cooperative, and this share will be increased in stages.

4. Build, Operate and Transfer (BOT): a private investor/company carries out the development and operations for a certain period, after which the project is transferred to a cooperative.

5. Bank Tabungan Negara (BTN): a private investor/company develops the plantation or factory, after which it is transferred (sold) to an interested party/the owner, who is member of a cooperative.

Personnel at the Plantations Branch Office and Bappeda who were interviewed for this study regard the investment systems outlined in the decree as lacking relevance to the social and economic situation of communities in the district. Firstly, these investment systems rely on the existence of strong cooperatives, which will be difficult to develop in Ketapang district. Given the distances between villages, it is not easy to form cooperatives among rural Dayak communities. The requirement for cooperatives has therefore been a disincentive to potential investors in the plantations sector. Secondly, these investment systems require individual ownership of shares by members of cooperative. This concept of share-ownership is unfamiliar to the Dayak whose concept of rights over land use involves collective rights over land, and not the outright individual ownership of shares in forest land.

This study also identified concern among NGO representatives interviewed, that the community members could be open to exploitation by private sector investors, as the Dayak have little experience in the application of such systems.

Because these investment systems were seen to be inappropriate, the provincial Plantations Office decided to continue to apply Presidential 
Instruction (Instruksi Presiden or Inpres) No. 1/ 1996 regarding the development of plantations, since the authority of a Decree of the Minister of Forestry and Estate Crops is below that of a Presidential Instruction. This instruction provides for plantations under the four systems outlined in 3.1.2.2: Swadaya (self-sufficiency), People's Core Plantation (PIR), Development Service Unit (UPP) and Private National Large-Scale Plantations (PBSN). This last system can be either murni (sole operator) or in partnership with the community (KKPA).

Regional plantations agency staff interviewed for this study indicated that they always stress the importance of developing partnerships with the community to prospective investors. In addition to this, the location licence document for plantation investments issued by the Ketapang BPN office explicitly recommends that a) the investor involve the community as participants/owners in the plantations, and/or b) the investor develop a plantation for the community members participating in the program. At the provincial level, the Plantations Office and Regional Investment Coordinating Board (BPKMD) ask the investor to enter into a legally binding commitment to the effect that, as part of the process of implementing the investment, he/she will involve members of the community by establishing a cooperative for them. Without this written commitment, the plantation investment application will not be processed.

Despite these mechanisms to safeguard community interests, to date, the development of Private Large-Scale Plantations (PBS) has commonly resulted in restrictions on the community's access to the land. In Ketapang district, this has resulted in conflicts between private sector investors' and communities' interests, particularly in relation to the release of titles to land. If a private investor is given a Land Use Permit (HGU), the local communities commonly regard this as a 'loss of land'. Private sector investors view the acquisition of a clear title to the land as essential, if they are to make an investment.

Under the Members' Primary Credit Cooperative (KKPA) system, members of the community acquire guaranteed ownership of shares in the plantation through a credit scheme. However, one problem associated with this system is that companies often experience difficulty with finding banks willing to lend the capital for the KKPA. Another problem identified by the NGO representatives interviewed for this study is the risk that, in practice, the system can be used by private sector companies to gain access to land for commercial plantation development and could effectively result in the loss of adat community land rights. In Manis Mata in Ketapang district, PT. Harapan Sawit Lestari applied the KKPA system in 1995 in order to develop a plantation on about 2,000 ha of the local adat land. Without consulting the community, the company then changed the status of the land title from 'traditional right to land' (hak ulayat), by acquiring a Land Use Permit (HGU), which enabled the company to legally claim 'ownership title through the granting of a title to state land'. This action provoked conflict with the local community, who took action by occupying and taking control of the oil palm plantation managed by the company.

Under the KKPA system, a company is sometimes simply not able to develop the plasma plantations for the participating farmers. This is the case where for example, the land available is not suitable for plantation development, where the soil contains high quantities of quartz sand or kaolin. In such cases, community participants who have already 'given up' their land for the plantation have protested. In order to avoid this type of protest, the Ketapang government and the plantation companies in the district created an emergency system known as the "core plantation loan and use system'. Under this scheme, the company lends a part of the 'core' plantation to the participating farmers who have not received 'plasma' land. When the plasma plantations are available for the farmers who have borrowed land, the core plantation reverts to the company. This system was developed to prevent instances of conflict between the participating KKPA farmers and the private sector companies involved in plantation development in the area.

A desire to prevent this type of conflict can motivate the local government to take steps that actually conflict with standard legislation. For example, in the case of one Transmigration-PIR 
unit, the plantation was already in production, the participating farmers had yet to receive the land allocated to them under the agreement. The participating farmers demanded that the entire plantation be transferred immediately to them. This demand was accompanied by threats that the plantation would be damaged or burned if the company refused to comply. To avoid this difficult situation, the head of the Plantations Branch Office in Ketapang asked the company to distribute the plantation land to the participating farmers through 'profit sharing', whereby the responsibility for maintenance and harvesting was transferred from the core company to the participating farmers. The provincial Plantations Office finally approved this measure due to a fear that the plantation might actually be destroyed.

\subsubsection{Location licences for plantations}

Investors wishing to put capital into the plantations sector in the Ketapang district must comply with a number of procedures:

1. The investor first must obtain a land allocation from the governor, with a maximum of 20,000 ha of land per district.

2. After being allocated the land, the investor must arrange a location licence from the National Land Agency (BPN) office in the district.

3. Based on the land allocation and the location licence, the investor then obtains an investment licence from the Regional Investment Coordinating Board (BPKMD) in the province.

4. Having completed the first three steps, the investor arranges a plantation licence in principle from the Directorate General of Plantations (in this case the provincial Plantations Office).

Although the authority to issue location licences was transferred to the Bupati from the Governor under the October 1993 Policy Packet. As is the case with the issuance of concessions over forestry land (see section 2.2.1.1. Forest area land use and management), in practice, the Governor also still retains a degree of control over the issuance of plantation licences.

However, there has been an instance in which the Ketapang government successfully rejected the governor's proposed land allocation, by arguing that the area allocated had long been used and managed by the community. The community on the allocated land had also voiced their opposition to the plantation investment. The sub-district head explained that the local government had indirectly used the 'voice of the people' as its power to enforce authority over the district. Because the district head issues the location licence, he or she can also revoke it if there is sufficient reason to do so. However, revoking the license does not automatically free up the land for reallocation. For example, the district head revoked the location licence of the plantation company PT. Alam Kendawangan Indah because there were no activities underway in the field. However, the company still had an investment licence for the land; and, as the authority to revoke this is in the hands of the Director General of Plantations; the status of the plantation land became unclear and the district head could not reallocate it.

These examples illustrate the perception held by a number of officials in the Ketapang local government interviewed for this research, who view the investment licensing procedure as overly complex and inefficient; and who have proposed a transfer of the whole licensing process to the district level. This, they assert would both encourage more investment and avoid the problems which arise due to the lack of clarity over provincial and district-level authority over licence allocation.

\subsubsection{Oil palm versus rubber}

For more than two decades, the rubber industry has been experiencing a recession. One reason is that there has been relatively little investment in rejuvenating old plants whose productivity has started to decline. This recession is marked by the number of crumb rubber industries in West Kalimantan declining from 13 to 6 in year 2000 . Almost half the existing industries were forced to close down because of a shortage of raw materials.

The introduction of oil palm through the Transmigration-PIR system changed the map of plantation crops in Ketapang. Oil palm plantations were pioneered and developed in the south of the district. As outlined in section 3.2.1.3 (Local community resistance), initial community 
resistance to oil palm plantations was overcome once the Transmigration-PIR scheme started to show real profits. Dayak communities in the north, however, generally rejected the oil palm plantations (Table 10). Thus in Ketapang district, the preferred plantation crop in the south (south of the River Pawan) is oil palm, while the north tends to reject oil palm in favour of rubber.

The north's rejection of oil palm is supported by the Institute of Dayakology, a Pontianak-based NGO formed by indigenous people. This NGO appears to have succeeded in spreading the message that, based on past experience, modern plantations are detrimental to the local communities and that rubber cultivation is more profitable and appropriate to the Dayak culture (Florus and Petebang 1999).

\subsubsection{Plantations as a source of local revenues}

Plantations have so far provided very little in the way of local revenues (PAD) for the Ketapang district because local government does not have authority over these activities. The District Plantations Branch Office is an agency of the provincial level office. However, a DPRD member interviewed for this research claimed that some district administrations were already charging Rp 5 per Fresh Fruit Bunch (FFB). Other potential sources of PAD from the plantations subsector are levies on product processing units (CPO factories), Land and Building Tax (PBB), which is not yet optimal, and seed quality inspection and supervision fees. It would also be possible to impose levies on a number of types of licensing related to private investment in the plantations sector.

The Ketapang DPRD has begun to consider the option of a drafting a regional regulation that gives district government the authority to raise local revenue from the plantations subsector. It was expected that this source could be an important contributor to PAD in the future, as a substantial area of land had already been or was allocated for agro-industrial oil and rubber plantation development. With respect to regional autonomy, the officials at the regional Plantations Office interviewed for this study asserted that that it would be better for Ketapang district to focus attention on developing plantations (both oil palm and rubber) rather than on exploiting forest resources. However, ensuring that the role of agroindustrial plantation sector as significant source of PAD, would require the local government to either attract investors into the area or to allocate a significant proportion of their budget to investment in developing this subsector. To date, the Ketapang Regional Budget allocation for the plantations sector remains very small. In 1999/ 2000, it was only Rp 180 million, comprising funds for the People's Plantation Development Project (Rp 130 million) and the People's Plantation Production Growth Project (Rp 50 million).

\subsection{MANAGEMENT OF THE GUNUNG PALUNG NATIONAL PARK}

In the Ketapang district, the management of the Gunung Palung National Park is a good illustration of where conflicts of interest have occurred over the utilisation of a protected area and the natural resources within it.

\subsubsection{Gunung Palung National Park}

Gunung Palung National Park (TNGP) is one of four national parks in West Kalimantan. It was established in $1937^{44}$ as a forest nature reserve covering 30,000 ha. In 1981 its status was raised to that of a wildlife reserve and the area was increased to 90,000 ha. ${ }^{45}$ The status of national park was conferred on 24 March $1990 .{ }^{46}$

The topography of the TNGP consists mainly of low plains with a few mountains; the highest peak is Gunung Palung (1,116 m asl). Based on the latest map issued by the Ministry of Forestry in 2000 (see attachment), the surrounding areas contain permanent and limited production forest, and conversion forest. An area of about 8,000 ha in the north functions as a permanent production forest (the proposed location for the Harvard (Community Forest) under Community Forestry Concession (HPHKM), which is located within the park. A sealed main road runs through the east of the TNGP, linking Ketapang to Teluk Melano. There are a number of settlements along the road.

The TNGP is a globally significant site, in terms of bio-diversity conservation. The region contains seven types of tropical rainforest ecosystem: sub- 
alpine rain forest, montane rain forest, lowland rain forest, alluvial forest, moss forest, swamp forest, mangrove forest and rheofite vegetation formations that grow along river banks. This comprehensive range of vegetation is home to a wide range of fauna; it is also the endemic habitat of the orangutan (Pongo pygmaeus), with the highest population density in Kalimantan (four individuals per $\mathrm{km}^{2}$ (UPT-TNGP 2000).

The TNGP area is divided into five subdistricts (Matan Hilir Utara, Sukadana, Simpang Hilir, Sei Laur and Ng Tayap). Most people living in and around the park are farmers, some of whom practice swidden agriculture. Based on a survey carried out by the park management (1996), the community has a good understanding of the term 'conservation area' and is well aware that the TNGP has this status, although a number do carry out timber harvesting activities.

\subsubsection{Management and activities in the TNGP area}

A national park is a nature preservation area with an original or unique ecosystem, managed through zoning for research, science, education and cultural, tourism and recreational activities. ${ }^{47}$ As with other national parks, the authority over, and responsibility for managing TNGP lies with the central government through the TNGP Technical Executive Unit (UPT), which is directly accountable to the Directorate General of Nature Protection and Conservation at the Ministry of Forestry. ${ }^{48}$

TNGP is managed by zones based on site plan documents: they comprise the core, forest, research use, tourism use, traditional and rehabilitation zones. The main aim of the park is the conservation of this wet, tropical rainforest ecosystem, the preservation of its natural resources; and to ensure its protection as a habitat for wildlife in the interest of research, science, education, ecotourism and sustainable use by the communities living in the area. At the time this research was conducted, allowable activities in the buffer zones, which are outside but closely related to the management zones, had yet to be stipulated and delineated by the local government. ${ }^{49}$ The local communities living in the area carry out a number of activities within the park boundaries including exploiting timber and NTFPs, cultivation and mining $\mathrm{C}$-classified extractives. This area attracts international interest as a site for research. TNGP UPT's records show that from 1987 to March 2000, there had been 98 researchers working in the area of whom 47of whom were foreigners. The most well known research activities have been conducted by Harvard University, which has had researchers exploring the wealth of biodiversity in this area for about 15 years. Research activities are still being carried out by the LTFE, based in a research station at Gunung Panti.

\subsubsection{Responses to the TNGP management activities}

Until 1996, TNGP was still classified as a nature reserve, and few difficulties were recorded (KSDA Unit records). Mackinnon (1990) even used Gunung Palung as an example of a protected area supported by the local adat laws and traditions, which were also respected by incomers to the area. There was minimal disturbance, and the management of the area was sustainable (conservation rangers were not considered necessary). This is no longer the case. The TNGP area has come under significant pressure, particularly from logging activities. An official from Provincial Bappeda claimed that TNGP was under greater threat than any other national park in the province. Increased demand for timber, which has not been met by production forest (HPH) areas, has meant that the park has become an alternative source of timber. Individuals interviewed for this research indicated that adat regulations and traditions were no longer being observed and the security system put in place by the TNGP UPT was not sufficient. Open accesses from all sides, by both land and river, and the activities of some members of the local community, who are involved in commercial timber exploitation have all served to exacerbate the situation. It is estimated that a third of the households in and around TNGP derived a significant proportion of their income from timber exploitation.

At the field level, there is a need to increase local awareness of conservation issues within the park. Local communities also need to be able to use forest resources, particularly timber, as a source of income. Amongst those interviewed for this research there were widespread indications that the centralised management system, does not take 
local community interests and needs into account. This in part, was identified as a cause of the failure of the current conservation system. In other words, whilst the centralised control of the park has been claiming successful conservation; it has depended on, what some saw as a repressive approach, which carries high social costs, and has failed to secure real benefits for the local communities living in and around TNGP. This is supported by Mackinnon (1990), who states that one criterion for a national park is that it should provide clear benefits for local communities within the region.

At present, the authority for the management of protected areas, including national parks, is held by the central government. There are no plans to transfer this authority under the implementation of regional autonomy. The central government's perceived ability to maximise the real benefits of TNGP, together with the increasing pressure on its natural resources are causing a number of stakeholders to consider applying for independent, local management of the area. At Kutai National Park (East Kalimantan), the local government declared itself capable of independently managing the area; and this was approved by the UPT through the head of the park informing the Director General of Nature Protection and Conservation. ${ }^{50}$

\subsubsection{TNGP Technical Executive Unit}

A UPT, directly accountable to the Directorate General of Nature Protection and Conservation, was set up in 1997. ${ }^{51}$ Whilst this was a positive step, those interviewed for this research claimed that it was not yet supported by the needed infrastructure, apparatus and funding resources.

In order to safeguard the 90,000 ha of TNGP, the UPT is supported by 31 forest police in four regional units (Pangkal Tapang, Sukadana, Batu Barat and Kubing), which operate along the borders of the park. No other infrastructure as set out in the site plan has been put in place.

Although the UPT represents the central government and is fully authorised in management matters, several matters remain at the discretion of other government bodies and individuals. The UPT has no control over licensing research, particularly that initiated by LIPI (The Indonesian Institute of Science), and only receives a copy of the licence once it has been issued. Research findings are also retained at the central level. Thus the park management has been unable to fully benefit from Harvard University's 15 years of research; the UPT has few copies of the results and, furthermore, officials interviewed for this research did not know how to acquire them.

There is also limited capacity to carry out outreach activities with the local communities. Harvard established 35 Community Self-Help Groups (KSM) in the region and, with support, these groups got as far as submitting a model for the empowerment of the community economy through Community Forestry Concessions (HPHKM). The TNGP UPT felt that the proposed HPHKMs could actually become buffer zones for the national park if there were clear regulations, and these were implemented consistently. However, they could also pose a threat to the preservation of forest resources because of limited capacity within the KSM, resistance from those communities not included in the Harvard scheme and, more importantly, the fact that the status of the regions and the management plans for the buffer zones are not yet clear.

With all these limitations, TNGP UPT officials think it is necessary to involve other stakeholders in the park's management. At present, other parties, such as the local government, security forces and adat communities, have limited involvement, particularly in cases involving conflicts with the community groups. In the future, it will be necessary to accommodate a wider range of stakeholders in the park's management. This would include developing a greater role for the district government. The current regulations do not define any role for the district government in the management of the area within the national park. The district government, is, however responsible for the management of buffer zone outside the park. The head of TNGP indicated that an overhaul of the legal foundations governing the management of the park was required. He also felt that, given the current condition of the park, any transfer of responsibility for its management could be more of a financial burden than a source of revenue for the district government. One Bappeda official, in contrast, claimed that an expanded district government role would provide greater opportunities to increase local revenues (PAD), for 
example through transferring control of tourism in the park.

\subsubsection{Local government and the DPRD}

Since it was declared a national park, Gunung Palung has not demonstrated clear socio-economic benefits for local communities living in and around the park. In fact, it's status as a national park has been the source of a number of controversies. Based on the regulations in force at the time this research was conducted, sources of real income from the park were to be generated by tourism activities, distributed $30 \%$ to the centre, $30 \%$ to the province and $40 \%$ to the district. As the UPT's activities are limited, particularly in the management of tourism, the district government had demanded an increased role. Available records recorded just 134 visitors to TNGP in 1999 compared to as many as 66,000 visitors to the Gede Pangrango National Park in Java (MTGPNP 1996). These statistics demonstrate that there was potential for TNGP to be further developed as an ecotourism attraction, which could, in turn provide a good source of revenue for the local communities and for the district government.

Another potential source of income is the traditional exploitation of rubber plantations and NTFPs such as durian fruit, in addition to opportunities for local people to carry out cultivation activities within the national park. A member of the DPRD interviewed for this research indicated that there was room for more co-ordination of commercial opportunities by Bappeda, as a means of securing income for local communities and thereby improving the environmental sustainability of the park itself. As a regional and a national asset, it is important that the TNGP is managed sustainably in the interests of the local communities and the conservation of the park. ${ }^{52}$

The local government has looked carefully at Harvard University's activities, focusing particularly on the idea of recommending allocating Community Forestry Concessions (HPHKM) to the Self-help Community Groups KSMs in buffer zones. This issue has now become a topic for public debate following the burning of the Lubuk Kuali camp (see section 4.3.3.3.). This discussion has attracted attention at the international level as it concerns the activities of supporting international institutions, such as the Biological Conservation Network. It can be argued that improved communication with all of the stakeholders, including the local government, may help to avoid some of these problems in the future. District government officials interviewed for this research claimed that, despite the fact that the district government is responsible for managing the buffer zone, it has been excluded from decision-making processes related to the park itself. For example the agreement over Community Forestry Concessions (HPHKM) was made at the central level (Harvard's MoU was with the Director General of Forest Protection, Ministry of Forestry). At the time this research was conducted, Harvard had become involved in discussions with the local government to try to resolve some of these difficulties, but in the meantime the HPHKM project had had to be delayed. One DPRD member asserted that the whole project should be revised, and that Community Forestry Concessions should not be granted within TNGP. This position has since been supported by the provincial government, which enforced a status quo on all activities in the TNGP (Pontianak Post 26.07.00).

\subsubsection{Harvard University and the NGOs}

In 1994, some researcher from Harvard University developed a concept of 'production forest' management (outside TNGP area) by local communities. In relation to the Hutan Kemasyarakatan (Community Forest or HKM) project (discussed above in section 3.2.1.4, Horizontal Conflicts within the Local Community), the Director of Harvard University LTFE said in a discussion forum that the goal of these activities was to find solutions leading to sustainable timber production and the conservation of the biodiversity in logged-over areas, particularly in the buffer zones on TNGP's borders. It was also hoped that this model would produce an incentive for the local communities to protect the park's natural resources. The second goal was to assist in increasing the capacity of the local government and NGOs to apply community-based forest management (CBFM) in other places and to integrate economic development with biodiversity conservation through production forest management. The final aim was the establishment of an institution for entrepreneurs from the community, dealing with forest management in ex- 
HPH areas, low-impact logging, wood processing in the form of sawn timber (seen as more profitable than selling $\log$ ) and developing a marketing system, including seeking ecolabeling certification for the products.

Here, the aim was to empower local communities to manage forests in collaboration with timber processing businesses. When they were interviewed for this research the heads of the local subdistricts, Sukadana and Simpang Hilir, both had a negative view of the Harvard HKM controversy. They saw the initiative as having caused unrest in their administrative areas. While the project may have been operating in the area for 15 years, the subdistrict heads knew little about its current and future activities.

They argued that the project had actually served to divide the people into two groups, which they classified as participants (the minority) and observers (the majority). Resentment had developed towards the participants, as they appear to be an exclusive group. Local and provincial NGOs have become increasingly critical of the management of TNGP a number of NGOs have held discussion forums on TNGP for stakeholders, with the backing of foreign donors. USAID's Natural Resources Management Project is also currently running a programme to develop the institutional strength of several new NGOs. These developments have been positively received by those involved, including local government, as they hope it will also contribute to a solution to conflicts in the area. A central concern for NGOs and international institutions working in the area is to find methods of integrating conservation objectives with socio-economic needs of the communities living in and near the park. This is considered to be an important issue to take into account to prevent new controversies arising.

\subsubsection{Communities in and around Gunung Palung National Park}

With the official declaration of TNGP as a protected area, the community's access to its resources has been replaced by what is called a 'conservation benefit'. At the time this study was conducted, economic hardship had led to increased demands for local community access to forest products. Given the present condition of the park, and the relative underdevelopment of eco-tourism opportunities, the advantages of conserving the forest in the park are not clear to the local community members. One $\mathrm{NGO}$ based in Pontianak observed that pressure on the park's natural resource, particularly in relation to timber extraction is increasing. This is reflected by the increasing number of people becoming involved in logging within the park.

Feedback from interviews with stakeholders suggests that one way to halt this exploitation of the forest, particularly within the TNGP, is to have an alternative source of income that is more attractive to the community. Other potential benefits of conservation must therefore be realised, for example, ecotourism, which could open up a new employment opportunities and increase regional revenues from taxes and levies. The same applies to research activities, which could also be a source of revenue.

The main difficulty is how efforts to protect conservation areas can balance competing demands for ecological and economic benefits. Any efforts must be supported by legal actions that are clear and authoritative in the eyes of the local communities, who feel they have not been treated fairly in the past. ${ }^{53}$ The behaviour of the government agencies reportedly involved in logging must also be brought under control (Silva Indonesia Pontianak, Harian Equator, 25 June 1999). The Ketapang DPRD itself is attempting to address some of problems associated by the pressure on the natural resources in TNGP by preparing a regional regulation regarding the management of logging and the control of cultivation activities and C-classified extractives in the area. This regulation will relate to the local government's authority to manage the buffer zones, which basically involves controlling natural resource exploitation in the area in a way that limits incursions into Gunung Palung National Park's core area. 
Conflicts of interests, diverse in both horizontal and vertical ways, have pervaded across the decentralized forestry and plantation sectors in Ketapang district, and West Kalimantan in general. The local governments and communities risk losing out on the opportunities and benefits of good governance, which calls for proper devolution of authorities as an urgent priority. The previous analysis at the provincial and district level as well as the thematic cases (adat communities, plantations and National Parks) showed indicators of decentralisation on decision making and administration/management of the forestry/ plantation sector, which is summarised as follows:

\subsection{DE FACTO DECENTRALISATION}

Regional autonomy represents an opportunity for regional governments, at both provincial and district levels, to develop policies, and take administrative measures related to forestry and plantations beyond the centralistic guidelines (laws and regulations) of the Ministry of Forestry and Estate Crops. This is illustrated by the formal (government policies) and informal (nongovernment policy) de facto measures adopted.

\subsubsection{Illegal logging}

The district government is aware that a significant proportion of government revenue is lost through illegal logging. It also realises that it is not possible to stop these activities because of the wide range of stakeholders (who benefit from these activities) and local resistance to forest management policies that do not benefit the local economy. As in other areas in Indonesia, in West Kalimantan the escalation of illegal logging would seem to have been more related to the economic crisis and 'reformasi' euphoria than the structured and proper devolution of governing authorities. Whilst Illegal logging does not make any direct or official contributions to PAD, benefits are accrued indirectly through the associated multiplier effects in the transportation services (land and inland waterways/sea), hotel, wholesale trade and smallscale timber processing sectors. The latter industry contributes to the local economy both through contributions to the GRDP and by providing localemployment. Because of these indirect benefits, the district government has tended to turn a blind eye to illegal logging activities. Moreover, some officials interviewed for this research were concerned that the economic benefits that could be directly derived by the local government did not compare favourably with the costs of eradicating these activities. The Ketapang district government's response to decentralisation was to draw up regulations aimed at increasing its share of the revenue derived from logging activities, and to replace informal revenues (generated by illegal logging) with legal levies and fees.

\subsubsection{Harvest Concession for Forest Products (HPHH)}

Within the Ministry of Forestry and Estate Crop's decree, authorization is given for a shift in the administrative authority to the provincial and district level to grant small-scale timber extraction permits in an effort to 'legalize' the transportation of illegally harvested timber. The timber's origin is not in question. The district government is 'laundering' the status of illegal logs, which are 
referred to as 'local community produce'. The decree gives the impression that the central government is committed to democratic economic development. Pursuant to that decree, the Regional Regulation on HPHH gives more opportunities to local communities to manage Production Forest. The HPHH has been seen as an opportunity to restore traditional community rights to the forest, as well as being a potential source of regional revenue (PAD). In practice, local people do not have the capital nor equipment to operate the HPHH area and they cooperate with timber companies holding HPH concessions under a 'profit-sharing' arrangement. In reality the utilisation of forest resources is centred around a few established companies. This benefits the government by having less concession holders to control.

\subsubsection{Plantation investment procedures}

The five plantation investment systems, that require the participation of cooperatives as shareholders, were seen to be impeding the process of investment in the plantations sector. This was caused by the difficulties in ensuring equal partnerships and benefit sharing between local communities and private sector investors.

\subsubsection{Local community autonomy}

The perception of most local communities is that the private forestry sector and agro-industrial plantation companies limit their access to forestland and resources, thereby causing them a financial loss. The district government, however, wants to increase investment to stimulate the region's economic growth, and to generate much needed district revenue. In some areas, this has led to a conflict of interest between the district government and local communities. An exception was in Ketapang, where the local government shared the concerns of the local community because the investors' proposals did not conform to its desire to limit the expansion of oil palm plantations. These were seen as detrimental from an ecological perspective. In cases such as this, the local government cites 'local community autonomy' as justification for its decisions and actions. A participatory map clarifying adat tenurial rights must be developed as a tool that helps further justification of the local community autonomy.

\subsection{LINKING DECENTRALISATION AND FOREST CONSERVATION}

Despite the fact that forest exploitation e.g. illegal logging, in the sense of people's resistance, has been viewed as a form of de facto or informal decentralisation, the decentralisation itself does not necessarily mean that forest resources will be threatened by an uncontrolled increase in forest destruction. It has also the potential to bring about positive results for forest conservation. Although it can be anticipated that the immediate action of the district government will be aimed at making the forests the primary source of PAD, this does not automatically mean that forest exploitation will increase. Boosting revenues from the forestry sector does not have to be achieved by increasing wood production, but could also be met by raising taxes and levies on a wide range of current (legal and illegal) timber extraction, transportation and processing activities. After all, decentralisation is only as good as the governance practices it emanates from.

\subsection{EMPOWERMENT OF LOCAL PEOPLE}

At the local level decentralisation tends to be interpreted as empowering the regional government through the transfer of authority from the central government. The pattern may be viewed as shifting the 'centralisation', from the national to the district level. Whilst this interpretation involves a power struggle between the provincial and district governments, where each party tries to secure the greatest portion of the decentralised authority; there was little or no consideration of how decentralisation processes could lead to the empowerment of local communities. NGO representatives interviewed for this research, most of whom were based in Pontianak, held that local communities must be empowered through the process of regional autonomy, and that they receive an equitable share of the socio-economic opportunities offered by decentralisation. Having accepted that to be effective decentralisation should orient towards the lowest common denominator namely 'local people', legal provision should be taken into account as well. No matter how tattered the state's law has been, the legal 
framework should be factored in policy deliberations. We could find a better, legal bases of 'empowerment' as well as practical ways to it, e.g., the strengthening of 'adat' claims over forest land, including the use of participatory mapping (by the local communities) as a counterbalance to the formal maps used by the government when planning resource management. Eventually the alliance forged between district government and community leaders (DAD or Dayak Adat Council) should be viewed as a measure of empowerment (namely pro-community) for which progress needs to be monitored.

\subsection{THE ROLE OF THE PRIVATE SECTOR}

Decentralisation processes do offer increased opportunities for district governments to regulate and raise revenue from the forestry and agroindustrial private sector. Nevertheless, the district has yet to develop the local economy to provide the level of investment required to ensure successful development of the sector in the longterm. Thus, the district government is likely to continue to rely on the private sector for investment. This dependence on private sector investment may result in the private sector interests predominating forestry and agro-industrial decision-making. For example, land allocations by the governor for plantation sector development has exceeded the amount of land available for this purpose in Ketapang. The introduction by the district government of a regional regulation that effectively 'legalises' timber harvested without a permit can also be seen in this light. However, the district does have the authority to revoke a location licence if the investor does not undertake activities in the field. Decentralisation may direct district government policy towards providing greater incentives to companies, which could produce real and sizeable revenues for the government. This could also have a significant effect on the development of the local economy.

\subsection{LAND USE PLANNING}

In the context of decentralisation, land use planning is an area where in which a complex set of competing interests converges. These conflicts over authority over land use planning often occur between the provincial Bappeda and the Forestry Office (Dinas Kehutanan) on one level and between the provincial and district governments on another. The conflict between the provincial Bappeda and the Ministry of Forestry over the construction of the "harmonised map' represents the struggle for authority over land areas between the region and the centre. The Bappeda wanted to change the status of deforested areas so that they could be used for regional development, whereas MoFEC rejected this proposed change of status, which would reduce the area of land under its administrative authority. The case of the Ketapang district government's conflict with the provincial government over the granting of plantation concessions, illustrates the type of conflict arising between the provincial and district governments.

\subsection{FINANCING LOCAL DEVELOPMENT}

The official revenues derived by regional governments (at the provincial and district level) from forestry activities, are very limited compared to the value they represent to the central government and the private sector. Therefore, decentralisation represents an opportunity for regional governments, particularly at district level, to increase local revenues to finance local economic development. This is reflected by the proposed concept of a 'district forest' (a forest area under the authority of the district), for the forestry and plantations sector, and the transfer of forest utilisation licensing from the centre to the region. This latter action is also intended to help prevent overlaps between HPH areas (the centre's authority over licensing), HPHH areas (the district's authority over licensing) and community forest based on adat claims. The results of a participatory mapping activity by the local people (with assistance from an NGO) clearly show these overlaps.

\subsection{HUMAN RESOURCES FOR DECENTRALISATION}

The transfer of forestry matters to the district government level is not stated explicitly in Regional Regulation No. 25/2000, leaving opportunity for a tug-of-war in the process of decentralising forestry affairs. The agencies of the Ministry of Forestry and 
Estate Crops, The Regional Forestry and Estate Crops Office (Kanwil), and the Provincial Forestry Office (Dinas Kehutanan) officials interviewed for this research, cited limited professional capacity at the district level as a reason for deferring any real transfer of authority over forestry and agro-industrial plantation activities. Instead, these agencies recommend that decentralisation be carried out in stages, to allow time for the district government's ability to manage forest resources to develop. The Provincial Forestry Office official refused the idea of making a District Forestry Office instead they proposed the establishment of a UPT Forestry at the sub district level. Such a scheme (decentralisation to sub-district rather than district level) has yet to form a good legal base. As a consequence, the district government will have less or no authority in the district forestry sector. However, the district government favours the immediate transfer of authority over the forest management sector, to the district level. If the local agencies felt unable to implement management effectively, they would be entitled by law to return control temporarily to the provincial level. To this end, the Ketapang government is thinking of replacing the KPH Office with an Agriculture and Forestry Office, so that neither the Ministry of Forestry nor the Provincial Forestry Office would have an 'extension' in the district. They have also considered transforming the UPT of TNGP (an agent of the Ministry of Forestry) into a regional UPT.

\subsection{NON-FOREST RESOURCES (MINING)}

The decentralisation of authority over the management of non-forest resources may result in the exploitation of forest resources declining as a source of PAD for the district. One of the nonforest resources that could potentially substitute forest resources, to provide revenue for the region, is mining. It is assumed that gold and sand mining in Ketapang District would give significant economic contributions to the region if the district government were authorised to manage their mining resources. In this case, the district government would not have to use forest resources as a source of PAD, instead the regional revenues would have been provided by the mining sector.

\subsection{PROTECTED AREAS}

Protected forest zones constitute areas where ecological interests (under the Ministry of Forestry and Estate Crops) are frequently in conflict with economic interests (under the regional government, local entrepreneurs and local communities). The case of TNGP indicates that the very small economic benefit derived by the regional government and the local communities may, in part, have contributed to the escalation of illegal logging in the area. A system of management and incentive, which automatically involves the district government and the local communities, is required. This is to ensure that the park's management meets the needs and interests of the local community. The utilisation areas (Kawasan Pemanfaatan) and non-timber forest resources of TNGP could potentially provide the local government and communities with economic benefits such as ecotourism. Based on Article 10 paragraph 1 of Law No. 22/1999, the district government hoped to manage the ecotourism potential of the national park, to increase the park's contributions to the local economy. 


\section{ENDNOTES}

1. Decree of the Minister of Agriculture Number 680/Kpts/Um/8/1981 regarding Guidelines for Forest Land Use by Consensus.

2. The total area for HPH was $7,136,000$ ha, while the total protected area, according to the RTRWP, was 3,812,740 ha.

3. Regional Regulation of the Province of West Kalimantan No. 1/1995.

4. Decree No. 143/1995.

5. Decree No. 316/1999.

6. Regional Regulation No. 4/1999.

7. Under the APBD, local revenues are obtained from regional taxes, local levies, profits from regionally owned enterprises and other items.

8. Bappeda, in cooperation with consultants, completed the Ketapang RTRWK in 1998 based on field data.

9. Swatantra is the term applied to a government region during the $1950 \mathrm{~s}$, and is now equivalent to a province.

10. Government Regulation No. 21/1970 regarding Forest Utilisation through HPH and HPHH.

11. Pursuant to Decree of the Regional Affairs Board (DPD) of the Level I Swatantra of West Kalimantan No. 8/DPD-1959.

12. Decree of the Governor of West Kalimantan No. 331/1986.

13. The UPTs came under the control of the Regional Office with the Decision of the Minister of Forestry No. 144-147/Kpts-II/1991.

14. Danau Sentarum National Park was declared as such pursuant to Decree of the Minister of Forestry and Estate Crops No. 34/Kpts-II/1999, but remains under the management of the KSDA Unit.

15. Decree of Minister of Forestry No. 185/ Kpts-II/1997 about functions and structures of National Park and its Technical Executive Unit

16. Decree of Minister of Forestry No.05.1/ $\mathrm{Kpps} / \mathrm{II} / 2000$ about transfer authority to issue HPH timber concessions for areas up to 10,000 ha and Timber Clearance Permit for areas up to 100 ha to the regional government

17. Decree of the Governor of West Kalimantan No. 389/2000.

18. Decree of the Minister of Forestry and Estate Crops No.107/1999.

19. This followed the issue of Law No. 5/1967 regarding Forestry, Law No. 1/1967 regarding Foreign Direct Investment, Law No. 6/1968 regarding Domestic Investment and Government Regulation No. 21/1970 regarding Forest Utilisation through HPH and HPHH.

20. Decree of the Minister of Agriculture No. Kep 79/11-1967.

21. Forestry Work Programmes (BKPH) are the permanent annual work plans for former HPHs now managed by state-owned enterprises. It is equivalent to an Annual Management Plan for a regular $\mathrm{HPH}$.

22. The province supplying the greatest amount of wood to West Kalimantan in 1999/2000 was Central Kalimantan $\left(860,059 \mathrm{~m}^{3}\right)$, followed by East Kalimantan $\left(375,3739 \mathrm{~m}^{3}\right)$. Other provinces supplied less than $100,000 \mathrm{~m}^{3}$.

23. Government Regulation No. 7/1990.

24. Kelapa dalam is a plantation term for a local palm of a different type to hybrid palms.

25. Memorandum of the Governor of West Kalimantan 1983-1988.

26. Decree of the Minister of Forestry and Estate Crops No. 107/1999.

27. The patungan (joint venture) system is operated by a private investor with a DR loan facility from government equity financing through a BUMN (state-owned enterprise); the murni (pure) system uses only private capital.

28. The KPH Office's assessment is that production from community logging totalled $150,000 \mathrm{~m}^{3}$ and approximately $300,000 \mathrm{~m}^{3}$ of sawn timber was produced per year by hundreds of 
'illegal' sawmills from $600,000 \mathrm{~m}^{3}$ of logs.

29. Approved tax sources include hotels and restaurants, entertainment, advertising, street lighting, C-classified extractives and groundwater.

30. Approved levies include market levies, uang sempadan on construction permits, set transportation route levies, uang pangkalan levies, levies on livestock inspection fees, levies on the leasing of land or property, bus station and taxi levies, hospital and clinic levies, the lease of regional government-owned equipment, levies on resident's identification cards, parking lots and public cleaning.

31. Decree of the Minister of Forestry and Estate Crops No. 107/1999.

32. The delegated authority includes reforestation/conservation, management of community/protected forests, and the management of non-timber forest products including those in forest concession zones.

33. Stipulated on 18 October 2000 and enacted on 1 November 2000. This Regional Regulation essentially regulates the implementation of forest management in the form of HPHH, timber exploitation licenses, forest product management, disbursement of forest product fees (IHH), procedures for the receipt and use of $\mathrm{IHH}$, procedures for filing applications for forest management licenses, the stipulation of forest areas in Ketapang district and timber trade procedures. The implementation of each of these matters will be regulated in a Decree of the District Head, which is currently pending approval from the Regional Legislative Assembly (DPRD) (March 2001).

34. Based on Law No. $25 / 1999$, districts are entitled to $64 \%$ of IHPH/IHPHH, $32 \%$ of PSDH and $40 \%$ of DR.

35. The amount will be stipulated through a Decision of the District Head.

36. Regulations that accommodate recognition of adat communities, ulayat land rights and adat laws can be found in Act No.5/1960 article 2,3 and 5) on the Basic Agrarian Law and Act No.41/ 1999 article 37 on Basic Forestry Law

37. Estimates from a member of staff at the Economics Division of the Ketapang local government.

38. Law No. 22/1999 on Regional Governance.
39. Based on a Singaporean entrepreneur's investigations.

40. This regulation replaces Regional Regulation No. 21/1970, in conjunction with Regional Regulation No. 18/1975 regarding HPH and $\mathrm{HPHH}$.

41. Until then, the utilisation of forest products, particularly wood, had been granted only to large-scale entrepreneurs through HPHs despite the fact that Regional Regulation No. 21/1970 explicitly regulates HPHHs.

42. This new HPH was stipulated by Decree of the Minister of Forestry and Estate Crops No. 938/Kpts-VI/1999 dated October 14, 1999; Letter of Recommendation of the Governor of West Kalimantan No. 650/3425-A/18 dated 10-10-1999 in the ex-HPH area of PT. Djuaja II Sandai.

43. Decree of the Minister of Forestry and Estate Crops No. 107/1999.

44. Pursuant to Staatsblad No. 4/13.ZB/1937.

45. Based on Decree of the Minister of Agriculture No. 1014/Kpts/UM/12/1981.

46. Based on Decree of the Ministry of Forestry No. 448/Kpts-II/90.

47. As defined in article 1 paragraph 14 of Law No. 5/1990 regarding natural resource conservation and ecosystems.

48. Decree of the Minister of Forestry No. 185/Kpts-II/1997.

49. Circular Letter of the Minister of Home Affairs No. 660.1/269/V/Bangda dated 16 February 1999.

50. Letter No. 984/BTNK-2/2000 to the Director General of Nature Protection and Conservation regarding the transfer of the management of the Kutai National Park to the local government.

51. Decree of the Minister of Forestry No. 185/Kpts-II/1997.

52. In accordance with article 10 paragraph 1 of Law No. 22/1999.

53. The people of the Laman Satong Village, who live in the TNGP area, explained to the Ketapang DAD 'that the efforts to protect the TNGP that have been made up to now will be meaningless; if there is an invasion of loggers from outside the area nothing can be done as they have no legal authority to do anything. 


\section{REFERENCES}

Bappeda-BPS Propinsi Kalimantan Barat 1999. Kalimantan Barat Dalam Angka 1998.

Bappeda-BPS Propinsi Kalimantan Barat 1999. Pendapatan Regional Kalimantan Barat 1993 - 1998. Pontianak, Kalbar, Indonesia.

Bappeda Kabupaten Dati II Ketapang 1994. Buku Data Pokok Pembanguan Kabupaten Dati II Ketapang 1993: Updating data. Bappeda Ketapang, Kalbar, Indonesia.

Bappeda Kabupaten Dati II Ketapang 1996. Data Pokok Pembangunan Daerah. Ketapang, Kalbar, Indonesia.

Bappeda Kabupaten Dati II Ketapang 1998. Rencana Tata Ruang Wilayah Kabupaten Daerah Tingkat II Ketapang tahun 2009 Buku II. Ketapang, Kalbar, Indonesia.

Bappeda Kabupaten Dati II Ketapang 1999. Profil Daerah Kabupaten Daerah Tingkat II Ketapang 1998. Ketapang, Kalbar, Indonesia.

Bappeda Kabupaten Dati II Ketapang 1999. Buku Data Pokok Pembanguan Kabupaten Dati II Ketapang 1998 : Updating data. Bappeda Ketapang, Kalbar, Indonesia.

Bappeda Kabupaten Ketapang 2000. Proposal Program Pengembangan Wilayah Terpadu tahun 2000 - 2004 . Pemerintah Kabupaten Ketapang, Kalbar, Indonesia.

BKPMD Propinsi Kalbar 2000. Perkembangan Penanaman Modal dalam rangka Penanaman Modal Dalam Negeri dan Penanaman Modal Asing di Kalimantan Barat 31 Desember 1999. Badan Koordinasi Penanaman Modal Daerah Propinsi Kalbar, Pontianak, Kalbar, Indonesia.

BPS Kabupaten Ketapang 1999. Kabupaten Ketapang Dalam Angka 1998. Badan Pusat Statistik Kabupaten Ketapang, Kalbar, Indonesia.

BPS Kabupaten Ketapang 1999. Pendapatan Regional Kabupaten Ketapang 1994-1998.
Badan Pusat Statistik Kabupaten Ketapang, Kalbar, Indonesia.

BPS Propinsi Kalimantan Barat 1998. Profil Kalimantan Barat 1996/1997. Kantor Statistik Propinsi Kalimantan Barat. Pontianak, Kalbar, Indonesia.

BPS Propinsi Kalimantan Barat 1997. Statistik Sumberdaya Alam Kalimantan Barat 1996. Kantor Statistik Propinsi Kalimantan Barat. Pontianak, Kalbar, Indonesia.

BPS Propinsi Kalimantan Barat 1999. Statistik Industri Besar Sedang Kalimantan Barat 19971998. Badan Pusat Statistik Propinsi Kalimantan Barat. Pontianak, Kalbar, Indonesia.

Cabang Dinas Perkebunan Kabupaten Ketapang 1994. Memori Kepala Cabang Dinas Perkebunan Propinsi Dati I Kalbar di Ketapang. Ketapang, Kalbar Indonesia.

Cabang Dinas Perkebunan Kabupaten Ketapang. April 1999. Laporan Tahunan Cabang Dinas Perkebunan Kabupaten Ketapang 1998/1999.

Cabang Dinas Perkebunan Kabupaten Ketapang. April 1998. Laporan Tahunan Cabang Dinas Perkebunan Kabupaten Ketapang 1997/1998. Pontianak, Kalbar, Indonesia.

Cabang Dinas Perkebunan Ketapang 2000. Pembangunan Sub Sektor Perkebunan di Kabupaten Ketapang Sampai April tahun 2000. Ketapang, Kalbar, Indonesia.

Dinas Kehutanan Propinsi Kalimantan Barat 1997. Statistik Kehutanan Kalimantan Barat 1992/1993-1996/1997. Pontianak, Kalbar, Indonesia.

Dinas Kehutanan Propinsi Kalimantan Barat 1999. Statistik Kehutanan Kalimantan Barat 1994/1995-1998/1999. Pontianak, Kalbar, Indonesia.

Dinas Kehutanan Propinsi Kalimantan Barat 1999. 
Laporan Tahunan Dinas Kehutanan Propinsi Dati I Kalimantan Barat 1998/1999. Pontianak, Kalbar, Indonesia.

Dinas Kehutanan Propinsi Kalimantan Barat 2000. Laporan Tahunan Dinas Kehutanan Propinsi Kalimantan Barat 1999/2000. Pontianak, Kalbar, Indonesia.

Dinas Perkebunan Propinsi Kalimantan Barat 1993. Perkebunan Kalimantan Barat dalam Angka Tahun 1992. Pontianak, Kalbar, Indonesia.

Dinas Perkebunan Propinsi Kalimantan Barat 1996. Perkebunan Kalimantan Barat dalam Angka Tahun 1995. Pontianak, Kalbar, Indonesia.

Dinas Perkebunan Propinsi Kalimantan Barat 1999. Perkebunan Kalimantan Barat dalam Angka tahun 1998. Pontianak, Kalbar, Indonesia.

Dinas Perkebunan Propinsi Kalimantan Barat 2000. Perkebunan Kalimantan Barat dalam Angka 1999. Pontianak, Kalbar, Indonesia.

Dinas Perkebunan Propinsi Kalimantan Barat 2000. Informasi Pencapaian dan Perkembangan Pembangunan Perkebunan di Propinsi Kalimantan Barat. Pontianak, Kalbar, Indonesia.

Dinas Perkebunan Propinsi Kalimantan Barat 2000. Informasi Pencapaian dan Perkembangan Pembangunan Perkebunan di Propinsi Kalimantan Barat. Pontianak, Kalbar, Indonesia.

Dinas Perkebunan Propinsi Kalimantan Barat 2000. Perkembangan Pemanfaatan lahan Perkebunan Besar di Propinsi Kalimantan Barat s/d Desember 1999. Pontianak, Kalbar, Indonesia.

Dinas Pendapatan Kabupaten Ketapang 2000. Laporan Pendapatan Daerah Bulan Maret 1996 - Maret 2000. Ketapang, Kalbar, Indonesia.

Ditjen Bina Program Dirjen Kehutanan Departemen Pertanian 1971. Survey Kelompok Hutan Laporan No. 269 dan 245.

Forum Komunikasi dan Diskusi Masyarakat Ketapang 2000.Pemberdayaan Potensi Daerah Ketapang Menyongsong Otonomi Daerah Tahun 2001.

Harian Equator edisi Jum'at 25 Juni 1999 “Silva Tuding Aparat Ikut Rambah Gunung Palung.

H. Rousdy Said 2000. Analisis Masalah Kebijakan Pengelolaan SDA di Kawasan TNGP. Dialog
Kebijakan. Juni 2000. Ketapang.

Hermany Hasyim 2000. TNGP: Kondisi, Potensi, Masalahnya dan Bagaimana Pengelolaannya. Dialog Kebijakan. Juni 2000. Ketapang.

Hery Christiyono 2000. Realitas Masalah Pengamanan Sumberdaya Alam TNGP. Dialog Kebijakan. Juni 2000. Ketapang

J.U. Lontan 1975. Sejarah Hukum Adat dan Adat Istiadat Kalimantan Barat. Edisi I, 1975. Pemda Tingkat I Kalbar.

Kanwil Kehutanan dan Perkebunan Propinsi Kalimantan Barat. 1999. Statistik Kehutanan dan Perkebunan Propinsi Kalimantan Barat 1997/1998. Pontianak, Kalbar, Indonesia.

Kanwil Kehutanan dan Perkebunan Propinsi Kalimantan Barat. 1999. Laporan Tahunan Periode tahun 1998/1999. Pontianak, Kalbar, Indonesia.

Kanwil Kehutanan dan Perkebunan Propinsi Kalimantan Barat. 2000.Statistik Kehutanan dan Perkebunan Propinsi Kalimantan Barat 1998/1999.

Kanwil Deperindag Propinsi Kalbar 1998. Profil Industri Hasil Pertanian dan Kehutanan Daerah Kalimantan Barat (Industri yang Aktif) tahun 1998. Pontianak, Kalbar, Indonesia.

KPH Ketapang Laporan Tahunan Kesatuan Pemangkuan Hutan Ketapang Dinas Kehutanan Kalbar 1990/1991. Ketapang.

KPH Ketapang Laporan Tahunan Kesatuan Pemangkuan Hutan Ketapang Dinas Kehutanan Kalbar 1992/1993. Ketapang.

KPH Ketapang Laporan Tahunan Kesatuan Pemangkuan Hutan Ketapang Dinas Kehutanan Kalbar 1994/1995. Ketapang.

KPH Ketapang Laporan Tahunan Kesatuan Pemangkuan Hutan Ketapang Dinas Kehutanan Kalbar 1996/1997. Ketapang.

KPH Ketapang 1999. Laporan Tahunan Kesatuan Pemangkuan Hutan Ketapang Dinas Kehutanan Kalbar 1998/1999. Ketapang

KPH Ketapang 2000. Daftar IPKH dan sawmill yang Berada di Wilayah KPH Ketapang. Ketapang, Kalbar, Indonesia.

LTFE Gunung Palung 2000. Laporan Resmi Proyek Hutan Kemasyarakatan Gunung Palung tentang Pembakaran Camp. Lubuk Kuali, Ketapang, Kalbar, Indonesia.

MT Gede Pangrango National Park 1996. Information Book Series Vol 2.

Nico Andasputra 1999. Perlawanan Rakyat di 
Hutan kalimantan : kumpulan berita tentang perlawanan Masyarakat Adat terhadap HPH, HTI dan Pertambangan. Institut Dayakologi, Pontianak, Kalbar.

Paulus Florus dan Edi Petebang 1999. Panen Bencana Kelapa Sawit. Institut Dayakologi, Pontianak, Kalbar.

Pemerintah Propinsi Daerah Tingkat I Kalimantan Barat 1992. Rencana Struktur Tata Ruang Propinsi Kalimantan Barat Tahun 2005. Pontianak, Kalbar, Indonesia.

Pemerintah Propinsi Daerah Tingkat I Kalimantan Barat 1989. Sejarah Singkat Perkembangan Pemerintahan Daerah Tingkat I Kalimantan Barat 1957 - 1988. Pontianak, Kalbar, Indonesia.

Pemerintah Propinsi Daerah Tingkat I Kalimantan Barat 1988. Memori Gubernur KDH TK I Kalbar Haji Soedjiman Masa Bakti 1983-1988. Pontianak, Kalbar, Indonesia.

Pemerintah Propinsi Daerah Tingkat I Kalimantan Barat 1993. Memori Gubernur KDH TK I Kalbar Parjoko Suryokusumo Masa Bakti 1988-1993. Pontianak, Kalbar, Indonesia.

Pemerintah Propinsi Kalimantan Barat 2000. Pertanggung Jawaban Gubernur Kalimantan Barat Tahun Anggran 1999/2000 Bidang Desentralisasi pada Rapat Paripurna DPRD Propinsi Kalimantan Barat 14 Juni 2000. Pontianak, Kalbar, Indonesia.

Pemerintah Kabupaten Daerah Tingkat II Ketapang 1998. Memori Bupati KDH TK II Ketapang Drs. H. Soenardi Basnu Masa Bakti 1993-1998. Ketapang, Kalbar, Indonesia.

SBKSDA, Kanwilhut kalbar 1998.Rencana Pengelolaan TNGP Kalbar Buku II (Data,
Proyeksi dan Analisis). Proyek Pengembangan Kawasan Konservasi Kalbar tahun anggaran 1996/1997. Pontianak Maret 1998.

SBKSDA, Kanwilhut kalbar. Rencana Pengelolaan TNGP Kalbar Buku III (Rencana Tapak). Proyek Pengembangan Kawasan Konservasi Kalbar tahun anggaran 1996/1997. Pontianak Maret 1998.

Sesep Zainuddin 2000. Strategi Transformasi Kebijakan Pengelolaan SDA di Kawasan TNGP. Dialog Kebijakan. Juni 2000. Ketapang. Stepanus Djuweng 1996. Orang Dayak, Pembangunan dan Agama Resmi

Tim Penataan Kelembagaan Terpadu Kabupaten Ketapang 2000. Daftar Inventaris Kewenangan Kabupaten Ketapang Kalimantan Barat(bahan pembahasan pada rapat kerja penyusunan pedoman kewenangan Kabupaten/Kota pada tanggal 10 Juli 2000 di Jakarta)

Tim Peneliti Sosial Ekonomi Laboratorium Ekologi Hutan Tropis Universitas Harvard 1998. Data Dasar Keadaan Sosial Ekonomi Masyarakat yang Akan Berpartisipasi Dalam Proyek Percontohan Pengelolan Hutan Oleh masyarakat di daerah Penyangga TNGP Propinsi Kalbar. Pontianak, Kalbar, Indonesia.

UPT TNGP 2000. Kondisi Umum TNGP. Lokakarya Pengelolaan Daerah Penyangga TNGP. April 2000. Ketapang.

Yuyun Kurniawan 2000. Menyingkap Tabir Seputar Konflik Pengelolaan TNGP. Dialog Kebijakan. Juni 2000. Ketapang.

Zainuddin 2000. Analisis Masalah Kebijakan Pengelolaan SDA di Kawasan TNGP. Dialog Kebijakan. 30 Juni 2000. Ketapang. 
